\title{
The Triassic-Jurassic Fundy Basin, eastern Canada: regional setting, stratigraphy and hydrocarbon potential
}

\author{
John A. Wade1, David E. Brown ${ }^{2}$, Alfred Traverse ${ }^{3}$ and Robert A. Fensome ${ }^{1}$ \\ 1 Geological Survey of Canada (Atlantic), P.O. Box 1006, Dartmouth, Nova Scotia B2Y 4A2, Canada \\ ${ }^{2}$ Canada-Nova Scotia Offshore Petroleum Board, \\ 1791 Barrington Street, Halifax, Nova Scotia B3J 3K9, Canada \\ ${ }^{3}$ Department of Geosciences, Pennsylvania State University, \\ University Park, Pennsylvania 16802, U.S.A.
}

Date Received May 26, 1995

Date Accepted March 4, 1996

\begin{abstract}
Fundy Basin, one of a series of half graben that formed along the eastern margin of North America during the Triassic/Jurassic rifting of Pangaea, lies mainly to the south of the Cobequid-Chedabucto Fault System in Nova Scotia and beneath the Bay of Fundy. Continental red clastic rocks and basalt flows of the Triassic and Early Jurassic Newark Supergroup crop out continuously along the Bay of Fundy and Minas Basin coast of Nova Scotia and at several sites in southern New Brunswick. These units thicken beneath the waters of the bay to a presentday maximum of nearly $10 \mathrm{~km}$. Proximal facies preserved along the faulted New Brunswick margin of the basin consist of upper alluvial fan and fluvial clastics which grade laterally into sheet flood deposits. Along the gently north-dipping Nova Scotia margin, facies consist of distal alluvial fan, sheet flood and playa mud flat deposits.

Facies projections suggest the probability that petroleum-generating lacustrine sequences are widespread along the basin axis. In the Wolfville Formation and lower part of the Blomidon Formation these may be overmature but the upper part of the Blomidon Formation and the Scots Bay Formation have the potential for appreciable quantities of hydrocarbons.
\end{abstract}

Le bassin de Fundy, l'un des demi-grabens d'une série qui s'est formée le long de la marge continentale de l'Amérique du Nord lors de la séparation triasique-jurassique de la Pangée, est principalement situé au sud du système de failles de Cobequid-Chedabucto, en Nouvelle-Écosse, ainsi qu'au-dessous de la baie de Fundy. Des écoulements de basaltes et de roches clastiques rouges continentales du supergroupe du Trias et du Jurassique inférieur de Newark affleurent de façon continue le long de la baie de Fundy et de la côte du bassin de Minas en Nouvelle-Écosse ainsi qu'en plusieurs endroits dans le sud du Nouveau-Brunswick. Ces unités s'épaississent audessous des eaux de la baie jusqu'à un maximum actuel de près de $10 \mathrm{~km}$. Les faciès proximaux conservés le long de la marge faillée néo-brunswickoise du bassin sont constitués de cônes alluviaux supérieurs et de roches détritiques fluviales qui passent latéralement à des gîtes d'inondation en nappes. Le long de la marge doucement inclinée vers le nord néo-écossaise, les faciès sont constitués de cônes alluviaux distaux, de gîtes d'inondation en nappes et de playas de slikkes.

Les projections des faciès permettent de supposer qu'il est probable que les séquences lacustres sont répandues le long de l'axe du bassin. Celles-ci pourraient être immatures dans la Formation de Wolfville et la partie inférieure de la Formation de Blomidon, mais la partie supérieure de la Formation de Blomidon et la Formation de Scots Bay offrent un potentiel de quantités appréciables d'hydrocarbures.

[Traduit par la rédaction]

\section{INTRODUCTION}

The development of Mesozoic sedimentary basins along the eastern margin of North America has now been firmly tied to the breakup of Pangaea. Rifting of the central part of Pangaea during Mid and Late Triassic time resulted in the formation of a series of half graben extending (on the presentday North American margin) from Florida to The Grand Banks of Newfoundland. Many of these, such as the Newark and Hartford basins in the U.S.A., are onshore and are well studied (e.g., Maclure, 1817; Hitchcock, 1823; Russell, 1878, 1880; Gratacap, 1886; Darton, 1889; Van Houten, 1964; Manspeizer and Olsen, 1981; and many others, e.g., in Margolis et al., 1986), whereas other basins, particularly those in the offshore, are poorly known. One of the latter, Fundy Basin, has an area of about $16,500 \mathrm{~km}^{2}$, which lies mainly to the south of the Cobequid-Chedabucto Fault System in Nova Scotia and beneath the Bay of Fundy. Other poorly known basins, covering $5000+\mathrm{km}^{2}$, that may have been contiguous with Fundy Basin occur to the southwest. From studies of peripheral outcrops, rocks in the Fundy Basin have long been recognized as related to the Triassic-Jurassic Newark Supergroup. However, until recently, little has been published on the extensive Mesozoic sedimentary section resident beneath the waters of the Bay of Fundy (Swift and Lyall, 1968; Brown, 1986). 
Geologic mapping onshore, study of offshore seismic and well data, and new paleontological discoveries have extended the geographic distribution of Mesozoic strata in the Bay of Fundy region and have stretched the age range of these sediments from the Mid Triassic Anisian (Baird and Olsen, 1983; Olsen, 1988a; Olsen et al., 1989), or Ladinian, (Nadon and Middleton, 1985 ) to at least the early Mid Jurassic. This paper will further demonstrate that the present tripartite configuration of the basin is the result of regional ?Late Jurassic to Early Cretaceous tectonic adjustment and not sedimentation into individual depocentres.

Many names have been introduced for the Mesozoic sedimentary basin centred in the Bay of Fundy region. Dawson (1855) referred to it as the Acadian Trough and Poole et al. (1970) called it Cape Split Trough. Jansa and Wade (1975a) named it Fundy Basin; Keppie (1977) used the term Bay of Fundy Aulacogene; Perkins (1981) recommended Bay of Fundy Basin; and Brown (1986) and Brown and Grantham (1992) also used Fundy Basin. Howie and Barss (1975) named the regional feature, extending from the Bay of Fundy to western Newfoundland, Fundy Epieugeosyncline. Brown (1986) introduced the name Chignecto Subbasin for the local depocentre beneath Chignecto Bay and Olsen et al. (1989) referred to the main depocentre beneath the Bay of Fundy as Fundy Subbasin and the smaller feature beneath Minas Basin as Minas Subbasin.

In this paper we follow the recent trend and refer to the Mesozoic basin and its contained strata as Fundy Basin. We also recognize the three interconnected post-depositional entities into which the basin has been formed, and agree that the main feature, centred beneath the western part of the bay, be termed Fundy Subbasin and the two ancillary features be the Minas Subbasin and Chignecto Subbasin. In addition, a fourth feature, located beneath Grand Manan Channel, is designated "Grand Manan Subbasin" (Fig. 1). Other poorly defined areas with accumulations of Triassic/Jurassic strata, extending out into the Gulf of Maine, eventually may be shown to be associated with the Fundy Basin, but are unnamed at this time.

Basins containing Newark-type synrift sediments are recognized as possible petroleum provinces with the potential for appreciable quantities of hydrocarbons (Manspeizer, 1981; Ziegler, 1983; Pratt and Burruss, 1988; Kruge et al., 1990). Petroleum exploration programs in the Bay of Fundy from 1968-75 and 1980-83 resulted in the acquisition of over $4600 \mathrm{~km}$ of variable quality seismic data and the drilling of two deep exploratory wells. These data, combined with published material and the study of outcrop sections in Nova Scotia and New Brunswick, provide the basis for our interpretation of the geological history and hydrocarbon potential of Fundy Basin.

Throughout this study, when the need for absolute age dating within the Mesozoic arose, the authors have used the time scale of Harland et al. (1990). Depending on the time scale used, differences of more than $16 \mathrm{Ma}$ occur at some Mesozoic stages (Table 1). It should be noted that signifi-

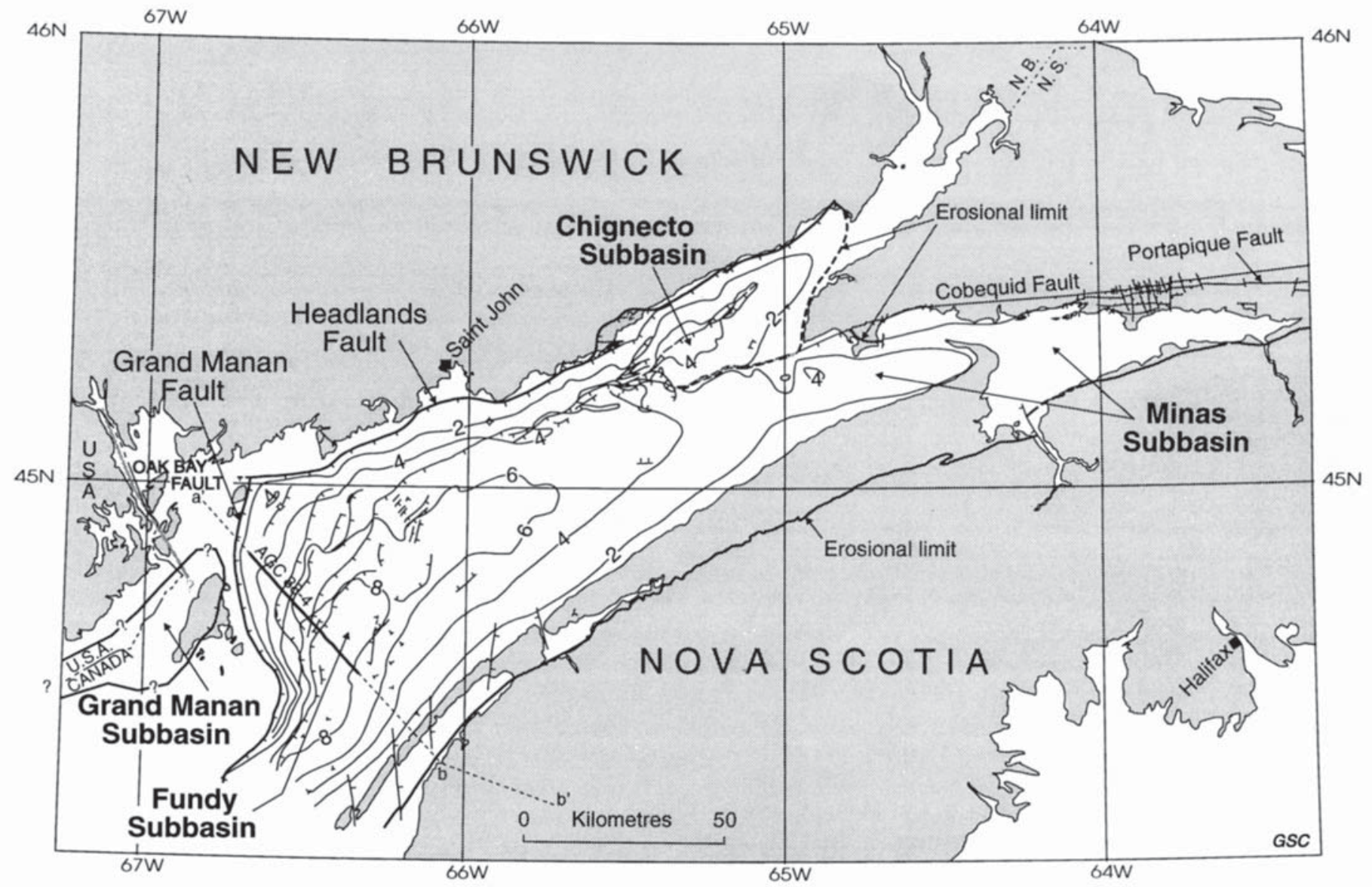

Fig. 1. Major tectonic elements of the Fundy Basin. Contours are subsea depth to the base of Mesozoic strata. a'-b' is line of section in Figure 5 . 
Table 1. A comparison of Triassic and Jurassic time scales.

\begin{tabular}{|c|c|c|c|c|c|}
\hline & $\begin{array}{c}\text { Harland } \\
\text { et al. } \\
1990\end{array}$ & $\begin{array}{c}\text { Gradstein } \\
\text { et al. } \\
1994\end{array}$ & $\begin{array}{l}\text { Haq } \\
\text { et al. } \\
1988\end{array}$ & $\begin{array}{c}\text { Elsevier } \\
1987\end{array}$ & $\begin{array}{c}\text { Palmer } \\
1983\end{array}$ \\
\hline Stage & \multicolumn{5}{|c|}{ Age at the end of the stage in Ma } \\
\hline Tithonian & 145.6 & 144.2 & 131.0 & 140.0 & 144.0 \\
\hline Kimmeridgian & 152.1 & 150.7 & 136.0 & 145.0 & 152.0 \\
\hline Oxfordian & 154.7 & 154.1 & 145.0 & 154.0 & 156.0 \\
\hline Callovian & 157.1 & 159.4 & 152.0 & 160.0 & 163.0 \\
\hline Bathonian & 161.3 & 164.4 & 157.0 & 166.0 & 169.0 \\
\hline Bajocian & 166.1 & 169.2 & 165.0 & 172.0 & 176.0 \\
\hline Aalenian & 173.5 & 176.5 & 171.0 & 177.0 & 183.0 \\
\hline Toarcian & 178.0 & 180.1 & 179.0 & 184.0 & 187.0 \\
\hline Pliensbachian & 187.0 & 189.6 & 186.0 & 189.0 & 193.0 \\
\hline Sinemurian & 194.5 & 195.3 & 194.0 & 196.0 & 198.0 \\
\hline Hettangian & 203.5 & 201.9 & 201.0 & 202.0 & 204.0 \\
\hline Norian & 208.0 & 205.7 & 210.0 & 210.0 & 208.0 \\
\hline Carnian & 223.4 & 220.7 & 223.0 & 226.0 & 225.0 \\
\hline Ladinian & 235.0 & 227.4 & 231.0 & 230.0 & 230.0 \\
\hline Anisian & 239.5 & 234.3 & 236.0 & 237.0 & 235.0 \\
\hline Scythian & 241.1 & 241.7 & 240.0 & 243.0 & 240.0 \\
\hline Permian & 245.0 & 248.2 & 248.0 & 250.0 & 245.0 \\
\hline
\end{tabular}

cant variations in attributes such as depositional rates will result from using different time scales.

\section{Regional Setting}

The early Mesozoic synrift continental basins of eastern North America closely follow the trend of the older compressional Appalachian Orogen (e.g., Manspeizer, 1988). These basins owe their development to the extensional reactivation of pre-existing thrust faults and ramps formed during the Variscan and earlier orogenies (Manspeizer, 1981; Petersen et al., 1984; Taylor and Resseter, 1985; Swanson, 1986; Schlische, 1993). The study of outcrop and seismic data show that Fundy Basin has been variably influenced by major, pre-existing transverse faults. Thus, an understanding of the geologic setting and tectonic history of the preMesozoic strata in the Bay of Fundy region is a necessary requirement in interpreting the evolution of Fundy Basin and the distribution and facies of the infilling strata.

Williams (1979) subdivided the northern Appalachians into five lithotectonic terranes or zones which were attributed to the final closing of the early Paleozoic Iapetus Ocean. These exotic terranes (Williams and Hatcher, 1982, 1983) are separated by major thrust and transverse faults. The metallogenesis, metamorphism, stratigraphy, plutonism and tectonism of each zone are distinctive. Fundy Basin occupies a half graben at the boundary between two of these zones, Avalon and Meguma (Fig. 2).

The Avalon Zone in southern New Brunswick and northern Nova Scotia is characterized by thick sequences of late Precambrian and early Paleozoic mafic volcanic and continental metasedimentary sequences representing volcanic arc-

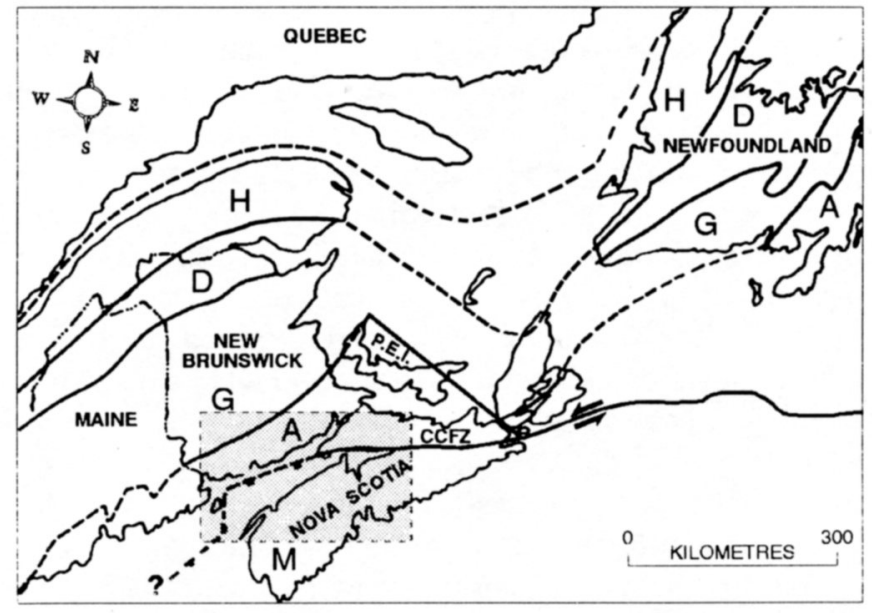

Fig. 2. Major Appalachian terranes after Williams (1979) and Barr and Raeside (1989). $H=$ Humber, $D=$ Dunnage, $G=$ Gander, $\mathrm{A}=$ Avalon, $\mathrm{M}=$ Meguma, $\mathrm{CCFZ}=$ Cobequid-Chedabucto Fault Zone. Arrows show relative movement during the early Mesozoic. Shaded rectangle is Fundy Basin study area.

related environments (Rast et al., 1976; Keppie, 1989). It is intruded by generally granitic plutons. In southern Nova Scotia and the adjacent continental shelf, the Meguma Zone is composed of the Cambro-Ordovician Meguma Group, a more than $7 \mathbf{~ k m}$ thick succession of metamorphosed, sanddominated, turbiditic flysch, the Goldenville Formation, and an overlying $3.5 \mathrm{~km}$ thick silty and shaly turbiditic flysch, the Halifax Formation (Schenk, 1991). In southwestern Nova Scotia, the Meguma Group is conformably overlain by up to $6 \mathrm{~km}$ of metasedimentary (paralic to shallow marine) and volcanic rocks of the Silurian White Rock, Kentville and New Caanan formations and up to $1.4 \mathrm{~km}$ of mildly metamorphosed Early Devonian shallow marine sandstone, siltstone, shale and minor limestone of the Torbrook Formation (Smitheringale, 1973). All sequences are cut by $\sim 370$ Ma peraluminous granitic intrusions of batholithic proportions (MacDonald et al., 1992).

Both zones have undergone several orogenic events. One of the most significant is the Acadian Orogeny, resulting, in this area, from dextral transpression between the Meguma and Avalon crustal blocks during the mid Paleozoic and causing regional deformation in the accreting Meguma block. The dominant structural features in the Meguma Zone are long, upright, northeast trending folds with dips on the anticlinal limbs often up to $80^{\circ}$. The metamorphic grade in the Meguma Group ranges from greenschist in the north and northeast to amphibolite in the southwest (Keppie and Muecke, 1979), possibly indicating greater subsequent uplift in the southwest. The base of the Meguma Group is interpreted as a decollement zone, named the Fundy decollement (Brown, 1986).

The magnitude of the unconformity due to the Acadian Orogeny is an enigma. Abundant stratigraphic and geochronologic data indicate that folding of the Meguma Zone strata, granitic intrusion, cooling, and subsequent unroofing of some 3 to $5 \mathrm{~km}$ of overburden all occurred within about $25 \mathrm{Ma}$ from approximately $385 \mathrm{Ma}$ (end of deposition of the ma- 
rine Torbrook Formation) to $360 \mathrm{Ma}$ (initiation of the onlapping terrestrial Horton Group in central Nova Scotia). This represents removal of up to $200 \mathrm{~mm}$ of crystalline rock per 1000 years. Had this rate of erosion continued, the entire Meguma Group might have been removed in another $50 \mathrm{Ma}$. Knowing that the facies overlying the Meguma Group represent the shallowing of dominantly marine depositional systems (e.g., flysch to shelf), R.J. Ryan, A.K. Chatterjee and P.K. Smith, (personal communication, 1994) speculate that the rapid removal of sedimentary strata over such a short time interval might be accommodated if the missing material was dominated by carbonate facies and was removed by chemical erosion. The elegance of this theory is that the erosion would leave little or no trace of these sediments.

Within about $10 \mathrm{Ma}$ of their emplacement the $370 \mathrm{Ma}$ granites, as well as the enclosing folded and deeply eroded Cambro-Ordovician Meguma Group siliciclastics, were overlain unconformably by Late Devonian/Early Carboniferous (Famennian and Tournaisian) clastics of the Horton Group (M.S. Barss, personal communication, 1990; Martel et al., 1993). The general lack of chilled margins between the granites and host rocks make it difficult to establish the amount of erosion of granite before deposition of Carboniferous cover (e.g., MacDonald and Horne, 1988). The detritus, eroded during the Mid and Late Devonian, probably was transported to the north and east and deposited in the newly formed Carboniferous rift basins as clastic units within the Fountain Lake Group/Falls Formation and the lowermost Horton Group. Also, a significant proportion of this sediment may have been assimilated or overridden in the final stages of Acadian thrust faulting. Paradoxically, in spite of being almost continuously emergent and elevated in the $250 \mathrm{Ma}$ since the late Paleozoic/early Mesozoic, there has been proportionally minimal erosion of Meguma Zone strata. Upper Paleozoic strata underlie the Mesozoic formations in the eastern part of Fundy Basin but are unknown in the western part of the area where erosion has been the greatest.

In northern Nova Scotia, the Avalon and Meguma zones are separated by a major transverse fault system (Fig. 2) most commonly referred to as the Cobequid-Chedabucto Fault System (Webb, 1969). On the premise that the Meguma Zone consists of early Paleozoic metasedimentary rocks, granitic batholiths and a pre-Meguma Group basement complex, we have mapped the westward extension of the bounding CobequidChedabucto Fault System from the seismic data as extending from near Cape Chignecto, Nova Scotia, to just south of Point Lepreau, New Brunswick, thus establishing the Avalon/ Meguma boundary beneath the Bay of Fundy (Figs. 3, 4, 5). Along the New Brunswick coast, the fault zone includes the extension of the thrust faults of the Variscan Front described by Belt (1968), Rast et al. (1978), Rast (1883), Plint and van de Poll (1984), Nance (1986, 1987), McCutcheon and Robinson (1987), Keppie (1989), and others, and confirms the premise by Rast and Grant (1973) that they connect to the Chedabucto Fault.

The Cobequid-Chedabucto Fault System has a complex history of movement. Detailed studies indicate a protracted history of dextral strike slip motion (Mawer and White, 1987). Keppie (1982) inferred that about $75 \mathrm{~km}$ of sinistral movement occurred on this fault system from the Mid Triassic to the Cretaceous during formation of the Fundy Basin. Our interpretation of the reflection seismic data support the concept of some early Mesozoic sinistral movement in conjunction with down-to-the-southeast normal movement. However, as described below, as there are two intersecting basin-bounding faults, only about $10 \mathrm{~km}$ of horizontal movement is required to effect opening of the Fundy Rift. This is in agreement with models published by Schlische (1991).

The nature and attitude of the fault surface between the Avalon and Meguma zones changes from east to west. In outcrop north of Minas Channel, the western portion of the Cobequid Fault dips south at about $85^{\circ}$ (Donohoe and Wallace, 1982). The westward projection of this fault shows well on the seismic data from the Bay of Fundy. However, it must be remembered that the current aspect of the fault is post-depositional, probably related to a transpressional phase associated with Late Jurassic to Early Cretaceous tectonic events which affected the Scotian Basin (Wade and MacLean, 1990, Ravenhurst et al., 1990). Adjacent to Cape Chignecto, the fault zone exhibits features characteristic of major strikeslip such as positive and negative flower structures, reverse faults, and related anticlinal and synclinal structures (Harding, 1985). Further west, where the original movement was more transtensional, the fault has a low-angle normal mode, dipping south-southeast. In this area the fault sole can be seen on seismic sections to depths of $20 \mathrm{~km}$ or more (Figs. 4, 5) and it is interpreted as the boundary between the Avalon and Meguma zones (Keen et al., 1991). Here, the late transpression phase reversed the motion on the low-angle normal faults resulting in the formation of anticlinal structures along the northern flank of the basin (Withjack et al., 1992).

The collision and accretion of the Meguma and Avalon zones in the ?Mid Devonian raises the question of the existence of an associated subduction zone. A subduction zone would be consistent with the Meguma Zone representing an exotic block from the northwestern margin of Gondwana. From the overthrust relationship, observed on seismic profiles between the Meguma and Avalon zones beneath the Bay of Fundy and Nova Scotia, we interpret that if a subduction zone occurred it must have been located southeast of Nova Scotia. A northwestward dipping subduction zone might best explain the Meguma style of folding with the lower pre-Meguma crust forming part of the subducting slab and the Meguma Group and other early Paleozoic strata compressing against and overriding rocks of the Avalon Zone. We would place the subduction zone southeast of Nova Scotia, maybe as far as the outer shelf, where Keen et al. (1991) hypothesized an upper mantle reflection as possibly emanating from the remnant of a subducted Paleozoic slab. This feature is demonstrated beneath SP 1200 on the right side of Figure 6. 


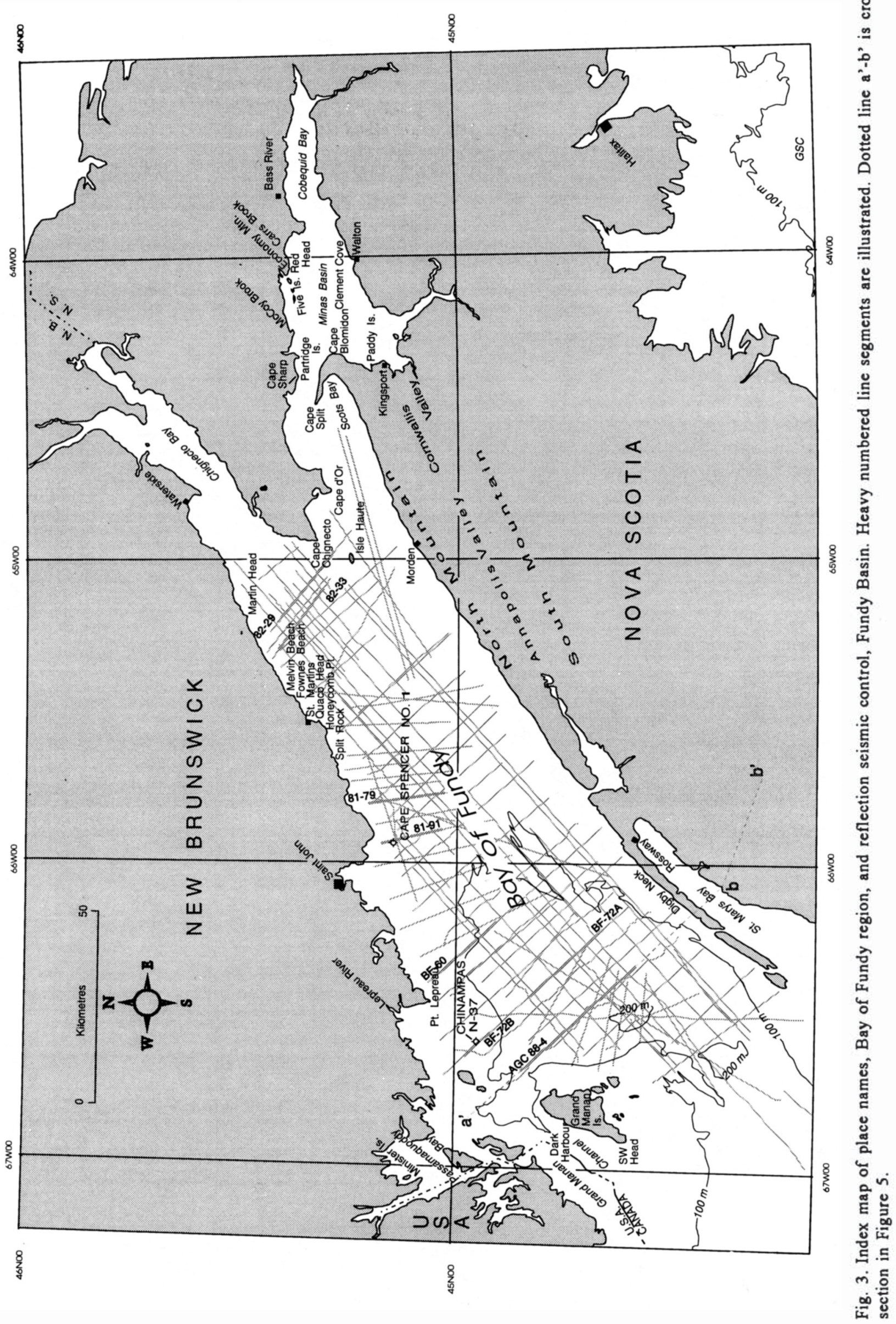




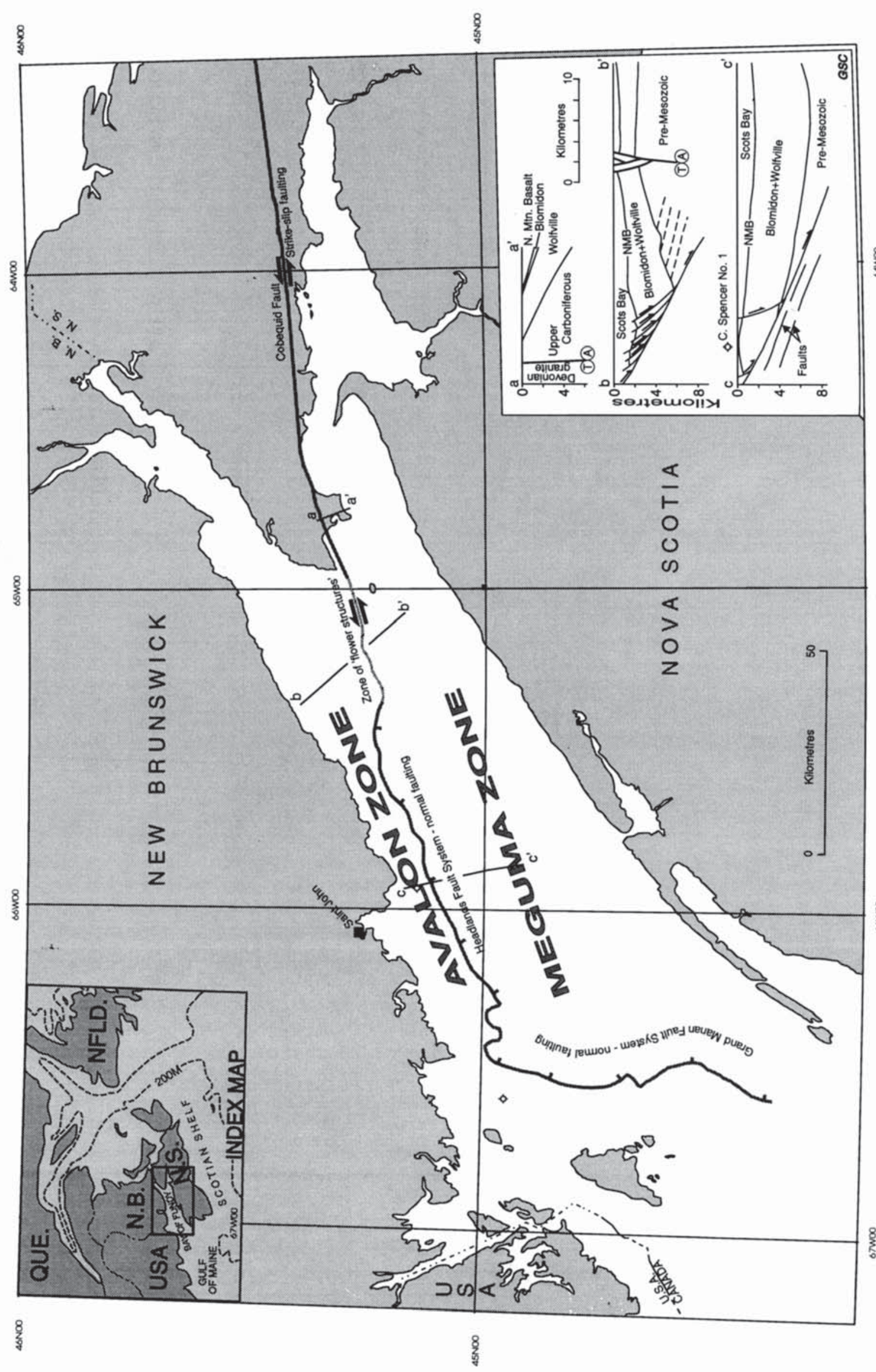

गे 


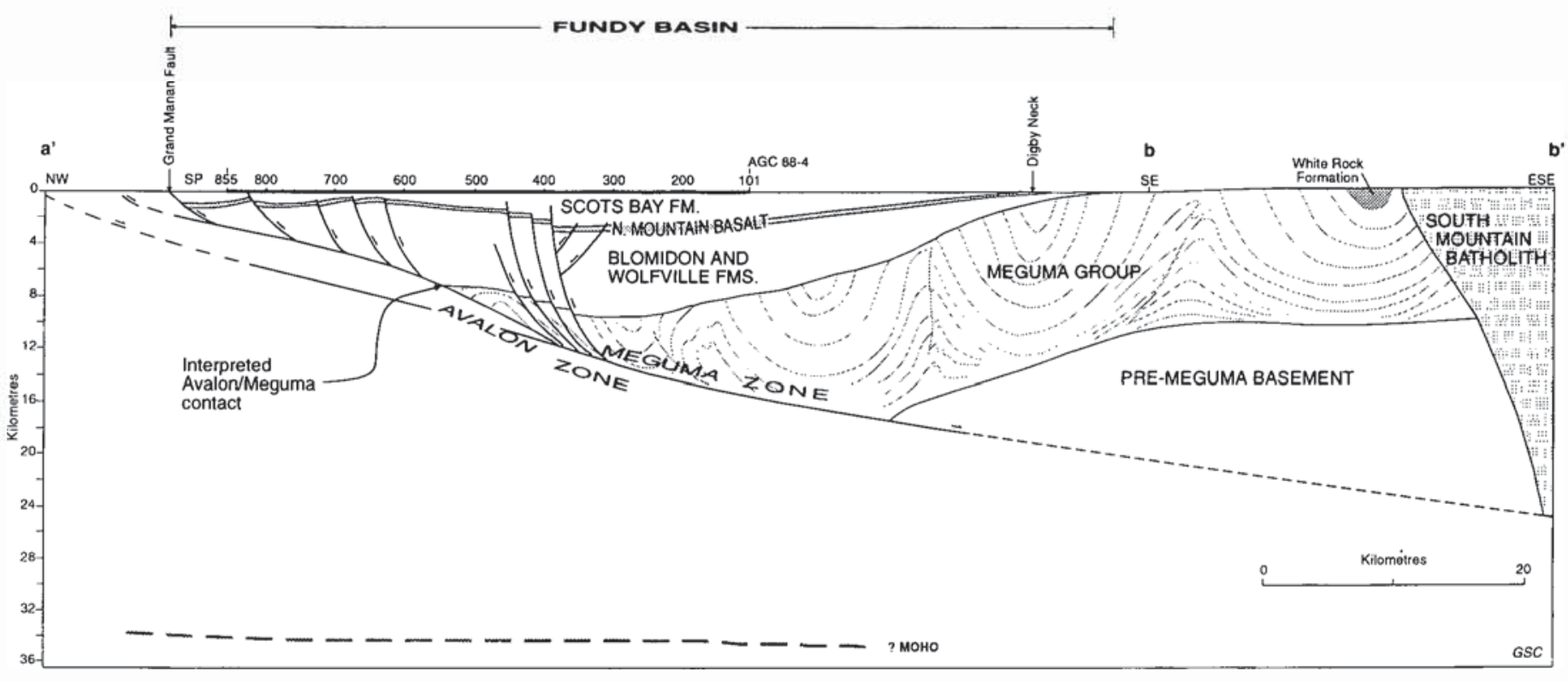

Fig. 5. Structural cross section a'-b' based on line AGC $88-4$ and other seismic and geological data. V.E. = $\sim 1: 1$. For location see Figure 1.

\section{SynRIFT MESOZOIC HISTORY}

By the early Mesozoic, compressional forces associated with the closing of Iapetus were replaced by extensional forces associated with the breakup of Pangaea. The Fundy rift system formed during Early to Mid Triassic as a result of sinistral and tensional reactivation of the dextral transform fault system that earlier juxtaposed Meguma and Avalon zones during the Siluro-Devonian (Acadian) and Permo-Carboniferous (Variscan) orogenies. These same extensional forces resulted in the development of a number of other generally northeast trending rift basins beneath the present day Scotian Shelf and Slope, also probably formed along pre-existing zones of weakness (Jansa and Wade 1975a, 1975b; Wade and MacLean, 1990) (Fig. 6).

In cross section, the early Mesozoic rift basins show a series of major normal faults on the footwall side, generally referred to as the border fault system, movement on which was largely responsible for the formation of the basin. The opposite, gently sloping hanging wall basement surface is termed the ramping margin (Schlische, 1993). The longitudinal profiles reveal these basins to be gently synclinal.

Fundy Basin developed within the broad valley incised along the Avalon/Meguma suture zone. In the study area the average elevation of the valley floor is interpreted to have been no more than a kilometre above sea level. However, highlands surrounding the basin probably reached 4 to $5 \mathrm{~km}$ above sea level. These figures are consistent with estimates derived by Hay et al. (1982) for the effects of topography on the paleoclimate of the North America/Africa rift system. Within the basin itself, relief was minimal, except near the border fault system where it periodically may have been a few hundred metres.

Interpretations of the paleogeography of Pangaea during the Triassic indicate that Fundy Basin was located very near the paleoequator with the paleopole at $\sim 50$ to $60^{\circ} \mathrm{N}$, $\sim 95$ to $105^{\circ} \mathrm{E}$ (Witte et al., 1991; van der Voo, 1988; van der Voo et al., 1984). Given the basin's position near the centre of a continent which extended from $85^{\circ} \mathrm{N}$ to $90^{\circ} \mathrm{S}$ latitude, the influence of the paleoclimate was profound. Interpretations of paleoclimate during this time range from arid, subtropical to humid, monsoon (e.g., Hubert and Forlenza, 1988; Smoot and Olsen, 1988; Hay et al., 1982; Hubert and Hyde, 1982; Klein, 1954, 1962). The oxidized nature of the marginal facies in Fundy Basin, together with their continental origins, interpreted large volume of sediment and moderate sedimentation rates, combine to indicate a generally hot and semi-arid climate with periodic and/or seasonal heavy rainfall and subsequent high fluvial discharge.

Four formations fill Fundy Basin. In ascending order these are Wolfville, Blomidon, North Mountain Basalt and Scots Bay (Fig. 7). Based on the occurrence and characteristics of paleosols in the sedimentary formations, Tanner (1993) interpreted semi-arid to subhumid conditions during the deposition of the Wolfville Formation; a semi-arid to arid paleoclimate for the Blomidon Formation; and a semiarid to subhumid climate for the Scots Bay Formation. The occurrence of at least two intervals with significant eolian deposits may indicate short periods of increased aridity.

This interpreted paleoclimatic trend contrasts somewhat with the hot and arid conditions which must have prevailed during deposition of the thick salt beds in the partly coeval Osprey and Argo formations in the Scotian Basin some 300 $\mathrm{km}$ to the east (Wade and MacLean, 1990). These salt deposits formed at, or below, sea level whereas Fundy Basin was at an interpreted elevation of less than $1 \mathrm{~km}$ with adjacent mountains reaching about 4 to $5 \mathrm{~km}$ above sea level.

Although possibly harsh, the climatic conditions in the study area were favourable for the existence of a variety of plant and animal life. Fossil plant material is common to 


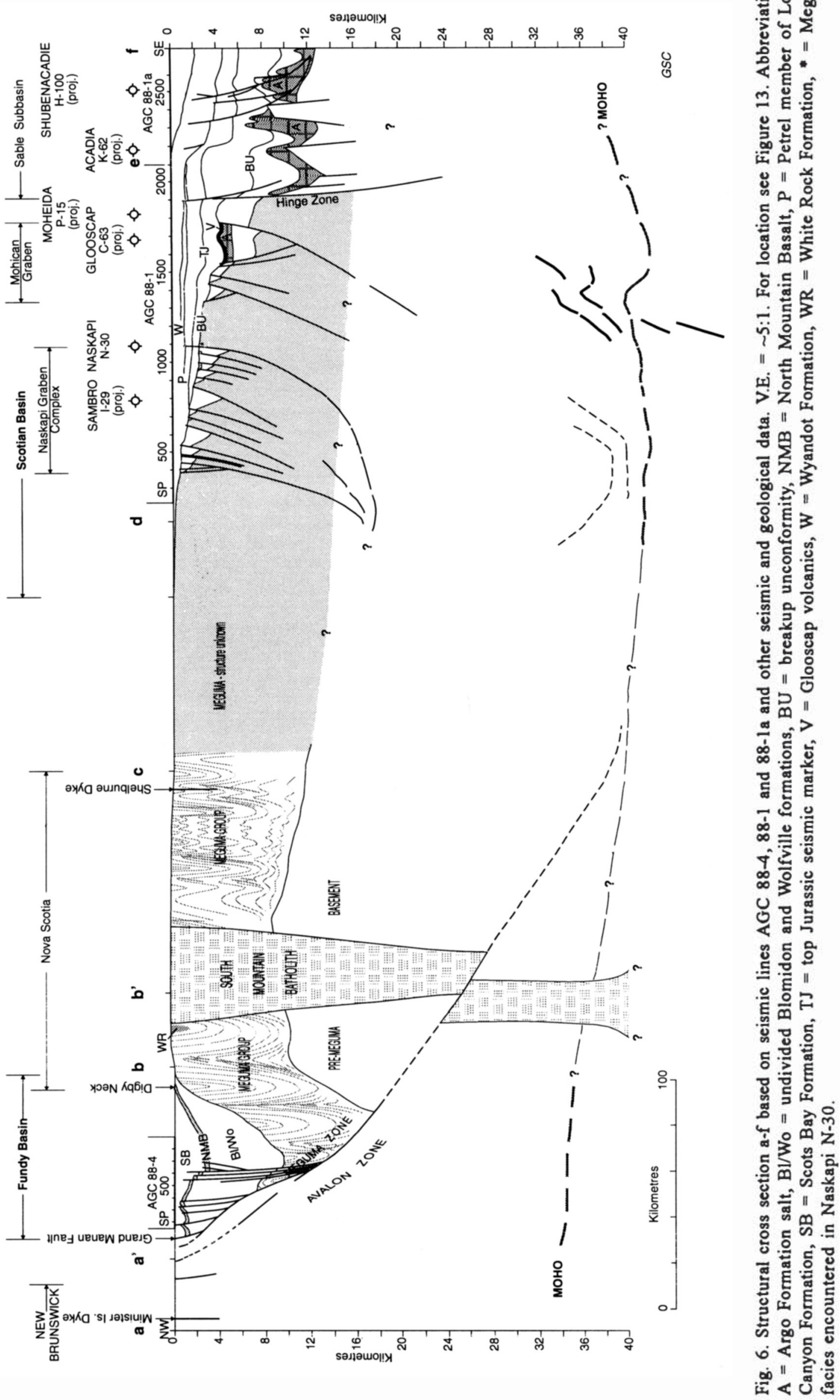




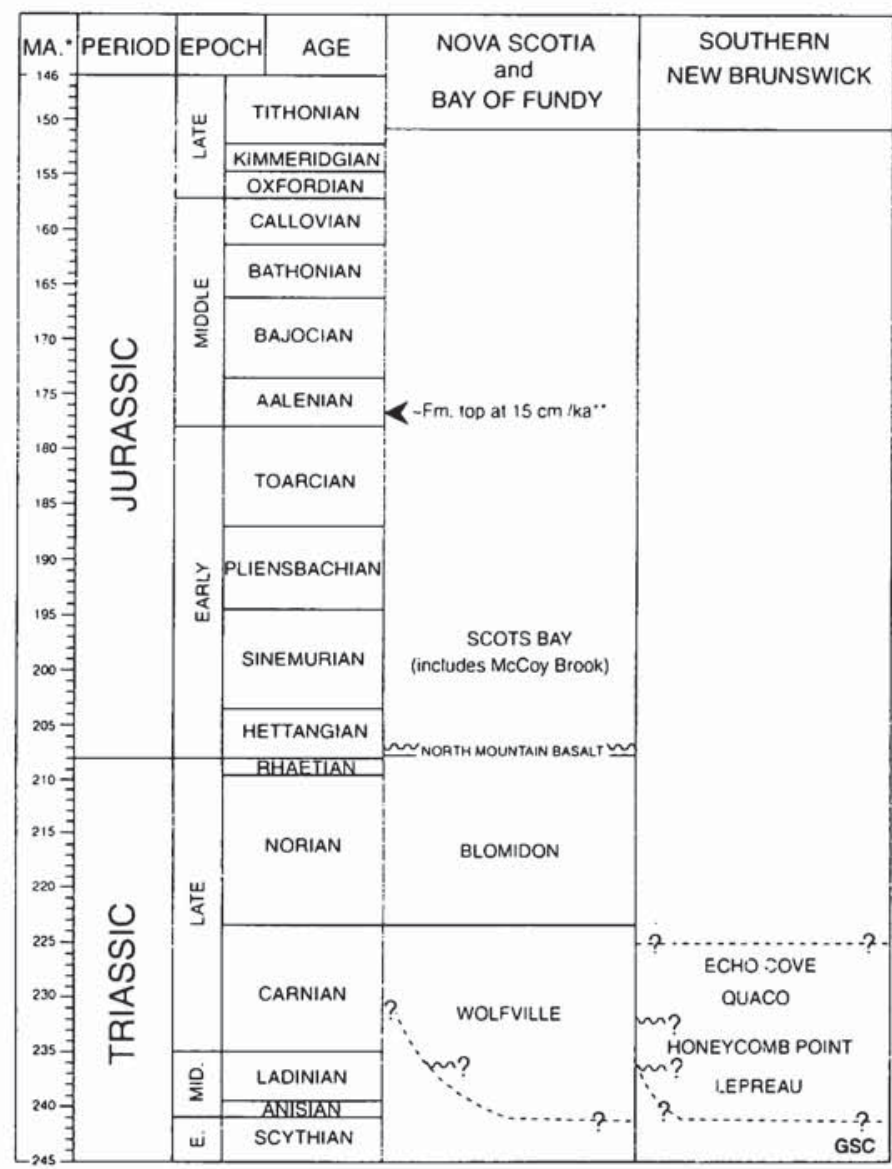

Fig. 7. Generalized stratigraphic column, Mesozoic formations, Fundy Basin. *Time scale after Harland et al., 1990. *Based on a maximum of $4.5 \mathrm{~km}$ of Scots Bay strata.

abundant in many areas, and ranges from large leaf and stem impressions and $\log$ casts to coaly partings, plant fragments and root casts. Remains of both herbivorous and carnivorous reptiles are locally common. Trace fossils and a variety of fresh water fishes and invertebrates attest to somewhat humid rather than more arid conditions. Olsen (1988a) described in some detail the varieties of fossils found in the various depositional environments of the Late Triassic-Early Jurassic rift system in eastern North America including numerous examples from Fundy Basin. Although fossil-rich deep lacustrine facies are not exposed onshore, analysis of seismic and outcrop facies imply that they will occur in some of the offshore depocentres.

Thus, it can be concluded from the variety of plant and animal remains that a vibrant ecosystem existed and perhaps flourished in spite of the somewhat stressful prevailing climatic and environmental conditions.

\section{Structural Features}

The early Mesozoic rift basins of eastern North America range in area from a few $\mathrm{km}^{2}$ to over $16,000 \mathrm{~km}^{2}$ (Fundy Basin). The hinge line for these basins tends to be unfaulted, although minor faults occur and slightly deform the dipping basement surface of the ramping margin. These rift basins are observed to have along-strike linkage via the same border fault system, with the system existing on the same side for all connected basins. This is true also for the subbasins of the Fundy Basin. The main faults bounding the northern margin of Minas Subbasin are the Cobequid, Portapique and Riversdale faults (Figs. 1, 8) (Donohoe and Wallace, 1982). As described earlier, the Cobequid Fault can be extended west southwestward beneath the Bay of Fundy to about $65^{\circ} 30^{\prime} \mathrm{W}$, $45^{\circ} 14^{\prime} \mathrm{N}$, where it connects with a complex of northeasttrending, southeast-dipping normal faults. The most northerly of these, which intersect Triassic/Jurassic strata, are herein referred to as the Headlands Fault System, so named because their subcrop parallels the high relief headlands of the southern coast of New Brunswick (Fig. 1). As shown in Figure 4 (inset sections b-b' and c-c') and Figures 5, 9, 10, 11 and 12, the faults of the Headlands System sole together in the subsurface and may extend to mid-crustal levels. They form the border fault system for the Fundy and Chignecto subbasins.

The relationship of these faults to the variety of northeast-trending thrusts cutting the pre-Mesozoic sequences in southern New Brunswick is not known. However, from the projection of the deep fault surfaces seen on the seismic profiles, many of them must crop out in New Brunswick and thus must be connected. Because the Cobequid Fault is the boundary between the Avalon and Meguma zones it is assumed that the Headlands Fault System, southwest of the junction described above, serves to separate these zones beneath the Bay of Fundy (Fig. 4).

The western side of Fundy Basin is controlled by a system of down-to-the-east normal faults, herein referred to as the Grand Manan Fault System (Figs. 1, 5, 6). It probably originated from the sinistral shear which opened the basin in the Early to Mid Triassic. This fault is subparallel to the Oak Bay Fault of McCutcheon and Robinson (1987) (Fig. 1) and might be interpreted to represent a sinistral offset of that fault by the Headlands Fault System. However, as there is no expression of the Oak Bay Fault on the Bay of Fundy seismic data, and it is not seen cutting the early Paleozoic rocks of eastern Grand Manan Island (Stringer and Pajari, Jr., 1981) it is unlikely that it occurs as far to the southeast as interpreted by McCutcheon and Robinson (1987, fig. 2). The Grand Manan Fault was active at least through the Early Jurassic, but the Early Jurassic Minister Island Dyke shows no displacement where it crosses the Oak Bay Fault, even though several kilometres to the east the dyke is offset by later faulting (Stringer and Burke, 1985). Therefore, we conclude that the Oak Bay and Grand Manan faults are not the same. The Grand Manan Fault lies entirely in the subsurface to the east of Grand Manan Island. South of Grand Manan, Fundy Basin narrows as it trends southwestward toward the Gulf of Maine. Here, the major, south-dipping normal fault indicated on the sparse seismic lines (Figs. 1, 3,8) is roughly parallel to, but considerably south of, the western extension of the Bellisle Fault as mapped by McCutcheon and Robinson (1987).

A regional cross section from the mouth of Passamaquoddy Bay, southern New Brunswick, across Fundy Basin, main- 


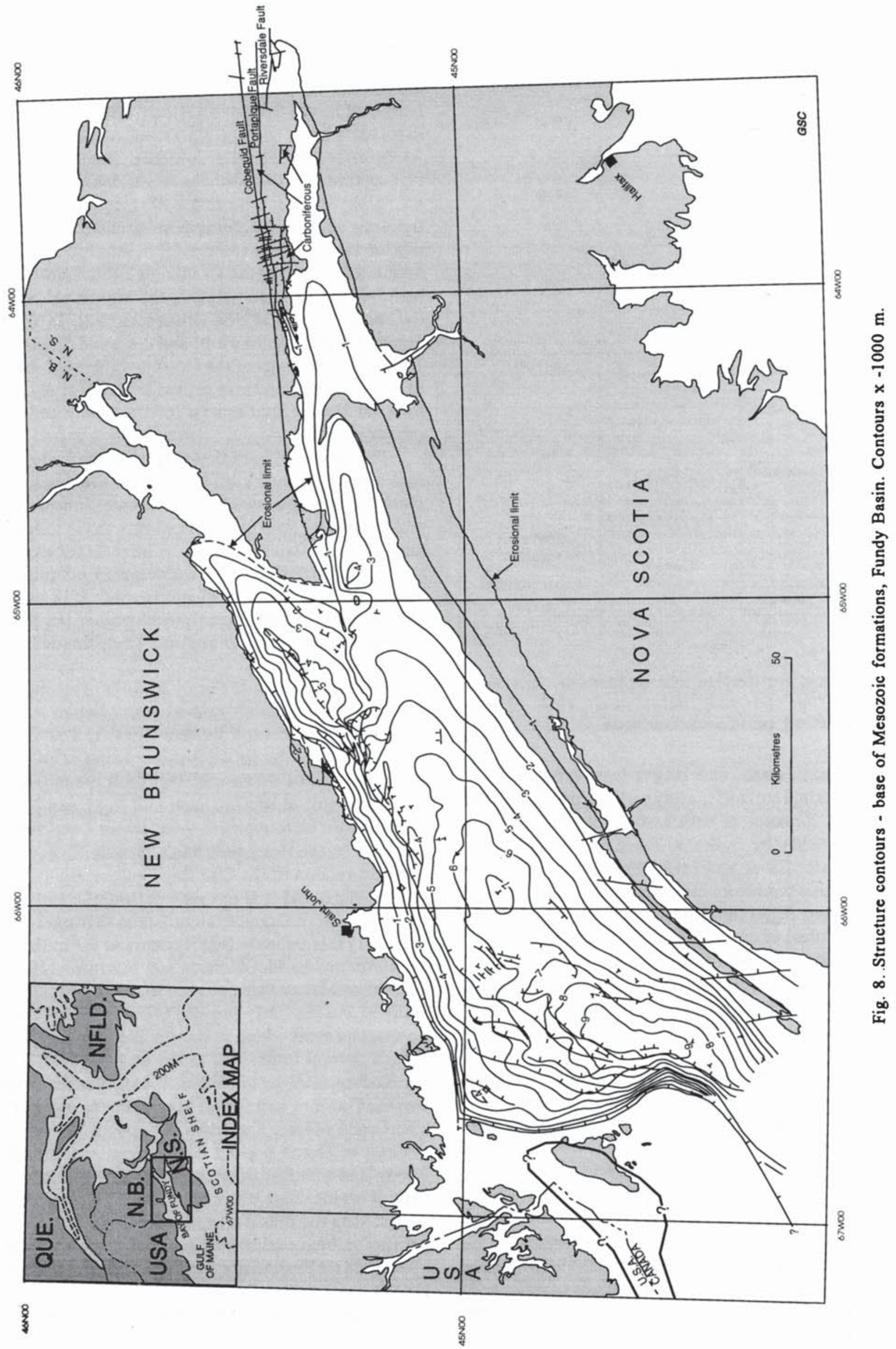




\section{CHINAMPAS}
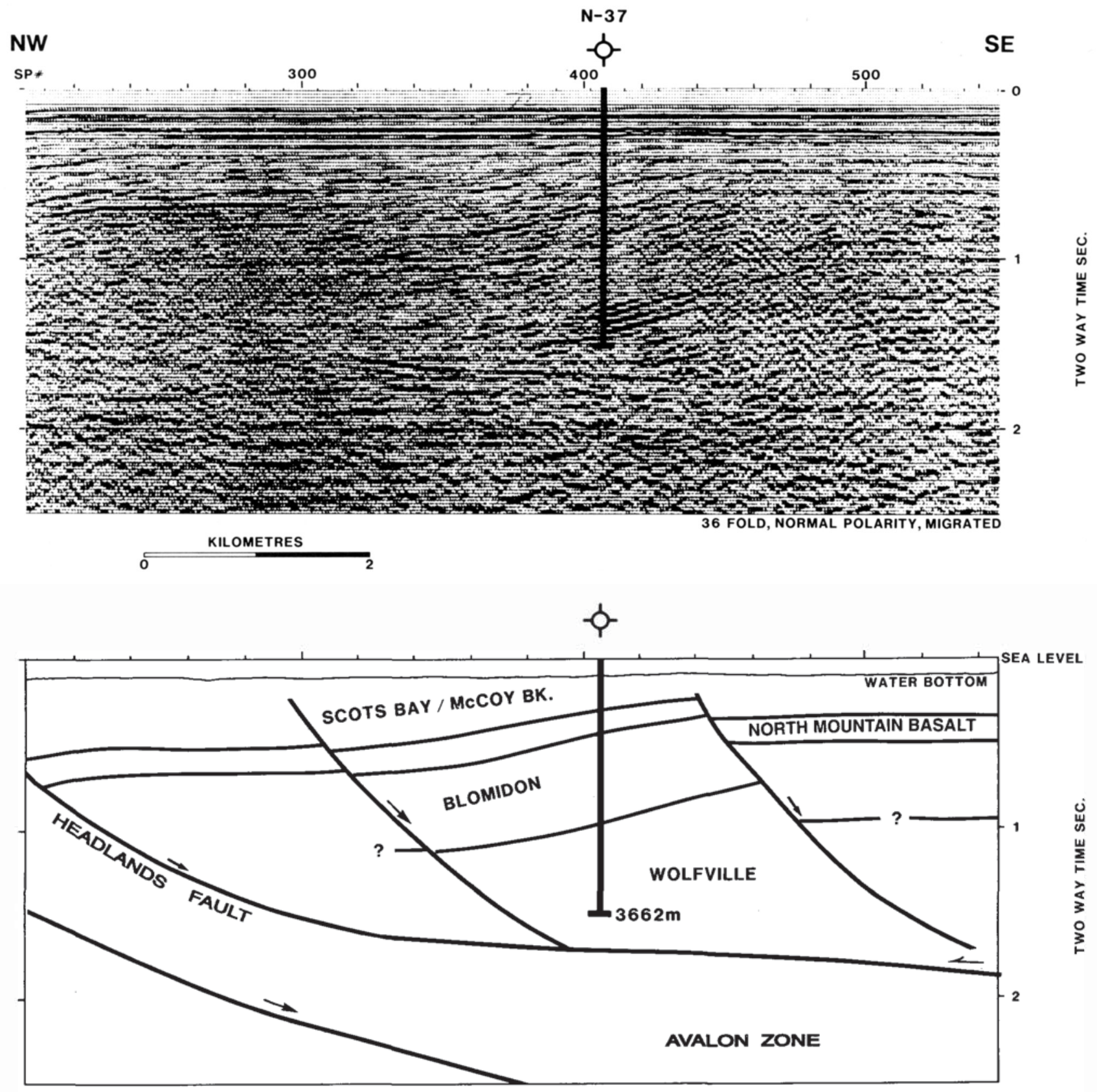

Fig. 9. Seismic section and line drawing of BF-72B through Mobil Gulf Chinampas N-37. Location in Figure 3.

land Nova Scotia and the Scotian Basin to the continental slope is shown in Figures 6 and 13. Of interest structurally are the opposing faults bounding Fundy Basin and the Naskapi and Mohican grabens on the Scotian Shelf which project to sole in a lower crustal position beneath Nova Scotia. Although the fault sets are related to previous zones of weakness, we interpret the present relationship as possibly resulting from deep regional uplift or doming, the axis of which was roughly coincident to Nova Scotia. Farther to the southeast, across the basement hinge zone (Jansa and Wade, 1975a; Wade and MacLean, 1990), the Triassic rift-bounding faults again dip to the south.

The amount of movement required to form Fundy Basin can be estimated from the distance that the pre-Meso- zoic basement is offset across the two bounding fault systems. Approximately 10 to $15 \mathrm{~km}$ of horizontal displacement is measured on the Grand Manan Fault. This is an indication of the amount of sinstral movement on the Headlands Fault System. Similarly, 10 to $12 \mathrm{~km}$ of horizontal displacement occurs on the Headlands Fault System resulting from dextral movement on the Grand Manan Fault during development of the basin (Fig. 14). Fundy Basin thus was dominated by extension. A total vertical movement of approximately $12 \mathrm{~km}$ is indicated by our interpretation of maximum sediment fill. As described below, the nature and distribution of the sedimentary facies in the basin is strongly influenced by the rate of extension.

Contours on the interpreted base of the Mesozoic se- 

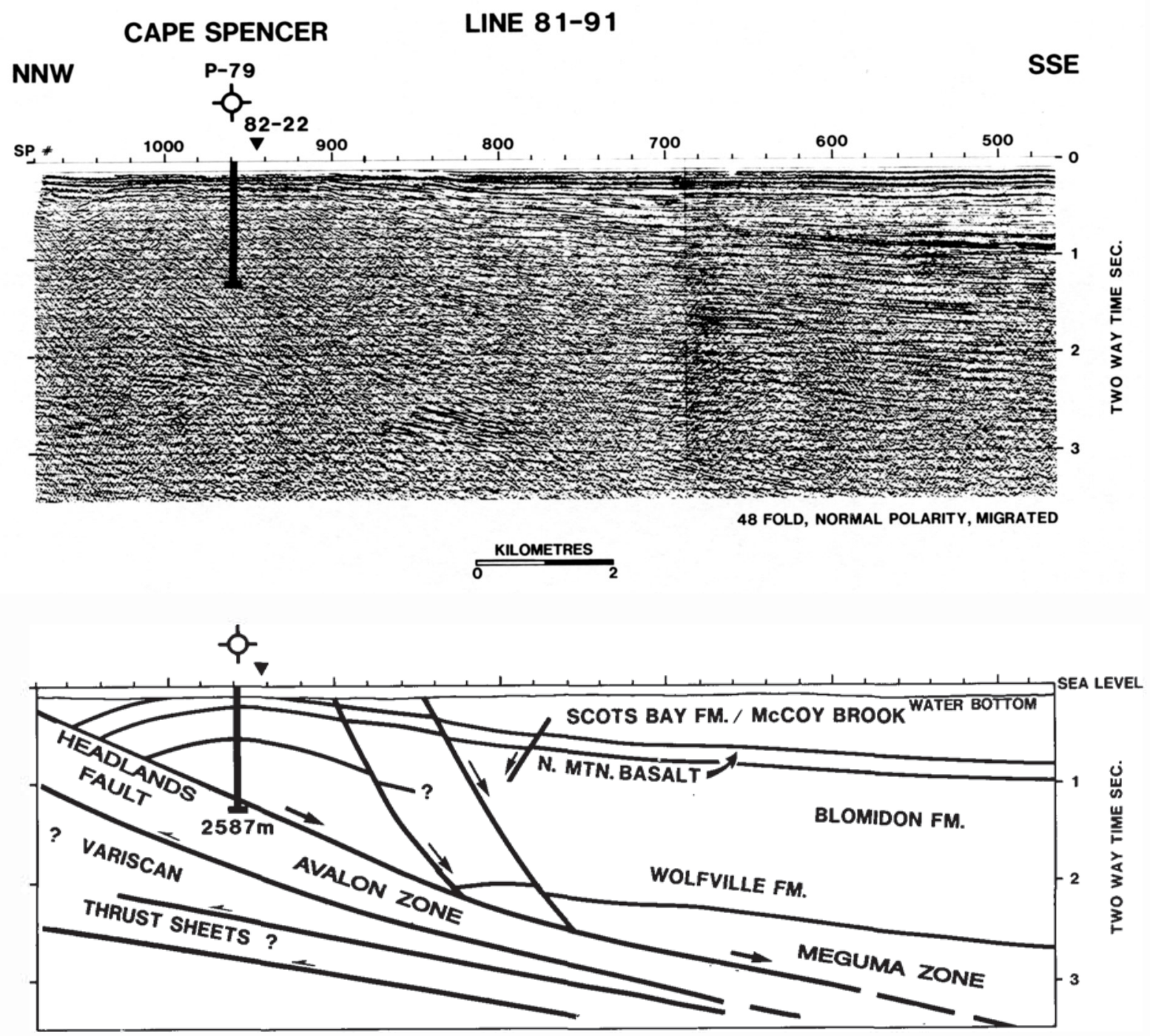

Fig. 10. Seismic section and line drawing of 81-91 through Irving Chevron et al. Cape Spencer No. 1. Location in Figure 3.

quences outline a southwesterly plunging basin which extends from Minas Basin to just south of Grand Manan Island (Fig. 8). The maximum present depth to basement, adjacent to the Grand Manan Fault, is interpreted to be just over 9.5 $\mathrm{km}$. At the junction of the Headlands and Cobequid faults the basin axis bifurcates. One arm extends across the fault zone into Chignecto Bay to form the Chignecto Subbasin which has a current maximum depth of about $5 \mathrm{~km}$. The other arm, which parallels the Cobequid Fault, forms Minas Subbasin.

Our interpretation of depth to basement for Fundy Basin, as shown in Figures 1, 5 and 8, is substantially different from depths published by Schlische and Olsen (1990) and Withjack et al. (1995). The former used estimates based on thickness of marginal outcrop section and the latter assumed an average subsurface velocity of $3.5 \mathrm{~km} / \mathrm{s}$ for converting seismic times to depth. In our study, we have used a variety of data and methods to develop basement depth. The seismic records from the Fundy Subbasin lack a distinctive reflection from the pre-Mesozoic surface due in part to similarities in velocity between the adjacent facies. Meguma velocities have been measured from 5.3 to $6.5 \mathrm{~km} / \mathrm{s}$ (Coflin,
1996; Keen et al., 1990) and the lower part of overlying Wolfville Formation in the Chinampas well has a measured velocity of $5.5 \mathrm{~km} / \mathrm{s}$. Similarily, measured velocity data from the Scots Bay Formation is $3.5 \mathrm{~km} / \mathrm{s}$ and from the North Mountain Basalt is $4.7 \mathrm{~km} / \mathrm{s}$ (Mobil Oil Canada, Ltd., 1975). The velocity data were combined to develop a series of velocity versus depth curves for the various stratigraphic situations which occur throughout the basin. A base of Mesozoic pick on the seismic data was developed first for those lines approaching the North Mountain where basement could be projected into the bay using known formation thicknesses and dips. In several cases this projected surface was found to coincide with a zone of character change on the seismic records between fair to weakly coherent energy (assumed Wolfville Formation) and generally incoherent (assumed Meguma Group). This surface was tied throughout the seismic data set, depth converted, and mapped as approximate base Mesozoic (Fig. 8). Measured variations in formation dips and thicknesses from the Annapolis Valley and North Mountain, when projected to the basin axis, agree well with the seismically derived depths.

The Chignecto Subbasin lies northeast of the junction 


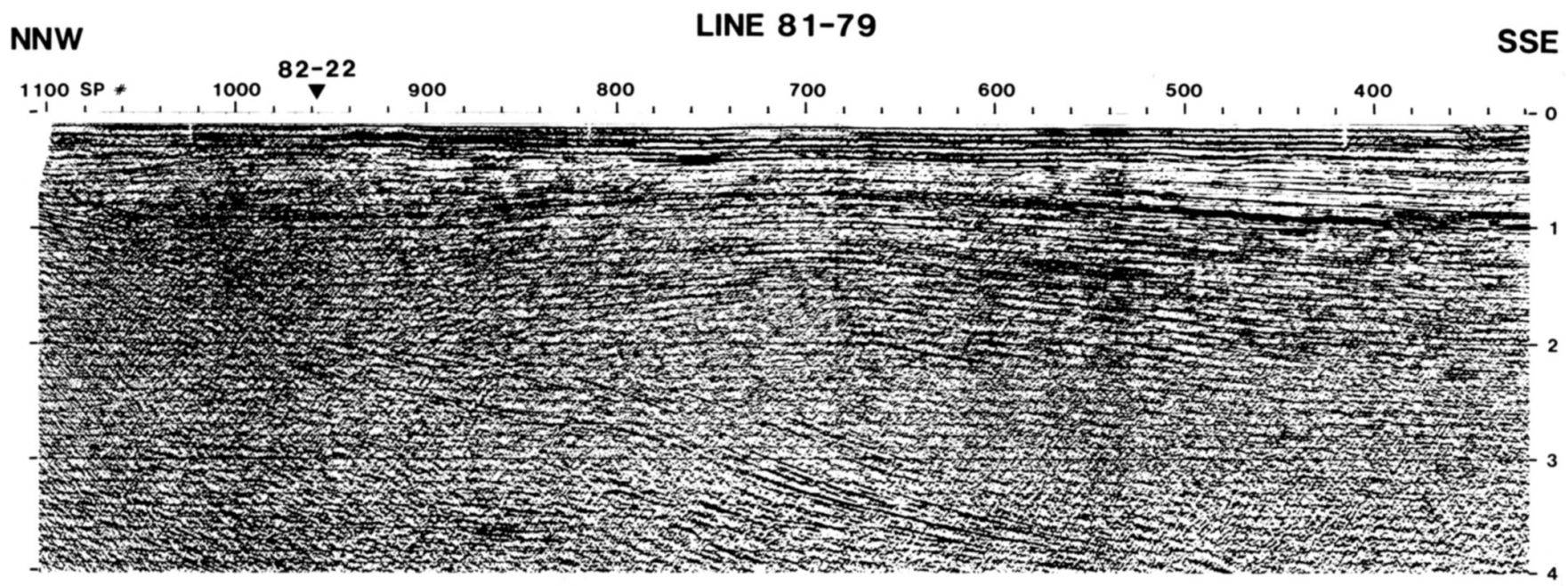

48 FOLD, NORMAL POLARITY, MIGRATED

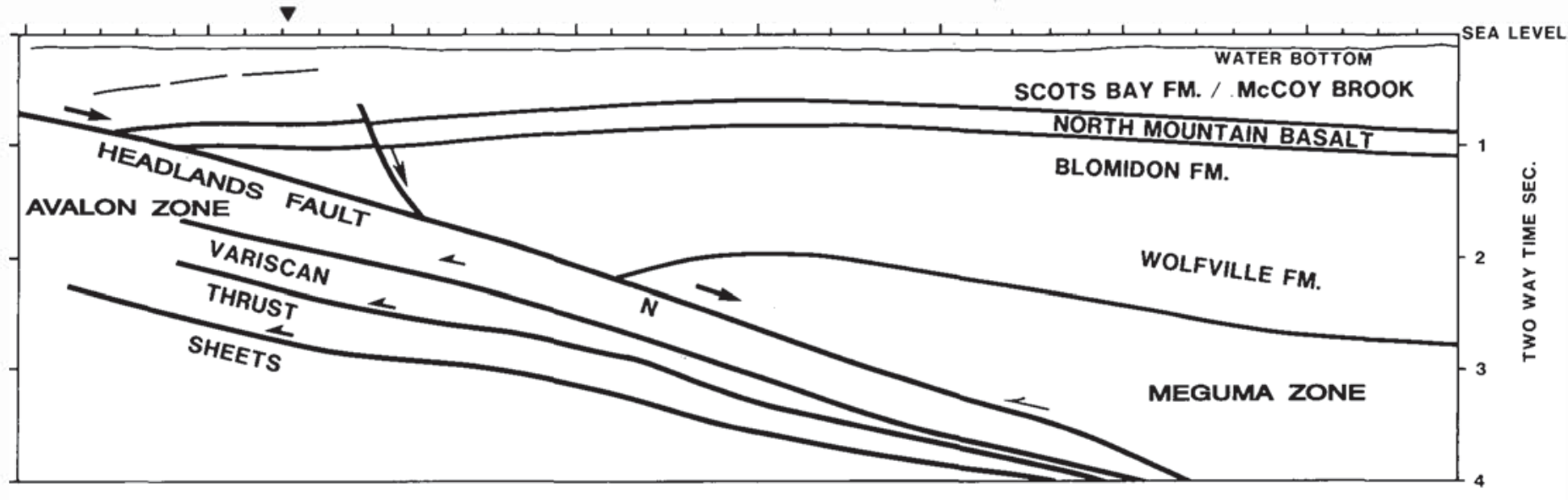

Fig. 11. Seismic section and line drawing of 81-79. Location in Figure 3.

of the Headlands and Cobequid fault systems. That the normal border fault was influenced by the merging transcurrent fault is indicated by the northward deflection of the former and the resultant preservation of possible Middle Triassic facies in southern New Brunswick. This structural corner may have resulted in a focus of Triassic drainage and hence the thick alluvial fan and fluvial sequences seen in the St. Martins area and their interpreted extension into the adjacent Chignecto Subbasin. Pre-Mesozoic basement in this subbasin is well defined seismically as an angular unconformity on late Paleozoic strata (Fig. 12).

The southern limit of the Chignecto Subbasin is formed by the westward extension of the Cobequid Fault which is seen on seismic profiles as a zone of flower structures (Figs. 4,12 ). It must be remembered that these features are postdepositional. It is likely that the fault is syndepositional although the full extent of its affect on the early development of the subbasin is not known. The industry seismic data in this area are limited to the Bay of Fundy and the southern part of Chignecto Bay. Unfortunately, in the latter area, the lines do not extend far enough to the northeast to properly define the extent and thickness of the Mesozoic section. However, seismic lines which cross the Cobequid Fault trend show approximately basement-parallel bedding upturned and eroded with no indication of onlap onto a predepositional feature.

The other arm of the Fundy rift, which forms the Minas Subbasin, lies south of the Cobequid Fault and east of a transverse basement arch or ridge (at about $65^{\circ} \mathrm{W}$ ) beneath Isle Haute (Figs. 3, 8, 15). The axis of Minas Subbasin extends from east of Isle Haute, beneath Minas Basin and Cobequid Bay. This subbasin exhibits a significantly different style of tectonism from the other two subbasins. The border faults dip steeply to the south with strike-slip being the dominant process (Donohoe and Wallace, 1982; Schlische, 1990). In such a setting, with the major movement nearly parallel to the strike of the basin bounding faults, the horizontal extensional component is greatly reduced relative to that observed in the Fundy and Chignecto depocentres. Also, the present stratigraphic section is thinner than in the dip-slip dominated subbasins (Fig. 8). Moreover, the strata are more likely to be subjected to continuous syndepositional tectonics with resultant complexity of sedimentary facies. There- 

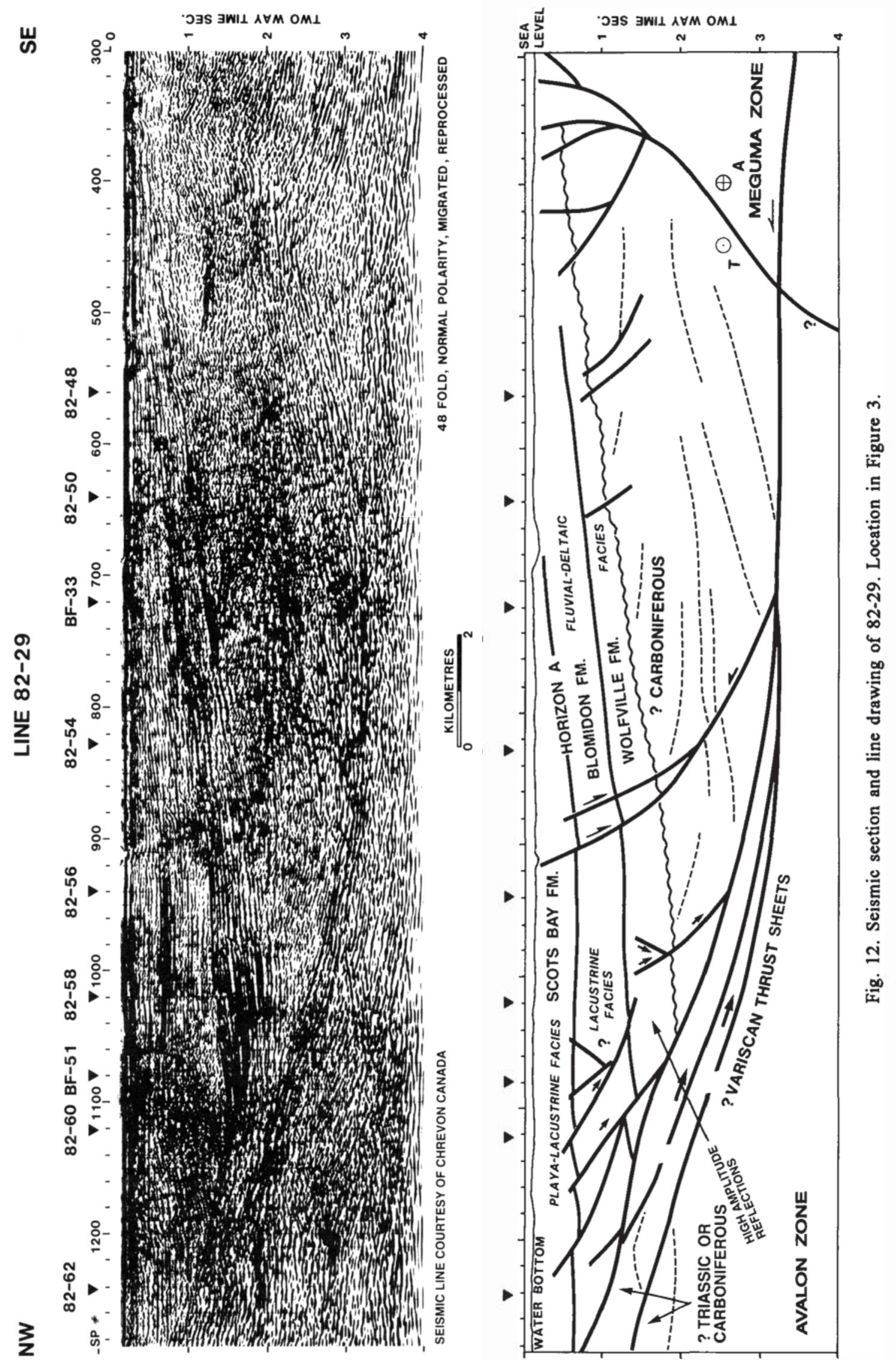


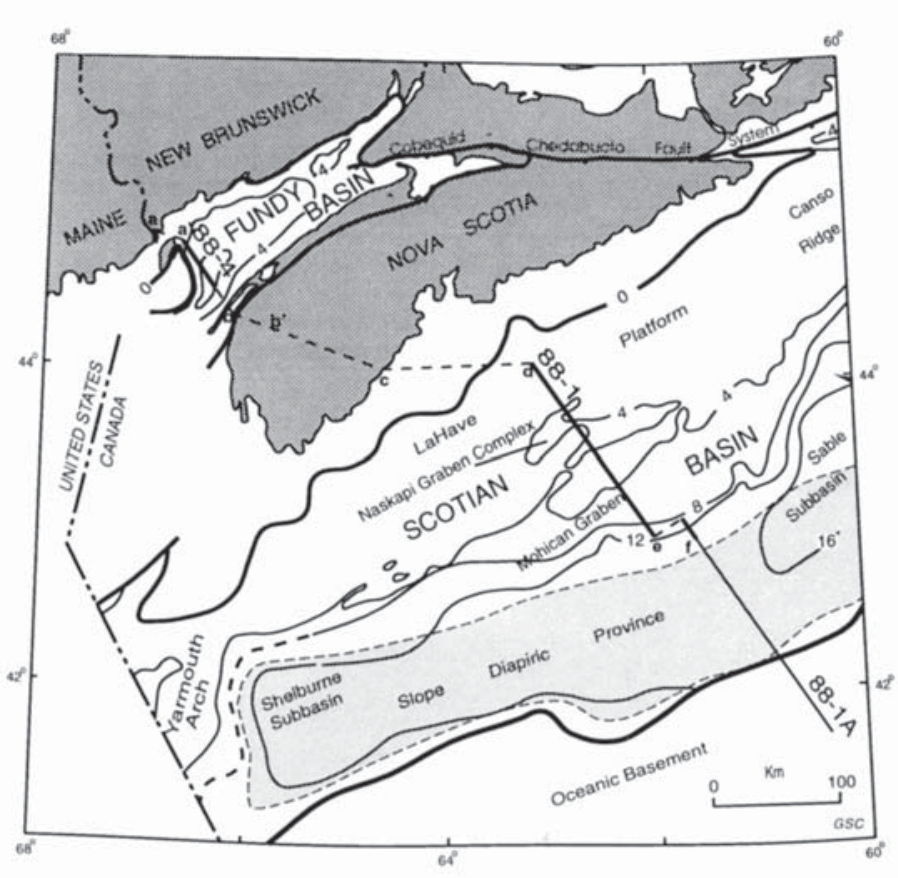

Fig. 13. Index map of major tectonic elements on the western Scotian Shelf and showing the location of regional cross section a-f.

fore, although the depth to basement is unknown due to a lack of seismic profiles, the remaining thickness of strata in Minas Subbasin is estimated from outcrop dip and thickness data to be from 2 to $3 \mathrm{~km}$ (Fig. 8).

Following the confirmation of Blomidon Formation equivalent strata beneath the North Mountain Basalt on Grand Manan Island (Wade and Jansa, 1994), a fourth subbasin was outlined including the western part of the island and a portion of the adjacent Grand Manan Channel (Fig. 1). The bounding fault for this subbasin may be the major feature which trends roughly north-south across the island and dips to the west. However, a southwestward extension of the Headlands Fault System probably occurs beneath Grand Manan Channel. Regional gravity anomaly data show a significant negative anomaly along the Headlands Fault which continues west of Grand Manan (Shih et al., 1993). The total thickness of strata in the Grand Manan Subbasin is unknown.

There has been some speculation about the existence of a south-bounding fault for the Bay of Fundy graben (Keppie, 1977; Perkins, 1981). The offshore seismic data clearly indicate that such a feature does not exist beneath the Bay of Fundy and, from the southward projection of stratigraphic units, that Fundy Basin, like many of the other basins in the Triassic-Jurassic rift system, is indeed a half graben. There is both outcrop and seismic evidence of small, down-to-thenorth faults which offset basement, but these also offset the Triassic/Jurassic formations and were not a primary mechanism of graben formation. Neither is a south-bounding fault required. The seismically defined stratigraphic succession filling Fundy Basin comprises a series of gradually northwesterly thickening wedges. This is also consistent with the finer grained fluvial facies seen in outcrop in southwestern Nova Scotia.

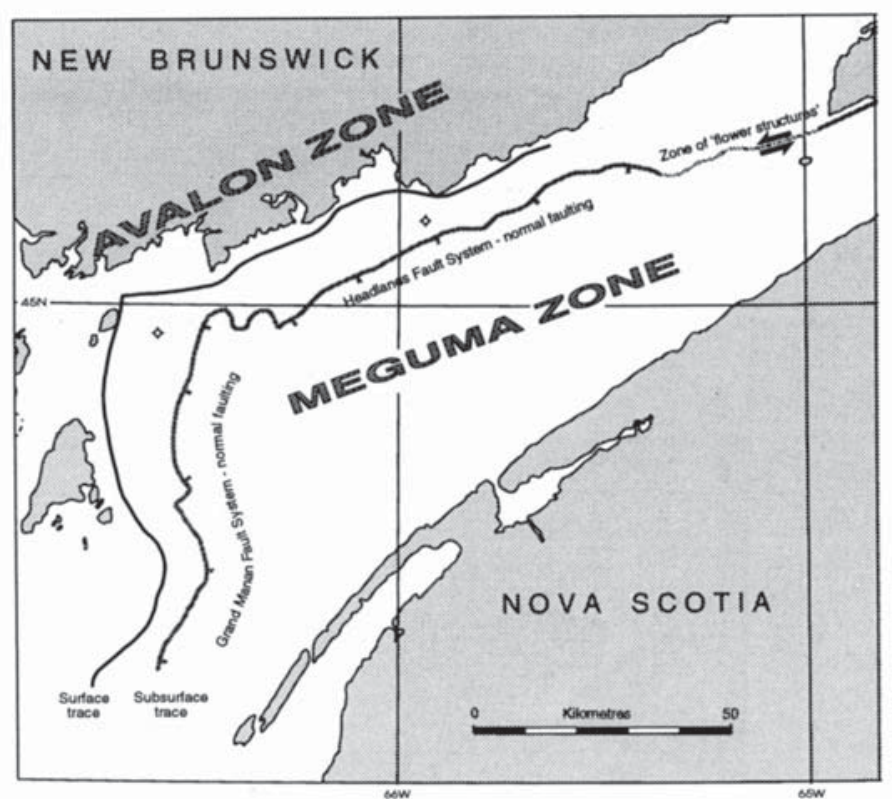

Fig. 14. Interpreted Avalon/Meguma zone boundary at the Grand Manan and Headlands Fault Systems. Black line is the surface trace, shaded line is the interpreted trace in the hanging wall block. The distance between the two represents the approximate amount of movement involved during development of the basin. The vertical component, determined from maximum sediment fill in Fundy Basin, is about $12 \mathrm{~km}$.

Within the main part of Fundy Subbasin, there is a postHettangian structural sag. The southeast side of this feature is represented by a flexure (in places possibly a fault) in the North Mountain Basalt with a relief of approximately 300 $\mathrm{m}$ (Figs. 15, 16). The northwestern side is a listric normal fault that also offsets basement (see SP $\mathbf{4 0 0}$ in Figure 5 and SP 1300 in Figure 16). The cause of this structural feature is not clear, although it is probably the result of late extensional adjustments. Alternatively, this sag might be attributed to dissolution of evaporites from playa facies in the Blomidon Formation. However, no major disruptions related to dissolution and/or karsting are observed in the seismic reflections from beneath the basalt that could account for the magnitude of the sag. Indeed, there is no seismic evidence for the prior or present existence of any significant quantities of evaporites in the basins, although minor but laterally extensive interstratal deformation and karsting has been reported onshore in the Minas Subbasin (Ackermann and Schlische, 1993).

\section{Basin filling MOdels}

Fundy Basin is one of many early Mesozoic rift basins extending, both onshore and offshore, from Florida to The Grand Banks of Newfoundland. These basins were filled with continental sedimentary rocks and basalts which comprise the Newark Supergroup and which were deposited over a 45 million year period from the early Late Triassic to the Early Jurassic (Olsen, 1988a; Harland et al., 1990). However, Fundy Basin may be unique in that its preserved strata 


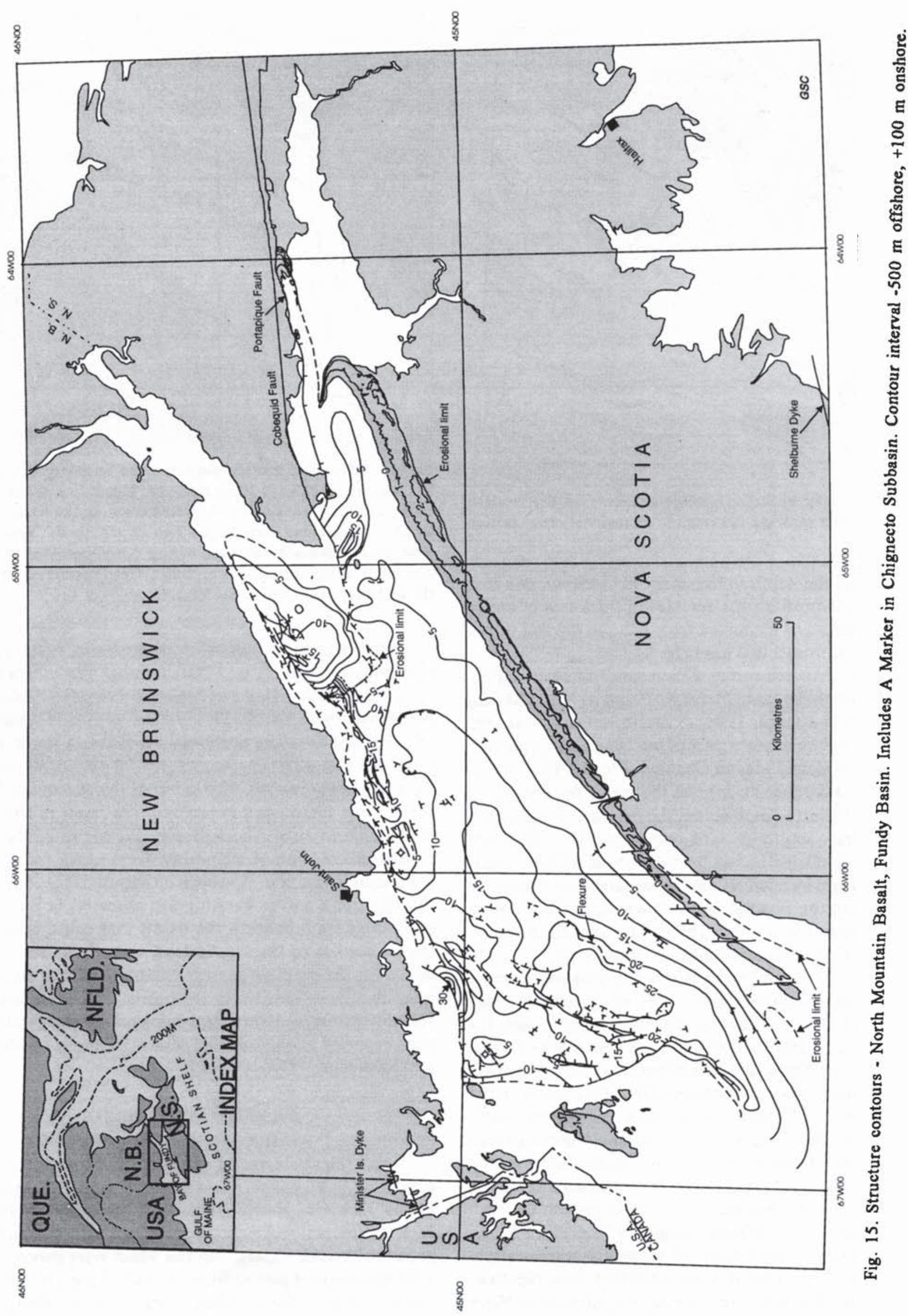



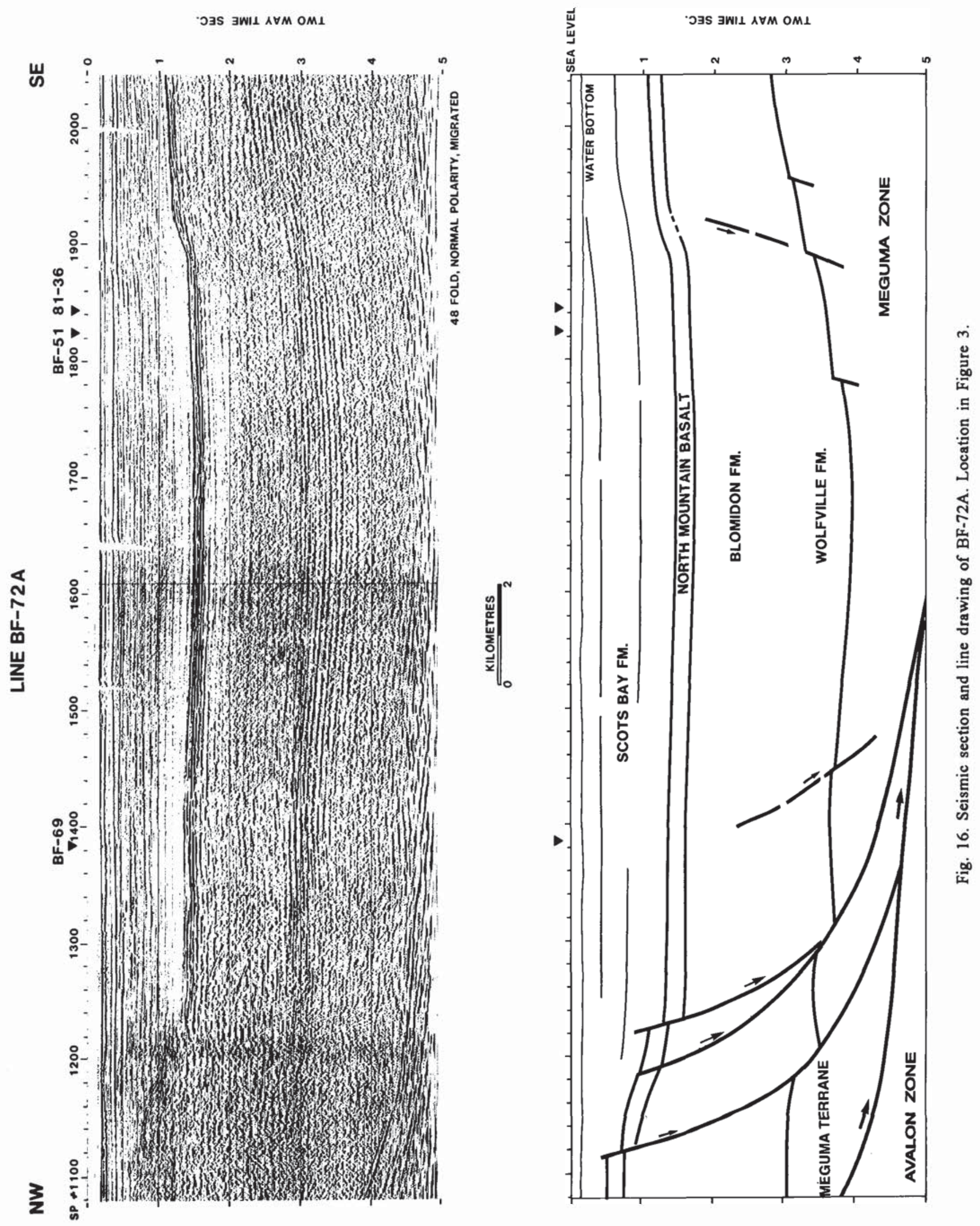
appear to span a significantly greater age range, stretching from the Anisian (Olsen, 1988a) to, depending on depositional rates, at least the Aalenian (Fig. 7), i.e., about 65 Ma.

Sedimentary sequences of the Newark Supergroup are commonly wedge-shaped, thickening and dipping toward the border fault. The strata generally display a stratigraphy consisting of a basal fluvial section indicating a hydrologically open basin, overlain by a deep water lacustrine interval then followed by a shallow lacustrine/playa to fluvial section indicating a hydrologically closed basin (Olsen, 1990). Schlische and Olsen (1990) developed a quantitative model for the stratigraphic evolution of rift basins in which they assumed: (1) a constant volume input of sediments and water per unit time, (2) a uniform subsidence rate, and (3) a fixed outlet level. The model enables separation of events due to filling under the assumed constant conditions from those due to changes in tectonics, climate or sediment and water budgets.

Smoot (1991) refined this model slightly to address observed basin facies patterns and consider the effects on facies distribution from regional changes in subsidence, drainage patterns, and climate. His model begins with a slow subsidence rate or high sediment supply that results in the deposition of a basal fluvial facies. Continuous subsidence permits the basin to fill slowly with sediments that spread over an increasingly larger area, but in progressively thinner sheets. Eventually, infilling lowers the basin floor relief and decreases the gradients of inflowing streams. With their downcutting power retarded, the watercourses deposit finer grained sediments which, in turn, further reduces their erosional ability. Shallow lakes are formed and eventually the basin becomes closed. With the sedimentation rate continuously decreasing over time, the lacustrine facies expands in area and depth. The eventual establishment of an equilibrium between inflow, seepage and evaporation causes the lake to cease growing, and its area and depth to wane. Mixed smallscale fluvial systems and shallow lacustrine/playa facies eventually develop on the basin floor.

Playa/lacustrine facies constitute the bulk of the strata in the Newark Supergroup. Olsen (1990) proposed that within the basins, three types of lacustrine facies complexes could be recognized. Of these the "Richmond-type" reflects the wettest conditions in which water inflow (rainfall and runoff) exceeds outflow (evaporation, seepage and drainage). "Newark-type" complexes are the most common and contain facies indicating a general balance between inflow and outflow, while "Fundy-type" facies are considered the driest and contain strata indicative of conditions where water inflow was less than outflow.

Many other workers in the Newark Supergroup have commented on the apparent northeasterly trend toward increasing aridity as indicated by sedimentary facies (Manspeizer, 1982; Hubert and Mertz, 1984; Smoot and Olsen, 1988; and others). Smoot and Olsen (1988) and Smoot (1993) interpret that a Fundy-type lacustrine facies complex is present in similar aged strata of the Argana basin of Morocco at the same paleolatitude as Fundy Basin during Triassic-Jurassic time. The causes of this trend have yet to be quantified, but are believed to be due to the combined effects of the meridinal distribution of the Triassic-Jurassic rift basins $\left(0^{\circ}-15^{\circ} \mathrm{N}\right)$, climatic circulation patterns and elevation.

As further discussed below, the Wolfville and Blomidon formations in Fundy Basin seem to reflect predominantly Fundy-type lacustrine complexes whereas the Scots Bay Formation is here interpreted as a Newark-type lacustrine succession.

\section{REgIONAL STRATIGRAPHY}

Four distinctive formations comprise the Middle Triassic to Lower Jurassic stratigraphic succession in Nova Scotia (Fig. 7). In ascending order these formations are the Wolfville, Blomidon, North Mountain Basalt and Scots Bay (Powers, 1916; Klein, 1954, 1962; Williams et al., 1985). On the northern margin of Minas Subbasin, the lacustrine Scots Bay Formation is replaced by the informally named McCoy Brook formation (Donohoe and Wallace, 1978; Williams et al., 1985) which includes a coeval fluvial to lacustrine clastic-rich facies and eolian units. In southern New Brunswick, four formations representing proximal alluvial fan facies, equivalent to the Wolfville Formation, have been identified (Powers, 1916; Magnusson, 1955; Nadon, 1981; Nadon and Middleton, 1984).

The present low-lying upland physiography of the Meguma surface in Nova Scotia and an updip (southeasterly) projection of sedimentary sequences from the Bay of Fundy might suggest that much of mainland Nova Scotia had at least some Triassic cover. However, Fundy Basin formed in an elevated continental rift valley due to continuous subsidence along northern and western border fault systems. The basin was flanked by mountains of moderate relief and, after restoring $2+\mathrm{km}$ of (post-Mid Jurassic) basement erosion, the actual maximum southerly extent of the Mesozoic formations may not have been much beyond the present crest of South Mountain. As described below, this is consistent with the nature of the clastic facies found along this margin.

\section{Wolfville Formation}

Exposures of the Wolfville Formation occur along both sides of Minas Basin and Cobequid Bay and sporadically in the Annapolis Valley (Figs. 3, 17) (Keppie, 1979; Donohoe and Wallace, 1982). The Wolfville Formation unconformably overlies Carboniferous and older sedimentary, metasedimentary or igneous rocks. Although rarely exposed, the unconformity can be seen clearly at Rainy Cove and Clemment Cove on the southern shore of Minas Basin, near Walton (Fig. 18) and, poorly, in several stream valleys along the south side of the Annapolis Valley. The lower part of the formation is exposed along the south side of Minas Basin and about 365 $\mathrm{m}$ of the upper part of the formation is included in the type section, along the west shore of Minas Basin from Paddy Island to Kingsport (Klein, 1962). Toward the north side of Fundy Basin, the Irving Cape Spencer No. 1 and Mobil Gulf Chinampas N-37 wells (Fig. 3) encountered $1308 \mathrm{~m}$ and 


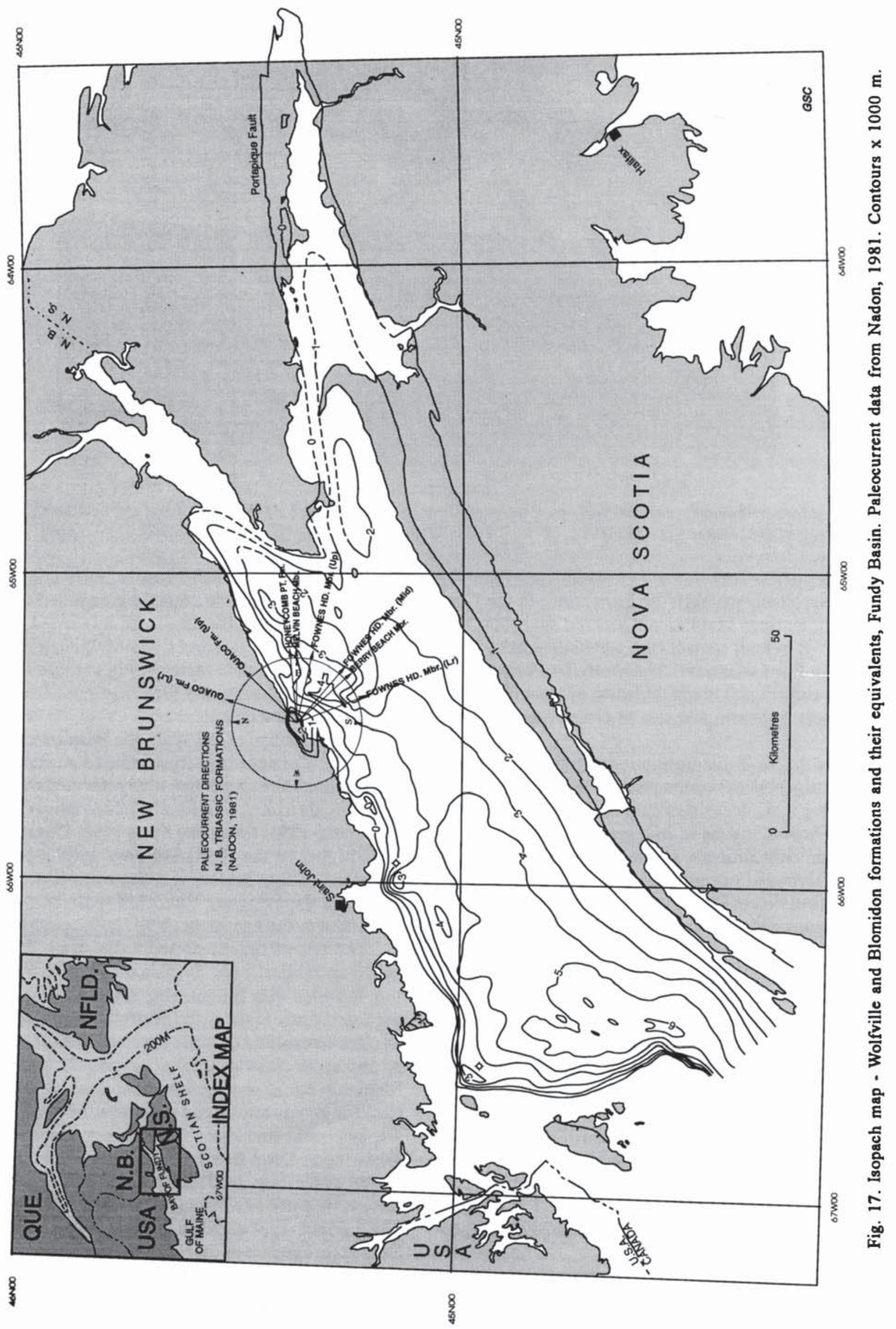




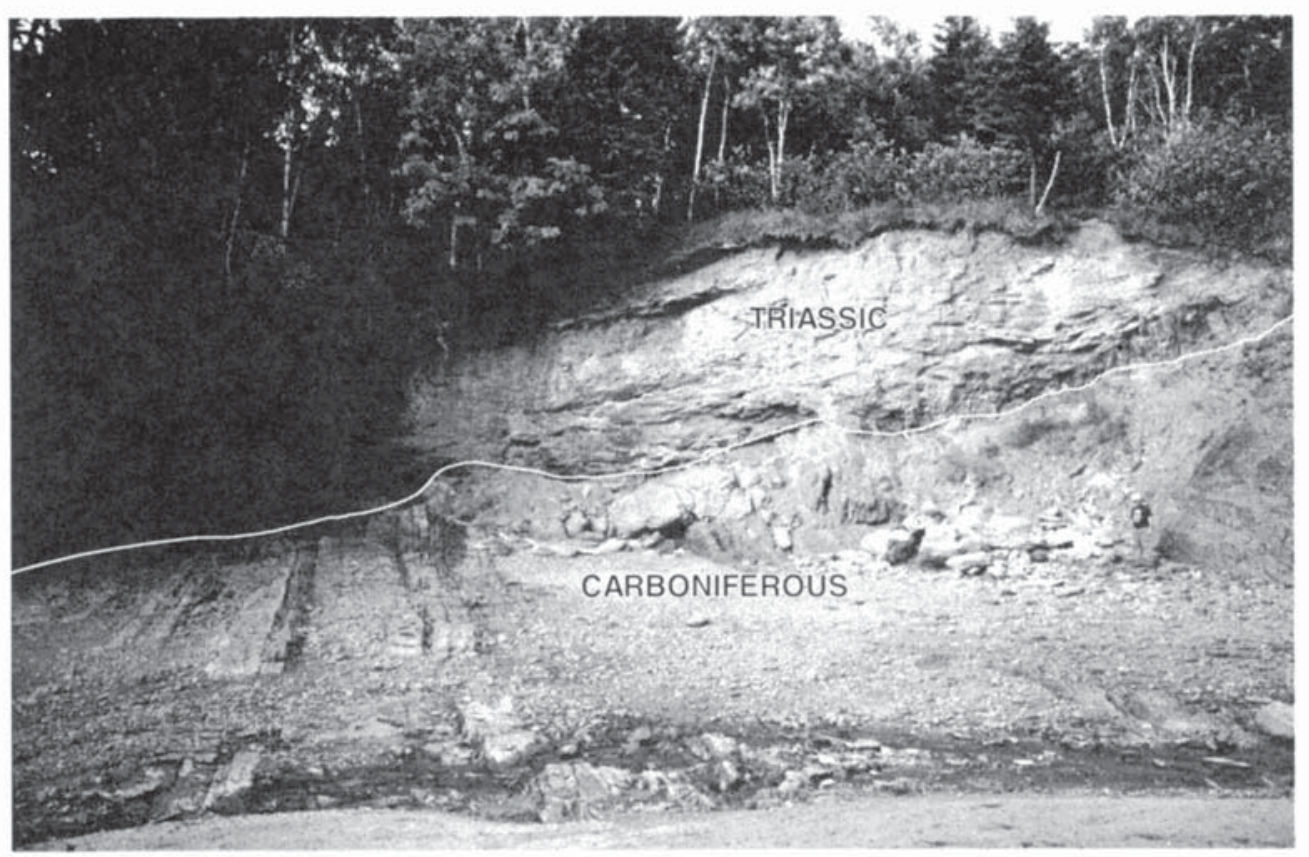

Fig. 18. Unconformity between near vertical, dark grey, argillacous siltstones and sandstones of the Carboniferous Horton Group and gently dipping, red, coarse grained clastics of the Triassic Wolfville Formation at Clemment Cove, Nova Scotia. Note figure on right for scale.

1718 $+\mathrm{m}$ respectively of Wolfville Formation. In the Cape Spencer well, cuttings samples and seismic data show that the formation is in fault contact with metasedimentary rocks of the Avalon Zone basement. The Wolfville Formation is estimated to attain a maximum thickness of more than 3000 $\mathrm{m}$ in the Fundy Subbasin just east of Grand Manan Island (Fig. 17).

Strata of the Wolfville Formation represent the initial phase of continental rift sedimentation within Fundy Basin. In outcrops, the formation consists of a variety of orange, red to brown, coarse to fine grained sandstone, pebbly sandstone, conglomerate and minor shale. These sediments are interpreted to represent braided river, sand flat, alluvial fan and eolian depositional environments, deposited under semi-arid conditions (Klein, 1962, Hubert and Forlenza, 1988). Based on paleocurrent data from fluvial strata of the Wolfville Formation, Hubert and Forlenza (1988) developed a paleogeographic interpretation for the Cobequid Bay/Minas Basin area indicating the presence of a northsouth trending height of land at about $64^{\circ} 15^{\prime} \mathrm{W}$ longitude. This interpreted divide deflected rivers eastward to flow probably into the Orpheus Graben, located south of Cape Breton, and westward toward the major Fundy Subbasin depocentre near Grand Manan. The lack of deep seismic data in Minas Subbasin precludes confirmation of this divide. Hubert and Mertz (1980, 1984) described eolian dune fields within the Wolfville Formation on the north side of Minas Subbasin (Fig. 19) and interpreted a seasonally hot and semiarid climate with prevailing northeasterly winds.

Identification of the top of the Wolfville Formation in the cuttings samples from the offshore wells is based on the upward transition from predominantly coarse to predominantly fine grained clastic sequences. In these wells, Wolfville
Formation lithologies are mainly pink to red coarse grained to conglomeratic sandstones with minor red to red-brown siltstone and shale interbeds. The Chignecto Subbasin contains a unique seismic facies of high amplitude reflections from beds ascribed to the Wolfville Formation. These are further discussed below.

The age range of the Wolfville Formation is somewhat uncertain. The upper age limit is based on vertebrate faunal remains found in exposures along the south side of Minas Subbasin; these are believed to be mid to latest Carnian (Baird and Olsen, 1983; Olsen and Sues, 1986; Olsen et al., 1989). Beds higher in the formation have been given a Carnian age based on fragmentary vertebrate remains. Palynomorph data from the overlying Blomidon sediments add a further constraint to the age range.

The age of the oldest Wolfville strata is less certain. Based on Schlische and Olsen's (1990) model for basin filling, together with the ramping margin location of most of the fossil finds to date, the Wolfville Formation should be no older than earliest Carnian. However, within Minas Subbasin, on the south flank of a horst associated with the Garrish Mountain Fault, is a section dominated by $<1 \mathrm{~m}$ thick cyclic, fining upward fluvial sequences of minor conglomerate, sandstone and shale. This section crops out along the shoreline at Carrs Brook near Lower Economy (Fig. 3). A variety of mollusc, reptile and amphibian remains from this section are dated as Anisian (Mid Triassic) (Baird and Olsen, 1983; Olsen, 1988a; Olsen et al., 1989) suggesting an earlier age for the base of the Wolfville Formation. These strata, unlike most exposures of the Wolfville Formation, are moderately disturbed by the adjacent faulting.

The Carrs Brook section may represent an earlier phase of Triassic sedimentation not observed elsewhere in Fundy 


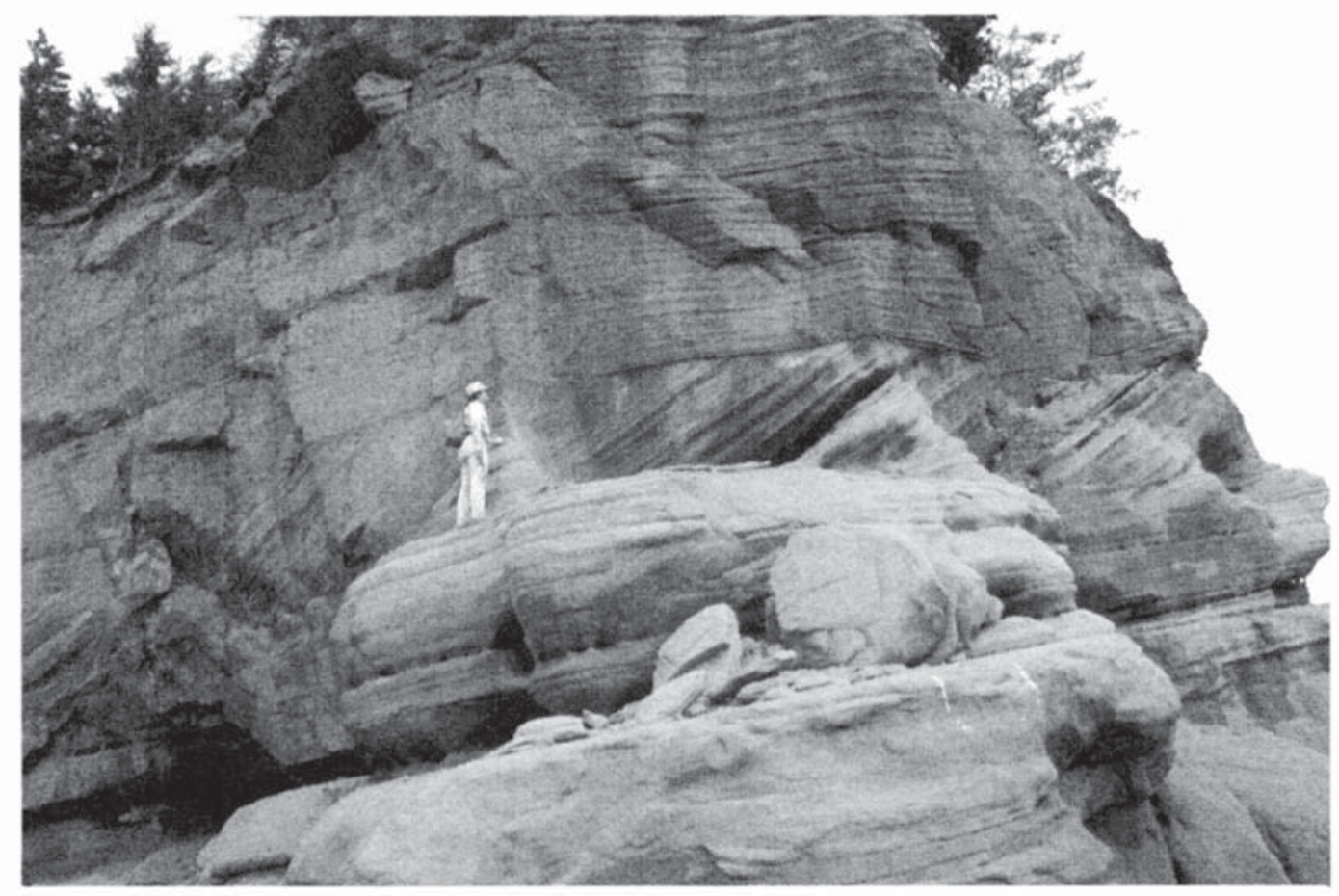

Fig. 19. Eolian sandstones at the top of the Wolfville Formation, Red Head, Five Islands area, Nova Scotia. The paleowind direction was from northeast to southwest (right to left).

Basin except possibly at Point Lepreau (see below). Due to the amount of uplift and erosion, the relationship with adjacent exposures of the Wolfville Formation is unknown. J. Smoot (personal communication, 1994) indicated an unconformable relationship in similar facies of the Argana Basin. There, Carrs Brook-like fluvial and eolian sediments are steeply tilted and are unconformably overlain by younger Carnian fluvial strata. Regardless, the strata at Carrs Brook clearly fall within the present definition of the Wolfville Formation and provide evidence of sedimentation ranging back into the Mid Triassic and thus perhaps relating to the earliest phases of the Mesozoic rifting in North America.

\section{Wolfville Formation equivalents}

Along the southern coast of New Brunswick, the faulted northwestern margin of the basin, there are a series of isolated Carnian-Norian? clastic facies in outcrops from Waterside in the northeast to Split Rock in the southwest, that perhaps all equate to the Wolfville Formation (Fig. 7). In addition, purplish red to red-brown sandstone and conglomerate facies in the Lepreau area have been tentatively assigned to the Triassic. In probable ascending order, the New Brunswick Triassic formations are: Lepreau, Honeycomb Point, Quaco, and Echo Cove (Powers, 1916; Wright and Clements, 1943; Magnusson, 1955; Klein, 1962; Sarjeant and Stringer, 1978; Nadon, 1981). Nadon (1981) further subdivided the Lepreau Formation into the Fishing Point, Duck Cove and Maces Bay members; the Honeycomb Point Formation into the Browns Beach and McCumber Point members; and the Echo Cove Formation into the Stony Brook, Berry Beach, Fownes Head and Melvin Beach members. A summary description of the
New Brunswick formations and their interpreted relationships to the Wolfville Formation follows.

\section{Lepreau Formation}

This formation consists of about $3 \mathrm{~km}$ of coarse arkosic, red to dark red, alluvial fan/playa and braided fluvial sandstones and conglomerates sourced from the north and northeast (Sarjeant and Stringer, 1978; Nadon, 1981). Although tentatively assigned to the Triassic, a lack of datable fossils leaves the age of this formation in doubt. However, detailed ichnological studies suggest a correlation with the Late Triassic Honeycomb Point Formation further to the northeast (MacNaughton, 1990). The strongly folded Lepreau Formation is in fault contact with Pennsylvanian, Mississippian and Precambrian rocks.

\section{Honeycomb Point Formation}

The basal unit in the St. Martins area, $75 \mathrm{~km}$ northeast of Point Lepreau, is the Honeycomb Point Formation (Fig. 7), which consists of more than $1 \mathbf{~ k m}$ of north dipping, proximal alluvial fan deposits building out from the boundary fault and grading laterally into more distal sheet flood deposits (Nadon and Middleton, 1984). Breccias in the proximal facies contain abundant angular clasts of underlying Carboniferous and Precambrian formations, indicating limited transport. Cross-bedded sandstones, both fluvial and eolian, are common in the Honeycomb Point Formation, and their interbedded nature suggests a transition zone between active alluvial fan complexes and playa/lacustrine environments. Paleocurrent data indicate a northern and northwestern 
source for the fluvial sands whereas the eolian beds indicate prevailing east or northeast winds similar to those from other eolian sections in Fundy Basin (Nadon, 1981) (Fig. 17).

\section{Quaco Formation}

The distinctive, approximately $215 \mathrm{~m}$ thick, conglomeratic Quaco Formation unconformably overlies the Honeycomb Point Formation (Fig. 7). The cobble-size clasts are well rounded, predominantly grey quartzite and commonly 6 to $12 \mathrm{~cm}$ across. They are characterized by oval shaped dissolution pits, often with radiating fractures from pressure solution where they touch adjacent boulders; some also have crescentic percussion marks from fluvial transport (Klein, 1963a). Other cobble lithologies are granite and volcanic rocks. The matrix is generally coarse grained grey sandstone. Identical quartzite cobbles, but lacking the dissolution pits, were observed in conglomeratic units of unknown age underlying the Triassic to the north of Melvin Beach. It is reasonable to expect that such a mature roundstone has been reworked from another unit, although the mechanism involved is unknown.

Klein $(1962,1963 b)$ interpreted the Quaco Formation as a probable alluvial fan deposit sourced from the west or southwest. From paleocurrent and other sedimentological data, Nadon (1981) interpreted the Quaco Formation as a braided river deposit formed from a large, stable, axial river flowing toward the north or northeast along the northern side of the basin. The interpretation of river position fits well with the model for the evolution of the Mesozoic rift basins, where initial deposition was dominated by linear fluvial systems adjacent to the border fault. However, the concept of a northerly flow direction is more difficult to reconcile with the regional setting. It is generally agreed that the formations above and below the Quaco Formation represent alluvial fan and fluvial sediments sourced from the adjacent highlands to the north and west, and that these probably interfinger with sheet flood/playa facies to the south and southeast. Therefore, it is difficult to invoke an intervening period when the river flow was reversed and a major roundstone conglomerate was deposited in a generally conformable relationship with adjacent formations sourced from the northwest. Also, considering the broad regional setting, neither downstream (northward) facies or upstream (southerly) source area can be satisfactorily ascribed to such a system. However, it may be possible that, because of the few accessible exposures, Nadon's paleocurrent data was taken from a northerly flowing braided segment of a generally easterly flowing river.

Our field observations of the Quaco Formation and its relationship with adjacent units suggest probable rapid deposition of an already available cobble/boulder gravel supply brought about by unusual geological circumstances. These could include a sudden change in the elevation of the graben floor, resulting in the relocation or capture of rivers and rapid erosion and redeposition of an existing gravel or conglomerate unit. The Quaco Formation is considered too local, too unique and too uniform to have resulted from normal braided river processes acting over a long period of geologic time.

\section{Echo Cove Formation}

The Echo Cove Formation, which conformably and gradationally overlies the Quaco Formation (Fig. 7), is made up of medium to very coarse grained, red to red-grey sandstone and red to green shale, with numerous fanglomeratic to conglomeratic beds, particularly in the upper part of the formation. The formation is more than $1 \mathrm{~km}$ thick. Paleocurrent data from the members of the Echo Cove Formation indicate an orderly shift in source direction from northwest to west (Nadon, 1981; Nadon and Middleton, 1985) (Fig. 17).

Nadon and Middleton (1985), reporting on palynomorph assemblages from near the top of the Echo Cove Formation at Melvin Beach, indicated that the miospore assemblage is different from any in the eastern United States rift basins and, therefore, may signify a Ladinian (Mid Triassic) age. However, palynofloras recovered in the present study from the upper part of the Echo Cove Formation at Fownes Beach are dominated by several species from the Ovalipollis complex, relatively uncommon members of the Patinasporites complex and a variety of bisaccate pollen, including Alisporites spp. and Triadispora sp. Corollina is absent. This assemblage is clearly Carnian and probably Late Carnian (see also Traverse, 1983). Inasmuch as the Fownes Beach fossil occurrences are at least $2 \mathrm{~km}$ above the base of the Triassic sequence, they cannot be considered as indicative of its maximum age and allow speculation of earlier Mid Triassic rocks forming the base of the succession.

At Martin Head, $30 \mathrm{~km}$ northeast of St. Martins, about $100 \mathrm{~m}$ of cross-bedded yellow and pale red, fluvial and eolian Triassic sandstone beds with intercalated grey and redbrown shales are in fault contact with Carboniferous metasedimentary rocks. Two shale horizons at Martin Head have yielded well-preserved palynofloras. One of these floras is dominated by Patinasporites complex forms, especially Patinasporites densus. Also present are Cycadopites and many bisaccate pollen species, including Brachysaccus sp. This is a Carnian assemblage, although not latest Carnian owing to the abundance of Patinasporites. The other Martin Head palynoflora contains abundant Camerosporites, as well as Cycadopites, Brodispora, Ovalipollis, Samaropollenites and other bisaccates. The abundance of Camerosporites and the presence of Brodispora make late Carnian a likely age assignment and hence correlation with the Echo Cove Formation.

\section{Waterside section}

Near Waterside, on the northwest side of Chignecto Bay (Fig. 3), a series of outcrops consist of massive red sandstone, some red conglomerate, and beds containing abundant red shale rip-up clasts with green reduction rims. These beds also are in fault contact with Carboniferous sedimentary strata. The relatively fine grained nature of the Water- 
side area clastics, as compared to the conglomeratic nature of much of the Echo Cove, Quaco and Honeycomb Point formations, likely indicates that the main source area is the adjacent Carboniferous upland rather than the Precambrian.

\section{Discussion}

The palynomorph dating of the Echo Cove Formation allows correlation of both it and the underlying units to the Wolfville Formation. Although there were no fossils recovered from the Waterside section, its fluvial nature, together with projection from the seismic data from Chignecto Bay, indicate that it correlates to the lower part of the Triassic section and so is equivalent to the Wolfville Formation.

In addition to palynology, other methods have been used to help correlate the scattered early Mesozoic strata in the Bay of Fundy region. Symons et al. (1989) attempted to use magnetostratigraphy to correlate and date outcrop samples. They suggested that the Lepreau and Honeycomb Point formations equate to the lower and upper parts of the Wolfville Formation, respectively and, based on a unit mean paleopole position of $45.3^{\circ} \mathrm{N}, 97.1^{\circ} \mathrm{E}$, that they were likely deposited in the Early Triassic.

The regional relationships of the Triassic outcrops of southern New Brunswick are uncertain. Most of the formations have a prominent northerly dip and are underlain and bounded to the south by Carboniferous or older sequences. When viewed in terms of the offshore seismic profiles, two interpretations are possible. They may represent outliers preserved in north-tilted half grabens ancillary to the main basin-bounding fault, or rotated remnants preserved between reactivated thrust faults during the Mesozoic compressional phase alluded to earlier. However, in view of their proximity to the main Fundy Basin sequences (generally less than $2 \mathrm{~km}$ ), it is unlikely that they represent separate depositional basins.

Our mapping in the subsurface of Fundy Subbasin indicates that up to $3000 \pm \mathrm{m}$ of Wolfville Formation strata were deposited during the time span from ?Anisian to Carnian ( 16 Ma). This yields a maximum rate of accumulation of about $19 \mathrm{~cm} / \mathrm{Ka}$, significantly less than the $83 \mathrm{~cm} / \mathrm{Ka}$ maximum estimate for the Stockton Formation in the Newark Basin (Schlische and Olsen, 1990). The Stockton Formation is equivalent to the Carnian portion of the Wolfville Formation. The lower depositional rate could be due to: (1) under-estimating the maximum thickness of the sequence, (2) over-estimating the time span of deposition, or (3) a sedimentation rate influenced by greater aridity and hence less water inflow into the basin. If the Anisian age assigned to the Carrs Brook section is in error, and the age of the Wolfville Formation is actually Carnian, then the resultant depositional rate is about $60 \mathrm{~cm} / \mathrm{Ka}$.

We have developed a schematic facies model for the Wolfville Formation based in part on the regional models of Olsen (1990) and Smoot (1991) and in part on our field observations and the reflection character of the seismic data (Fig. 20). The model shows the coarse grained, proximal alluvial fan and braided river facies adjacent to the border fault in southern New Brunswick and the finer grained alluvial fan facies on the ramping margin in Nova Scotia, both grading basinward into widespread fluvial facies and ultimately into limited lacustrine units. Scattered eolian facies, examples of which are known from outcrops, are also depicted. Evaporitic units are not shown for the Wolfville formation, but, in view of the increasing aridity toward the end of the Carnian, these may well have occurred once the basin became hydrologically closed.

In summary, the depositional facies represented by the sediments of the Wolfville Formation and its equivalents throughout the Bay of Fundy region reflect the dominant influence on sedimentation of tectonics and, to a lesser extent, paleoclimatic controls. Coarse alluvial fan facies dominate the footwall border fault zone of the asymmetrical half graben basin, and are intercalated with significant fluvial and minor eolian deposits. Within the fan complexes themselves, sequences dominated by more fluvial-related facies may be indicative of changes in the fan slope or in the size of drainage area resulting from border fault motion. During the initial phase of basin formation when it was not yet closed, major axial braided stream complexes flowed eastward to the Orpheus Graben of the Scotian Basin, southwestward toward Georges Bank Basin and possibly northeastward toward the Magdalen Basin. These facies were continuously subjected to subsidence and extensionally driven faulting. From the opposite gently dipping ramping margin, alluvial fan and braided stream complexes deposited poorly sorted, gravels and sands on older basement rocks. These in turn are overlain by thick successions of finer grained fluvial sandstones and sheetflood deposits, again with minor eolian sequences.

\section{Blomidon Formation}

Strata of the Blomidon Formation conformably overlie Wolfville Formation sandstones and represent the first major lacustrine phase of synrift sedimentation in the Fundy Basin. The juxtaposition of extensive sheetflood/playa environments (Blomidon Formation) over primarily alluvial facies (Wolfville Formation) indicates the closing of the rift basin during the Late Triassic and enlargement of the perennial aquatic facies along the basin axis at this time (Fig. 20).

In the type section, at Cape Blomidon on the west shore of Minas Basin, about $315 \mathrm{~m}$ of strata are exposed between the North Mountain Basalt and the Wolfville Formation (Klein, 1962). A fault-bounded section of similar thickness is exposed in sea cliffs on the north side of the Minas Subbasin in the Economy/Five Islands area. At Rossway on Digby Neck, some $400 \mathrm{~m}$ of the formation are present in sea cliffs (Hubert and Hyde, 1982).

The Blomidon Formation was penetrated by both the Chinampas N-39 and Cape Spencer No. 1 offshore wells (Figs. 9, 10), which encountered $1157 \mathrm{~m}$ and $690 \mathrm{~m}$, respectively, of red shale, silty shale, siltstone and occasional sandstone. In spite of seismic ties with the two wells, velocity contrasts between the Wolfville and Blomidon formations are so slight that they cannot be differentiated on ex- 
N.B.

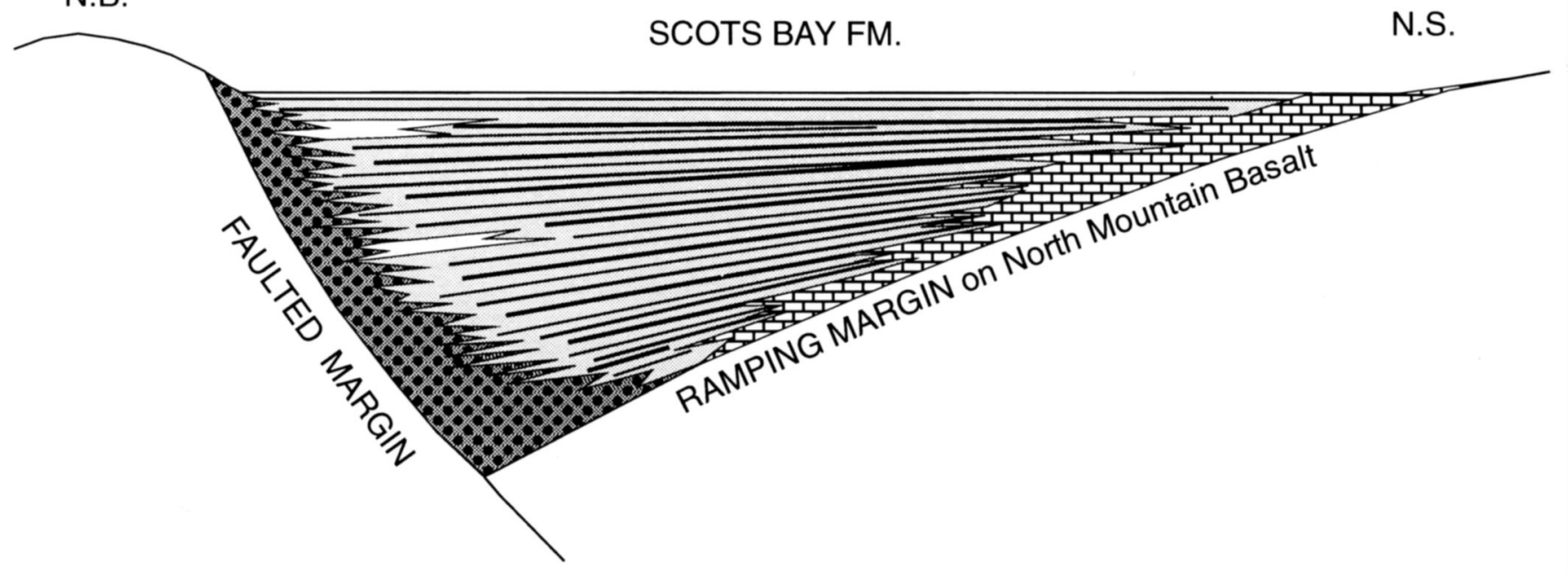

N.B.

N.S.

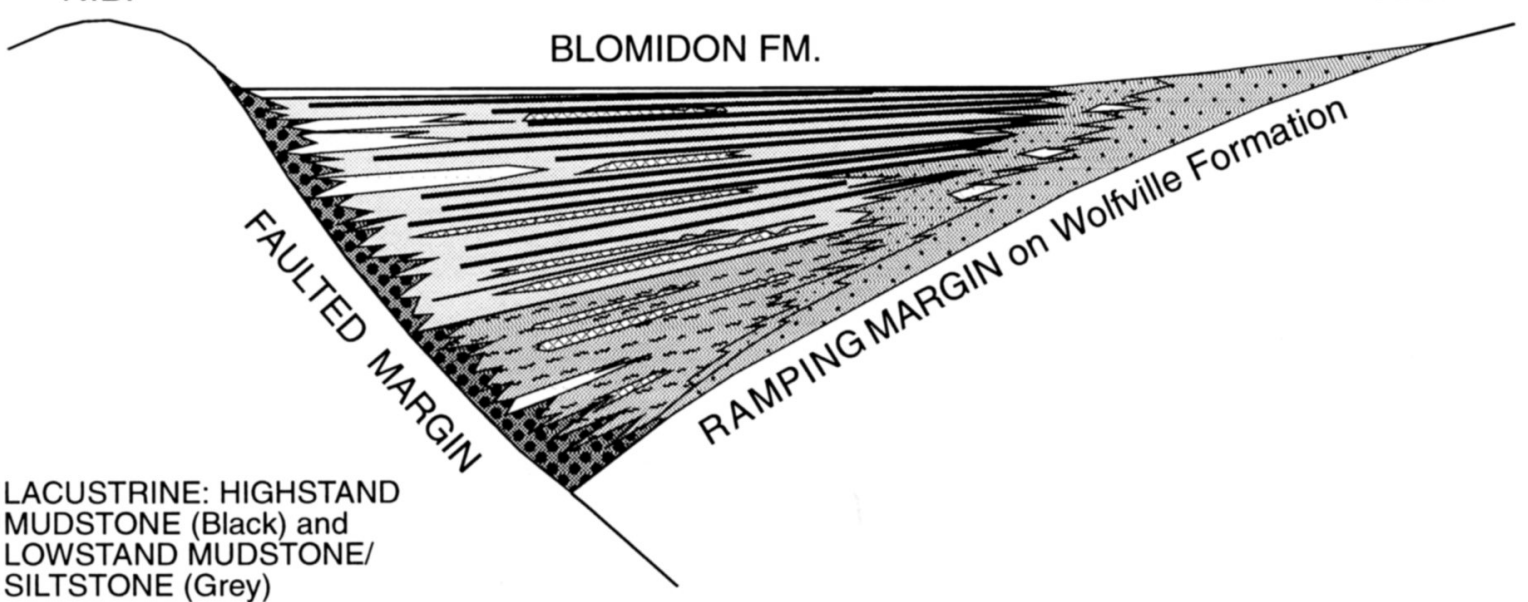

MARGINAL LIMESTONE/

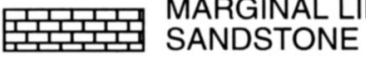

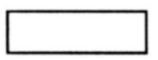

EOLIAN

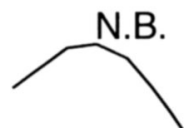

PLAYA EVAPORITE

SAND FLAT TO

PLAYA MUD FLAT

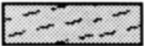

FLUVIAL/LACUSTRINE

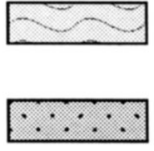

FLUVIAL

ALLUVIAL FAN

(southeasterly source)

ALLUVIAL FAN

(northwesterly source)

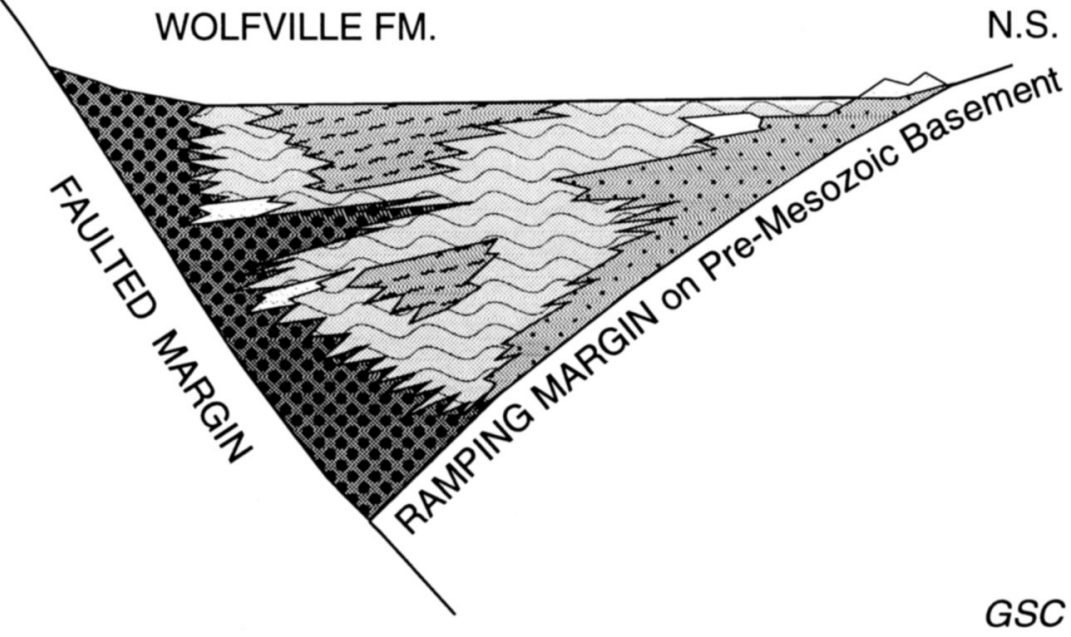

Fig. 20. Schematic facies models - Fundy Basin formations. Not to scale.

isting seismic data. However, an isopach map has been constructed of the interval between the base of the North Mountain Basalt and interpreted basement, i.e., the combined Wolfville and Blomidon formations (Fig. 17). This map shows a northwest thickening wedge that culminates in the Fundy Subbasin with at least $6 \mathrm{~km}$ of strata, half of which is arbitrarily assigned to the Blomidon Formation. However, in Chignecto Subbasin, the interval interpreted as representing the Blomidon Formation thickens substantially into the border fault indicating a period with a higher rate of subsidence and associ- 
ated basin asymmetry (Fig. 12). In this portion of the subbasin the Blomidon Formation is somewhat thicker than the Wolfville.

The Blomidon Formation in Minas Subbasin is exposed at the type section and along the north shore of Minas Basin, discontinuously from Cape d'Or in the west to just north of Bass River in the east (Fig. 3). At Economy Mountain on the north shore, the stratigraphy appears identical to the type section at Cape Blomidon and it is approximately the same thickness. However, the thickness varies considerably when the formation is immediately adjacent to the bounding sinistral Portapique Fault, which was active throughout the period of Mesozoic sedimentation. Olsen (1988b) believed that two significant mudstone cycles seen in the Cape Blomidon type section are also present in the Economy Mountain section $30 \mathrm{~km}$ to the east, thus indicating laterally extensive playa/lacustrine facies in this subbasin. The lack of seismic data precludes an accurate determination of the maximum thickness offshore in the Minas Subbasin, but it is estimated that more than $500 \mathrm{~m}$ occur south of Cape d'Or. Blomidon sediments are absent along the southeastern side of Minas Subbasin, although they probably were present and have long since been removed by erosion. No basin margin outcrops of Blomidon equivalent sediments are recognized in southern New Brunswick.

In outcrop, the Blomidon Formation consists of repetitive cycles of sheet flood/sand flat, playa mud flat and playa lake deposits with some high salinity episodes (Hubert and Hyde, 1982, Jong, 1985; Mertz and Hubert, 1990). Localized zones of slightly more reflective beds within the Wolfville/ Blomidon interval in the Fundy Subbasin indicate possible discontinuous carbonate or evaporite facies. Small scale domino faults, south of Cape Blomidon and in the Five Islands area, are interpreted by Schlische (1990) and Ackermann and Schlische (1993) as collapse features associated with dissolution of evaporites in the Blomidon Formation.

Klein (1962) interpreted a strong gradational relationship between the Blomidon and Wolfville formations. However, based on the study of borehole data from the Annapolis Valley, Jong (1985) indicated a conformable contact between these formations, at least in the eastern part of the region. Correlation between the two offshore wells in the Fundy Basin, and onshore exposures, confirms the conformable nature of the contact.

Mertz and Hubert (1990) related the repetitive cycles of sand flat/playa mud flat/playa lake deposits to periods of shallowing and deepening water which they linked to periodic movement on the basin-bounding fault systems. However, Olsen $(1986,1988 \mathrm{a})$ correlated the cyclical nature of Newark Supergroup sediments in general to the rise and fall of lake levels due to Van Houten or Milankovitch-type orbitally induced climatic cycles.

According to the previously described basin filling models, constant basin subsidence should result in the establishment of a deeper water lacustrine facies along the basin axis. This, generally, is consistent with our interpretation of laterally continuous and gradational fluvial/playa/lacustrine facies throughout Fundy Basin at this time. Such facies are thought to be represented by intervals with uniform and continuous seismic reflections, within parts of the uppermost Wolfville and Blomidon sections in the Fundy Subbasin east of Grand Manan Island, and also by sequences overlying the high amplitude reflections of the Wolfville Formation in Chignecto Subbasin. Similar reflection continuity in playa-lacustrine strata are documented in the Newark Supergroup in other basins (Olsen, 1988b, 1990; Olsen et al., 1989). As discussed above, this continuity is believed indicative of hydrological closing of drainage outflow points; a decreasing volume of sediments reaching the basin; and most importantly, fluctuating climatic conditions from humid to more arid (Schlische and Olsen, 1990; Olsen, 1990).

Powers (1916) reported purple shales beneath the North Mountain Basalt just north of Dark Harbour on the west side of Grand Manan Island. Also, Alcock (1948) reported reddish brown sandstone and conglomerate beneath the basalt in a small area near the north-south trending fault contact with early Paleozoic metasediments on the eastern side of the island. Because neither of these reports appear to have been verified by subsequent studies, they were field checked for this study as possible equivalents of the Blomidon Formation.

The purple shales reported by Powers (1916) are in fact silicified argillaceous siltstones (Wade and Jansa, 1994). Viewed in the microscope, the Dark Harbour samples are light dusky red to light grey, fine to very fine grained, well sorted argillaceous siltstone to silty mudstone. Many samples have a fine to coarse vuggy porosity caused by leaching. Vugs may be lined with 2 or 3 types of crystals, e.g., calcite and possibly gypsum and zeolite. In outcrop, water was observed seeping from several of these leached beds. The diagenetic characteristics of these rocks bear no resemblance to any of the other Triassic/Jurassic sequences associated with the Fundy Basin and are interpreted to be due to the percolation of ground waters enriched in dissolved silica. Based on their lithologic homogeneity, traces of evaporitic minerals and structural conformity to the North Mountain Basalt, they are correlated with the Blomidon Formation (Wade and Jansa, 1994).

The clastics reported by Alcock (1948) were not located. However, a nearby quarry, with recent workings below original ground level, is still in massive basalt.

The Blomidon Formation spans the Norian, Rhaetian and lowermost Hettangian stages (Mertz and Hubert, 1990). Fowell and Traverse (1995), and the present authors, found good palynomorph assemblages in grey mudstones in the uppermost metre of the Blomidon Formation at Partridge Island, on the north flank of Minas Subbasin. Fowell and Traverse (1995) noted that the palynofloras are all Corollina dominated, but minor constituents show that the uppermost assemblages are Hettangian whereas $30 \mathrm{~cm}$ lower in the section, an array of Cycadopites spp. and rare Patinasporites indicate a late Triassic (probably Rhaetian) age. If these conclusions are correct, the Triassic/Jurassic boundary and its associated animal extinctions are circumscribed by this short section at the very top of Blomidon Formation.

Based on a Norian-Rhaetian time span of approximately $15 \mathrm{Ma}$ and an estimated $3000 \pm \mathrm{m}$ of Blomidon Formation in the Fundy Subbasin, a maximum depositional rate (compacted) of $20 \mathrm{~cm} / \mathrm{Ka}$ can be derived. This compares favourably 
with rates for time and facies-equivalent strata from other Triassic rift basins (Schlische and Olsen, 1990). However, it contrasts to the $4 \mathrm{~cm} / \mathrm{Ka}$ and $1.5 \mathrm{~cm} / \mathrm{Ka}$ calculated by Mertz and Hubert (1990) and Schlische and Olsen (1990) for the Blomidon Formation in outcrop due to their very low thickness estimates.

In Fundy Basin, shallow water playa facies dominated during the latest Triassic and had impressive lateral continuity (Fig. 20). It is thought that, given the distribution and thickness of the Blomidon sequence, this playa facies was initially restricted to the basin margins although, by the earliest Jurassic, it probably extended throughout the basin. Evidence for evaporitic beds is present in outcrop at Rossway, Blomidon and Red Head, although their original (and current) volumetric contribution to the Blomidon strata is unknown. Classical deep water, organic-rich lacustrine shales, equivalent to the lower Blomidon, have yet to be encountered, but are interpreted from facies trends to have been modest volumetrically, and restricted to the Fundy and Chignecto depocentres.

\section{North Mountain Basalt}

The North Mountain Basalt is a succession of subaerial, high-titanium, quartz-normative tholeiite flows (Stevens, 1980; Puffer, 1992) that outcrop extensively in Nova Scotia and on Grand Manan Island. It forms North Mountain which bounds the Annapolis and Cornwallis valleys and also occurs in a series of fault blocks along the north side of Minas Basin and on Isle Haute (Figs. 3, 15, 21).

In the Digby Neck area of Nova Scotia, thick, coarse grained, lower and upper basalt flows are separated by 7 or more thin amygdaloidal flows which are rich in zeolites (Papezik et al., 1988). The composite thickness in this area is about $400 \mathrm{~m}$. To the northeast, in the Scots Bay area, up to 16 flows with a composite thickness of about $275 \mathrm{~m}$ are reported (Klein, 1962; Colwell, 1980). The formation was penetrated by the Chinampas and Cape Spencer wells where it is $333 \mathrm{~m}$ and $187 \mathrm{~m}$ thick respectively and by a core hole west of Morden, Nova Scotia, where it is $210 \mathrm{~m}$ (Colwell, 1980). The basalt covers the western two-thirds of Grand Manan Island and is well exposed on the northern and southern extremities of the island in near vertical cliffs up to $100 \mathrm{~m}$ high. In exposures throughout the Bay of Fundy region, columnar jointing is common.

The chemistry of the basalt is very similar to others in the eastern North America flood basalt province and indicates that it was formed during the initial period of extrusion at the time of the rifting of Pangaea (Puffer, 1992). Within about 500,000 years of the initial east coast extrusions, a diversity of chemically distinct basalts were formed which may be related to the onset of seafloor spreading (Olsen and Fedosh, 1988; Puffer, 1992). Schlische and Olsen (1990) believed that the emplacement of the extensive basalts which occur in the Newark Supergroup may be related to a period of increased rate of rift-related extension beginning in the earliest Jurassic.

The North Mountain Basalt is considered by most workers to be earliest Jurassic. Olsen et al. (1989) have even esti- mated that it was formed within $0.200 \mathrm{Ma}$ of the Triassic/ Jurassic boundary. Based on the K-Ar isochron method, Hayatsu (1979) derived a $190.9 \pm 2.4 \mathrm{Ma}$ age for the North Mountain Basalt whereas Hodych and Dunning (1992), using U$\mathrm{Pb}$ zircon dating, determined the age to be $202 \pm 1 \mathrm{Ma}$. They attributed the difference in these ages to be due to a progressive loss of argon from the basalt mineralogy and thus considered the zircon dating the most reliable. The 202 \pm 1 Ma determination fits extremely well with the variously determined $201 \mathrm{Ma}$ date for the Triassic/Jurassic boundary as reviewed by Olsen et al. (1989). It also correlates with the biostratigraphic dating of the Breakup Unconformity (BU) in the offshore rift basins (Jansa and Wade, 1975a; Barss $e t$ al., 1979; Wade and MacLean, 1990). However, it is some 6 Ma younger than the $208 \mathrm{Ma}$ established for the Triassic/ Jurassic boundary by Palmer (1983) and Harland et al. (1990) but only 3 Ma younger than that determined by Gradstein $e t$ al. (1994) (Table 1). Not withstanding problems with absolute age of the basalt, its relationship with BU, and its proximity to the Triassic/Jurassic boundary, paleontological data from the Blomidon Formation, described above, indicate the age of the formation to be earliest Hettangian occurring as it does only a metre above the interpreted Triassic/Jurassic boundary within the Blomidon Formation (Fowell and Traverse, 1995; Olsen et al., 1989). A possible solution to this conundrum is a significant hiatus between these formations, although all workers report a structurally conformable relationship.

Well and seismic data confirm that the North Mountain Basalt is widespread in the subsurface of Fundy Basin (Figs. $5,15,21)$. The seismic character of the formation may reflect its regional makeup of two massive layers and an intervening amygdaloidal sequence. There is an irregular internal reflective zone which may be generated by the lower velocity, variably porous, amygdaloidal unit (Fig. 16). In most areas the basalt forms a prominent reflective zone between the adjacent clastic sequences. However, where it occurs shallower than 0.7 to $0.8 \mathrm{Sec}$., two-way-time $(<\sim 1000$ $\mathrm{m}$ ), it is typically very difficult to detect (Figs. 9, 10); for this reason, the northern limit of the basalt is somewhat uncertain.

In some parts of the basin, the North Mountain Basalt can be traced northward into the hanging wall of the first fault of the boundary fault system but is not recognized in the footwall block (Fig. 4, sections b-b', c-c', Figs. 5, 22). This may be due to structural complexity in the footwall block, to erosion, or possibly non-deposition. As described above, the scattered outcrops of Mesozoic strata in southern New Brunswick are all considered equivalent to the Wolfville Formation; therefore, the lack of North Mountain Basalt in these areas may be due to either non-deposition or erosion.

The ponded nature of the two massive flows in the Digby Neck area, reported by Papezik et al. (1988), is supported by the seismic data. Figure 21, the isopach map of the North Mountain Basalt, shows a southwesterly thickening of the formation along Digby Neck and rapid northwesterly thickening into Fundy Subbasin. Just east of the Grand Manan Fault, the formation is 600 to $>1000 \mathrm{~m}$ in thickness whereas, over most of the basin it averages 400 to $500 \mathrm{~m}$ thick. 


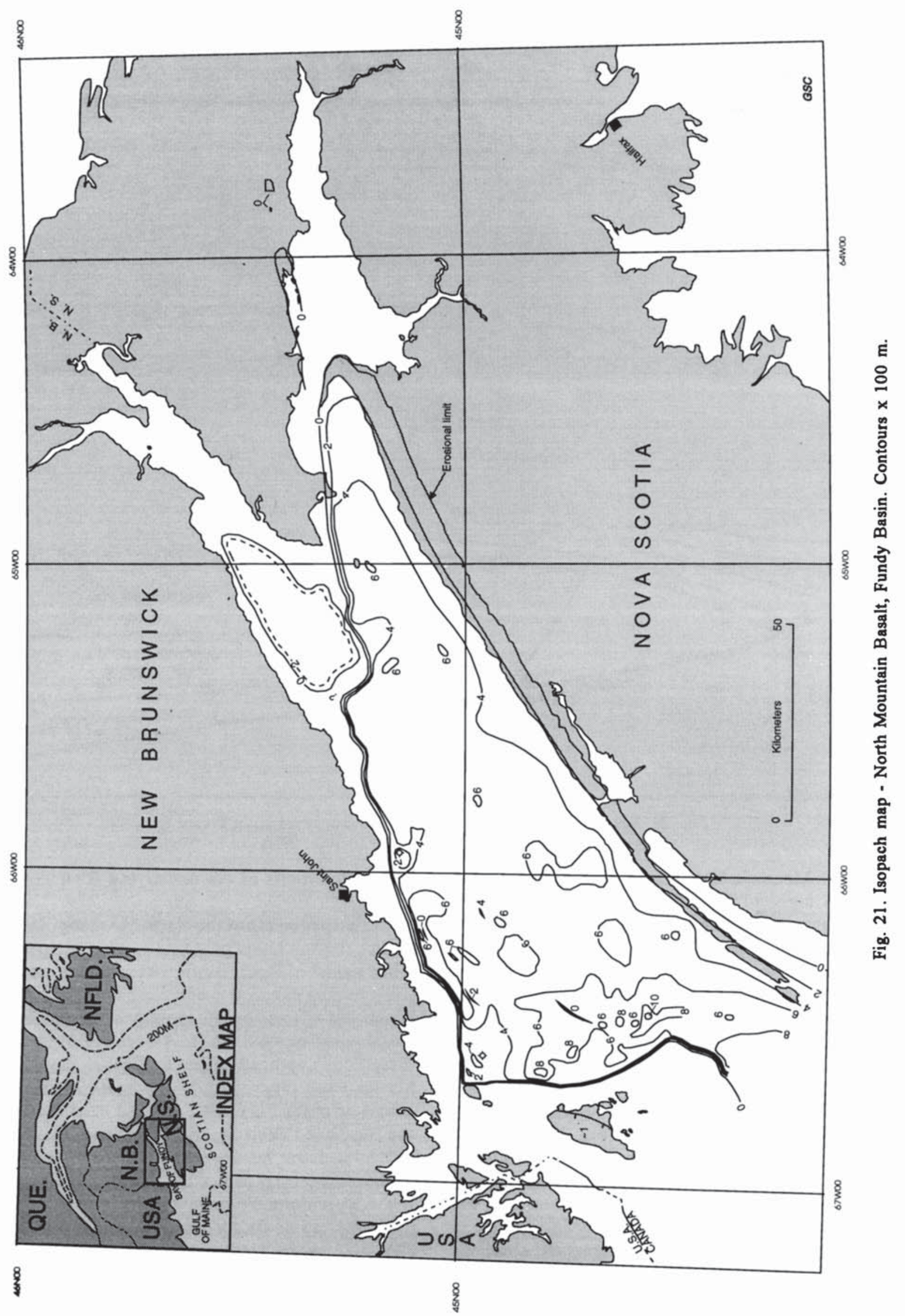




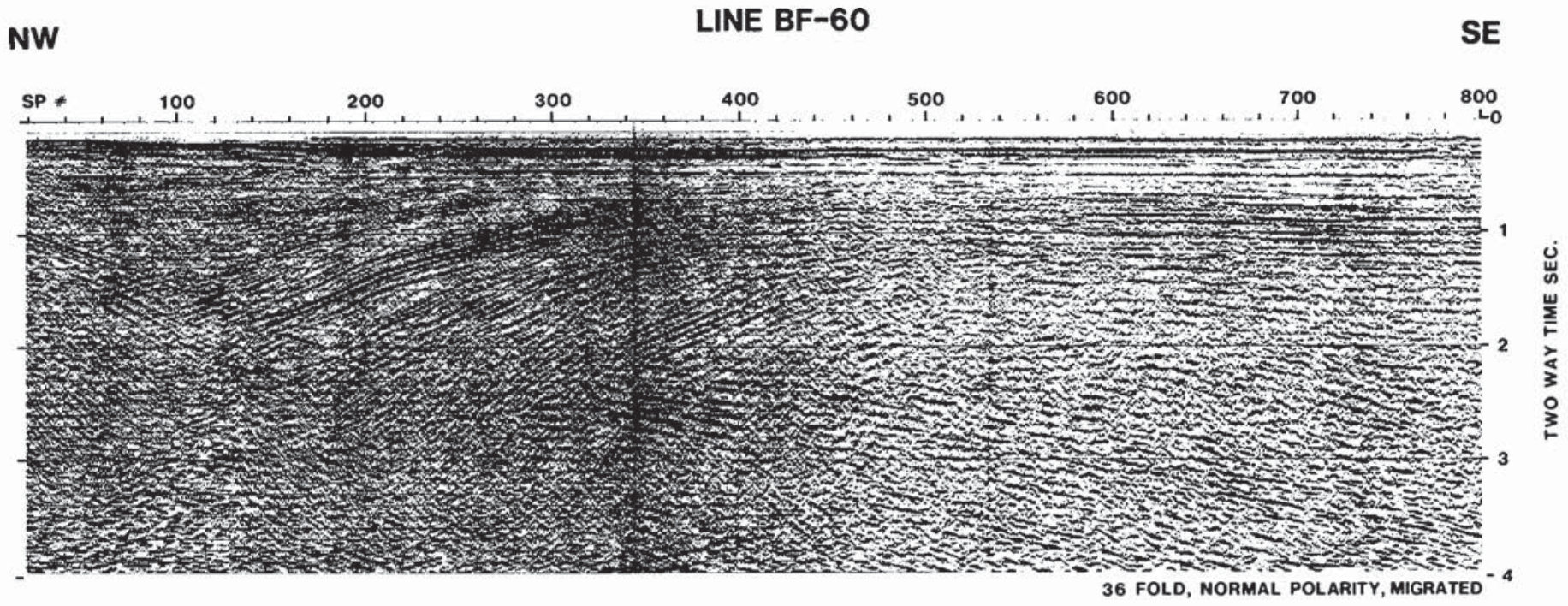

$\underset{2}{\text { KILOMETRES }}$

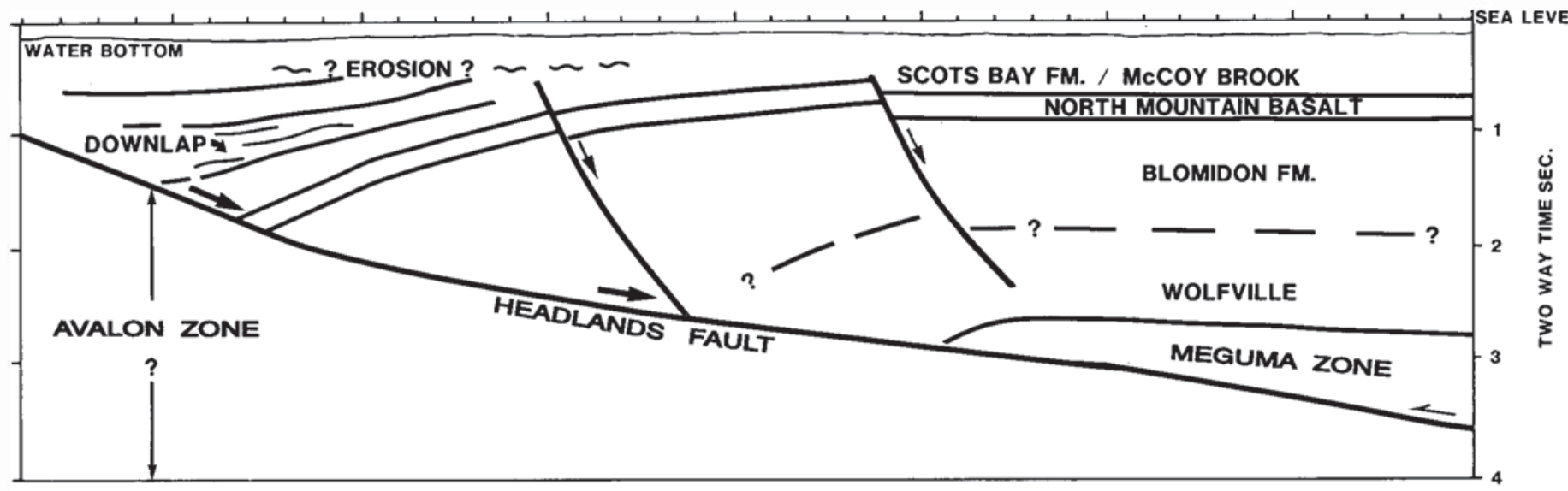

Fig. 22. Seismic section and line drawing BF-60. Location in Figure 3.

The North Mountain Basalt is picked with some uncertainty in the Chignecto Subbasin. In this area, the distinctive seismic character found in the Fundy Subbasin is absent but the reflection from the basalt can be jump-tied, across the Cobequid Fault zone, to the Triassic ' $A$ ' marker of Brown (1986). The change in seismic character may be attributed to the relatively shallow depth of the reflector, as discussed above or, perhaps, to a thinner sequence of basalts. A third alternative is that the basalt was not deposited in this area.

In Minas Subbasin, the North Mountain Basalt currently is limited to the area west of Cape Blomidon and scattered remnants along the Portapique Fault (Fig. 15). However, the exposures along the faulted north shore of Minas Basin from Bass River west to Cape Sharp suggest the basalt originally covered most of the subbasin, thinning to the east, and was subsequently eroded. The north shore exposures of basalt and younger strata exist as erosional remnants. Similarly, the southern extremity of the formation in the Annapolis Valley has been eroded. However, when considering the relatively short time of extrusion, and the observed axial thickening due to ponding, it is unlikely that the basalt extended much beyond the limits of the underlying Blomidon Formation (Fig. 23).

Contours on top of the North Mountain Basalt (Fig. 15) outline the southwest plunging somewhat asymmetric synclinal nature of Fundy Basin. The southeast limb has a relatively smooth dip of $\sim 6$ to $8^{\circ} \mathrm{NW}$ whereas the northwest limb, which was affected by late movement on the Grand Manan/ Headlands/Cobequid faults, is more highly structured. The formation is vertically offset by $1 \mathbf{~ k m}$ or more at the Grand Manan Fault (Figs. 5, 15). The basalt is eroded over the extension of the Cobequid Fault and, near the junction with the Headlands Fault System, there may be stacking of the formation due to subsequent reverse movement of the faults. In the west-central part of the Bay, as described earlier, the relatively uniform dip slope is interrupted by a flexure which drops the top of the formation by about 0.20 to $0.25 \mathrm{Sec}$. (300-400 m) (Fig. 16).

The feeder system for the North Mountain Basalt is not seen on either reflection seismic or existing magnetic data. From the areal distribution and relative uniformity of the formation, a narrow fissure system source is indicated rather 


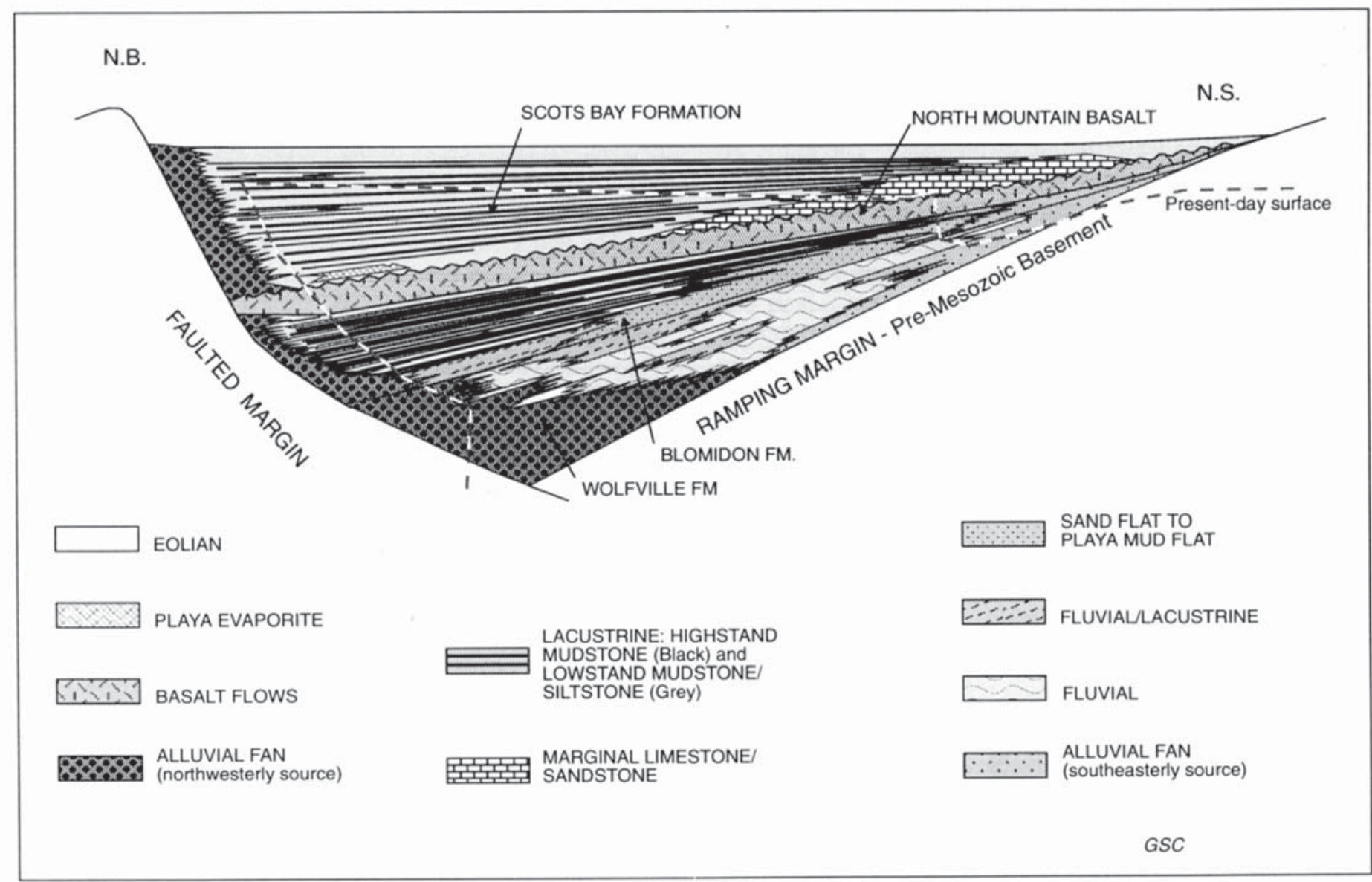

Fig. 23. Composite facies models and basin filling relationships, Fundy Basin. Not to scale.

than the point sources (vents) interpreted by Stevens (1980). Two Triassic/Jurassic basaltic dykes are known to occur adjacent to Fundy Basin. The largest, Shelburne Dyke, 100 $\mathrm{km}$ to the southeast, extends along the south shore of Nova Scotia for some $200 \mathrm{~km}$ (Papezik and Barr, 1981). The second, Minister Island Dyke (Stringer and Burke, 1985) is exposed intermittently for $15 \mathrm{~km}$ along the north side of Passamaquoddy Bay, New Brunswick about $30 \mathrm{~km}$ northwest of the junction of the Grand Manan and Headlands faults (Figs. 6, 15).

Aumento (1966) and Keppie (1992) have suggested the chemically similar Shelburne Dyke as the possible feeder dyke for the North Mountain Basalt. From a regional standpoint, if this were the case, then the hinge zone of Fundy Basin would have to lie to the southeast of the dyke and the entire southwestern part of Nova Scotia and much of the adjacent continental shelf would have been covered with Triassic sediments as well as flood basalts. This is unlikely because: (1) southwestern Nova Scotia was a highland (sediment source area) at the time; (2) the clastic facies on the ramping margin are not indicative of distant transport; (3) no remnants of sediments or flows occur south of South Mountain (Keppie and Muecke, 1979); (4) only small percentages of basalt clasts occur in tills in western Nova Scotia (Boner et al., 1989; Finck et al., 1989, 1990; P. Finck, personal communication, 1991); and (5) there is a minimum of basaltic fragments in the thick siliciclastic formations of the Scotian Basin which were sourced in part from the uplands of Nova Scotia (Jansa and Wade, 1975a).

Similarly, the relatively small size of the Minister Island Dyke and its distance from Cobequid Bay make it an unlikely source of the North Mountain Basalt.

Evidence of a feeder dyke may occur in outcrop at Old Wife Point in Minas Basin, where a $40 \mathrm{~m}$ wide zone of tectonized columnar basalt rises from the shore. The basalts are in fault contact with the Scots Bay Formation on the west and exposures of North Mountain Basalt capping Economy Mountain on the east. Powers (1916) and Stevens (1980) interpreted the section as a fault-bounded dyke within down-faulted North Mountain Basalt. Donohoe and Wallace (1982) mapped it as a fault bounded block, but not all the evidence supported this interpretation (P. Wallace, personal communication, 1992). Schlische (1990) described this exposure as a series of rotated normal faults, whereas Olsen and Withjack (1994) interpreted it as a secondary feature in a divergent/ convergent strike-slip fault zone.

In summary, there are two possible locations for a feeder system within the basin: the Grand Manan Fault System or in the vicinity of the basin axis. The thickening of the formation toward the Grand Manan Fault, and the approximate north-south trend of this thickening along the fault (Fig. 21), might indicate this fault system to be the source of the basalts. However, studies in the Newark-type basins show the border faults are not the conduits for the lavas and 
that the feeder dykes probably lie along the basin axis or the ramping margin (Manspeizer, 1980, 1988). Nowhere are they seen in exhumed border faults. Also, the occurrence of the formation for more than $220 \mathrm{~km}$ updip to the northeast of the Grand Manan Fault may be a problem for a feeder located along the western side of the basin. Therefore, although there is no unequivocal physical evidence defining this fissure system, circumstantial evidence and comparison with other Newark-type basins suggest that it is probably located toward the northern side of Cobequid Bay, passing between Cape Split and Cape Sharp/Partridge Island, extending southwestward to the vicinity of Grand Manan Island. This is consistent with emplacement models discussed by Papezik et al. (1988). Thickening of the basalt adjacent to the Grand Manan Fault would be the result of ponding due to basin geometry/paleotopography with 100 to $300 \mathrm{~m}$ of subsidence (tilting) indicated during the period of emplacement.

\section{Scots Bay Formation}

Following the emplacement of the last of the North Mountain Basalt flows, the surface of Fundy Basin was a relatively flat, emergent basaltic plain stretching from, or near, the present day New Brunswick coast, southward to onlap the Meguma upland of western Nova Scotia and from the eastern reaches of Cobequid Bay to the west of Grand Manan Island. It was on this surface that the Scots Bay Formation was deposited. Deposition probably initiated in a small structural basin, coincident with the depocentre of Fundy Subbasin, and quickly spread to include most of the southern part of Fundy Basin. The northwesterly control on the early Scots Bay depocentre appears to have been a down-to-the-east fault zone extending north-northeastward from the Grand Manan Fault (Figs. 15, 16). Relief across this fault probably served to separate early lacustrine facies to the southeast and terrestrial facies to the northwest.

The type section of the formation occurs in six small remnant synclines in the Scots Bay area, where it unconformably overlies the North Mountain Basalt (Figs. 3, 7, 24). In its type section, the formation is about $8 \mathrm{~m}$ thick and consists of a series of interbedded limestone, silty and cherty limestone, sandstone, siltstone and shale which were deposited in a dominantly lacustrine environment. The limestones frequently contain silicified tree remains and siliceous tufa (Thompson, 1974; Birney-De Wet and Hubert, 1989).

Stratigraphic equivalents, approximately $250 \mathrm{~m}$ thick (Tanner, 1990), designated the McCoy Brook formation (Donohoe and Wallace, 1978), occur as fault-bounded remnants in the Economy/Parrsboro area of Minas Basin. Although never formally introduced as a formation (Williams et al., 1985) the McCoy Brook terminology has received wide acceptance among researchers working on the north shore of Minas Basin.

The McCoy Brook formation consists of a variety of terrestrial facies including talus breccia, alluvial fan, fluvial sandstones and mudstones, lacustrine sandstones and shales, and eolian dunes (Tanner, 1990). Like the Scots Bay Formation, these sediments were deposited directly on the surface of the basalt. However, in the type-section area along the Portapique Fault, the surface of the underlying basalt was highly irregular due to early post-basalt tectonism, possibly indicating crustal adjustments following the depletion of the magma source. The resultant complex facies distribution, as observed in outcrops of the McCoy Brook formation, reflect the influence of the depositional surface upon sedimentation.

The Scots Bay Formation and its equivalents are widespread offshore in the basin, but no separation of facies is possible from the seismic data. Continuity exists, through the network of seismic profiles, from near the type section westward to the Headlands and Grand Manan faults (Fig. 24). Reflections from within the Scots Bay Formation are weak and discontinuous but indicate general conformity with the North Mountain Basalt in the central part of the basin and minor onlap toward the margin. The occurrence of the formation in the erosional outlier in Chignecto Subbasin, as shown in Figure 24, is based on correlation of seismic data from both sides of the extension of the Cobequid Fault. The northeastern limit is speculative.

Approximately $357 \mathrm{~m}$ and $169 \mathrm{~m}$ of McCoy Brook-like sediments were encountered in the Chinampas and Cape Spencer wells, respectively. There the lithology is predominantly red-brown gypsiferous shale with thin interbeds of red to pink siltstone, sandstone and pebble conglomerate.

The seismic data indicate that more than $2500 \mathrm{~m}$ of postNorth Mountain Basalt strata remain in the Fundy Subbasin (Fig. 24). Although the minimum age of the sequence is unknown, for the purpose of description, it is all included as Scots Bay Formation. The lower $\sim 1000 \mathrm{~m}$ of Scots Bay Formation in the initial depocentre is seismically transparent and may represent thick deposits of lacustrine shale. The overlying beds are weakly reflective throughout the basin and are interpreted to represent alternating coarse and fine grained lacustrine facies, playa and fluvial facies. Within the overall basin stratigraphy, this formation represents the most widespread continuous lacustrine facies (Figs. 20,23).

Erosion of up to $2 \mathrm{~km}$ of the Scots Bay Formation at the seafloor and along the south side of the bay can be documented using the seismic profiles (Figs. 9, 10, 12, 16). Extrapolation of beds indicates an original depositional limit along South Mountain. Adjacent to the Headlands Fault System, the Scots Bay Formation has been deformed into a series of en echelon thicks and thins, by post-depositional (?Mid Jurassic) inversion of the various fault slices, and considerable erosion occurs on some of the anticlines (Figs. 9, 10, 22). The positive structures were originally interpreted as rollover anticlines (Brown, 1986), but our subsequent analysis indicates they cannot be formed in that manner. This is supported by a recently published analysis by Withjack et al. (1995). Neither the amount of structural inversion nor the amount of sediment removed by erosion is known but both may be significant. The thickening of beds away from the anticlines and toward the Headlands Fault System indicates syndepositional movement and probable local erosion and redeposition of early Scots Bay sediments (Fig. 22). At least $2 \mathrm{~km}$ of the formation has been eroded at the junction of the Cobequid and Headlands faults. Finally, this study by Tanner (1990) 


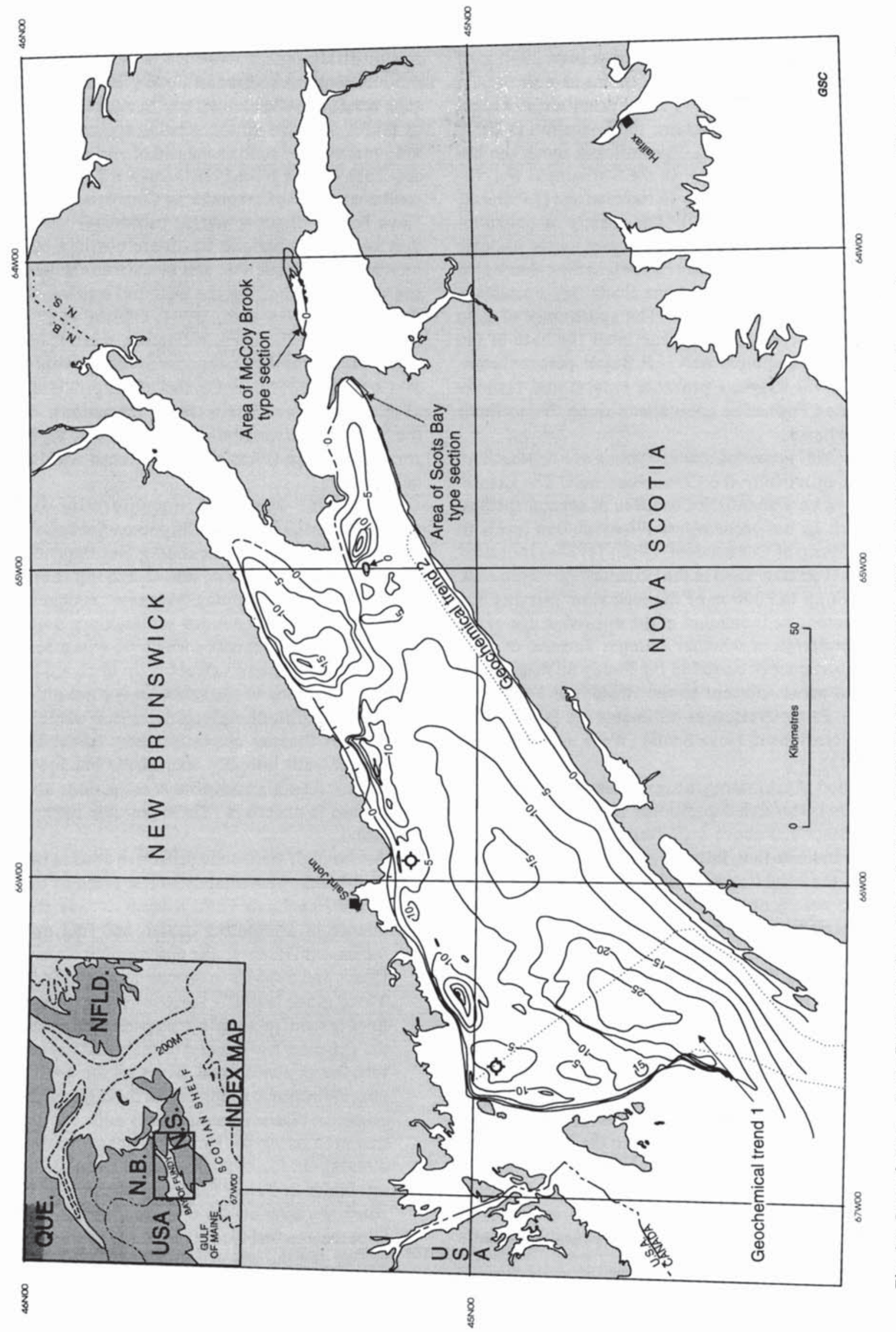

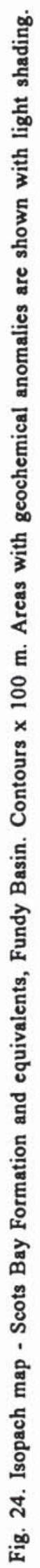


of the diagenetic history of the formation in the McCoy Brook area indicates that up to $2 \mathrm{~km}$ of erosion has occurred in that region; Olsen (1993) noted that thermal history indicators for the U.S. rift basins suggests that at least $2000 \mathrm{~m}$ of section has been removed from these basins as well.

The age range for the Scots Bay Formation is uncertain. Based on macrofossil content, the formation is Early Jurassic (Olsen, 1981, 1988a). Palynofloras above the basalt, at about 1100 feet $(335 \mathrm{~m})$, in the Chinampas well indicate an Early Jurassic, probably Hettangian age (J.P. Bujak, personal communication, 1979). The variety of paleontological and radiometric analyses cited previously indicate that the underlying North Mountain Basalt is earliest Hettangian in age. Therefore, deposition of the Scots Bay Formation can be dated as early Hettangian. The appearance of Late Triassic palynomorphs reported from near the base of the formation in the Chinampas well (J.P. Bujak, personal communication, 1979) suggests probable erosion and reworking of Blomidon Formation equivalents along the northern margin of the basin.

Traverse (1987) reported strata as young as Pliensbachian in cuttings samples from the Chinampas well. The Liassic age depends on very abundant Corollina of several species, some of which do not occur below Pliensbachian levels in the Hartford Basin of Connecticut. Olsen (1988a) indicated Pliensbachian-Toarcian strata in the Economy/Parrsboro area. However, with up to $2000 \mathrm{~m}$ of the formation missing due to erosion, there is no indication of the minimum age of the Scots Bay Formation or whether younger Jurassic or even Cretaceous units once occurred in the Fundy Subbasin or in overthickened areas adjacent to the Headlands Fault System (Fig. 24). Early Cretaceous sediments are known from a number of locations in Nova Scotia (Wade and MacLean, 1990, fig. 5.42).

One method of estimating the minimum age of the Scots Bay Formation is through depositional rates. The basin filling models described above and illustrated in Figures 20 and 23 would indicate that, following the reduction of stream gradient and the establishment of lacustrine facies, accumulation rates were generally lowered. The $\sim 2500 \mathrm{~m}$ of Scots Bay section remaining in Fundy Basin ranges in age from early Hettangian to at least Pliensbachian, a time span of about $17 \mathrm{Ma}$ and a depositional rate of about $15 \mathrm{~cm} / \mathrm{Ka}$. This is less than the 19 to $20 \mathrm{~cm} / \mathrm{Ka}$ rate calculated for the Wolfville and Blomidon formations. Applying the $15 \mathrm{~cm} /$ $\mathrm{Ka}$ rate of deposition to the estimated $4500 \mathrm{~m}$ for the complete Scots Bay Formation yields a time span of $30 \mathrm{Ma}$ or a minimum age of about mid Aalenian (Fig. 7). Considering the assumptions, this compares favourably with the mid Bajocian top for the coeval Mohican Formation in the Scotian Basin (Wade and MacLean, 1990) and may indicate that the two basins were still tectonically linked in the Mid Jurassic. However, until better age data are obtained, perhaps from cores of subcrops of these strata, the age of the youngest sediments in Fundy Basin will remain speculative.

\section{Chignecto Subbasin}

In the subsurface of Chignecto Subbasin (Fig. 1), the seismo-stratigraphic sequence is somewhat different from that observed elsewhere in Fundy Basin. Deep, sub-Mesozoic zones of reflective strata, bounded by unconformities or faults, are seen on the seismic sections. The reflections are somewhat discontinuous and of variable amplitude. This sequence can be traced northeastward toward the offshore continuation of the Carboniferous Cumberland Basin of northern Nova Scotia. Shallow marine carbonates and evaporites of that age in Cumberland Basin are overlain by a thick succession of fluvial deltaic and lacustrine clastics which were sourced generally from the west and southwest (Howie and Barss, 1975; Ryan et al., 1991; Gibling et al., 1992). It is suggested that the deep, reflective, seismic sequences beneath the Mesozoic Chignecto Subbasin strata may represent several depositional cycles of the proximal equivalents of the Cumberland Basin clastic formations. Alternatively, the bounding seismic reflections might be representative of several Variscan thrust slices developed within Carboniferous strata.

The base Mesozoic unconformity is correlated northwestward across the Chignecto Subbasin to its termination against the basin bounding Headlands Fault System, a maximum distance of $25 \mathrm{~km}$. Overlying the unconformity is a northwesterly dipping Mesozoic wedge consisting of three unconformity-bounded sedimentary sequences (Figs. $12,25)$. The lower sequence which we equate to the Wolfville Formation and its equivalents is up to about $1500 \mathrm{~m}$ thick. In the axial region of the subbasin it contains some high to very high amplitude reflections which exhibit some local wedging or lensing characteristics. These grade into or interfinger with laterally continuous but lower amplitude reflections. The high amplitude reflections are unique and their cause is uncertain. Three possible interpretations are suggested.

(1) As the high amplitude reflective zone is in the hanging wall block, immediately to the south of an active slice of the Headlands Fault System, it may represent a sequence of alternating coarse and fine grained fluvial facies, equivalent to the outcropping Honeycomb Point, Quaco and Echo Cove formations of the St. Martins area. These grade laterally (southward) into the less well defined or more seismically transparent units which transgress the ramping margin and probably represent distal alluvial fan to sheet flood facies of the Wolfville Formation. Palinspastic restoration of the high-amplitude seismic sequence places it immediately adjacent to the St. Martins area outcrops. However, coarse grained proximal alluvial fan facies should be common along the boundary faults in Fundy Subbasin but no similar reflective zones are seen on the seismic profiles. This may reinforc the interpretation of the St. Martins area as a structural corner and the site of anomalous sedimentary units. 


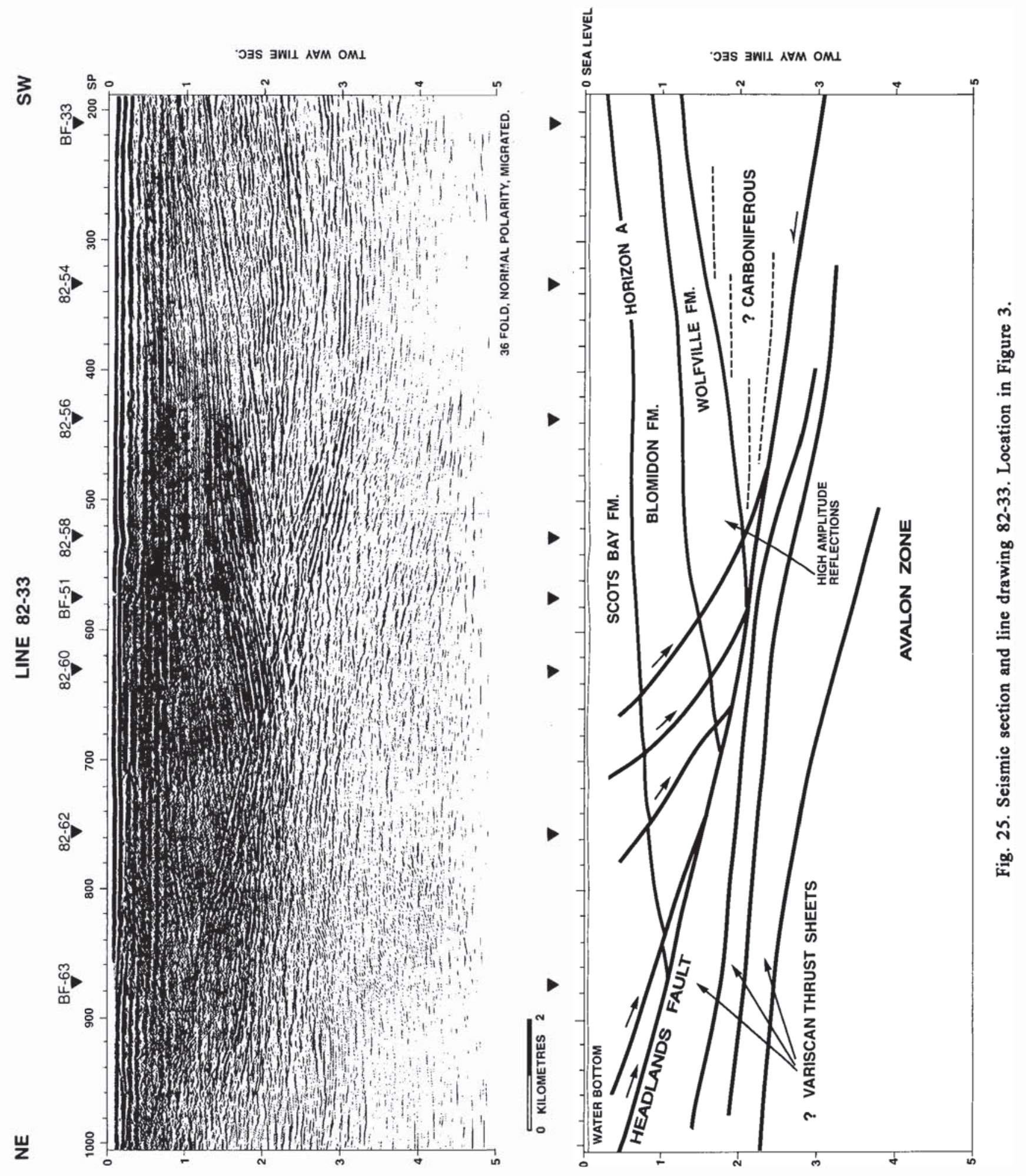


(2) Alternatively, the reflective zone may represent a unique facies within the Wolfville Formation, not seen elsewhere in the basin, such as either carbonates or evaporites within a repetitive clastic lacustrine facies. Similar type reflections, in a similar basin position, define the well studied Lockatong Formation lacustrine facies in the Newark Basin (Reynolds and Olsen, 1994) and are seen on the NORPAC NB-1 seismic line (Olsen and Kent, 1992), where they are correlated with organic rich calcareous mudstones interbedded with shallower lacustrine facies. The development of a local restricted lacustrine environment during deposition of the Wolfville Formation would require closure of the Chignecto Subbasin against the (south-bounding) transform fault zone. This condition is not supported by the seismic data which show basement-parallel reflections uplifted and eroded by post depositional movement of the fault. Although a subtle closure may not be evident, closure sufficient for development of deep lacustrine facies is unlikely. Also, since the reflective beds extend to the base of the Wolfville Formation, the lack of fluvial facies in this area would have to be explained.

(3) A third possible interpretation is that the high-amplitude succession and its lateral equivalents may not be Wolfville Formation but rather represent interbedded ?late Permian carbonate and clastic or even coal-bearing facies not seen elsewhere. Although this might explain the unconformities seen at the base and top of the sequence, it is the least favoured interpretation.

The facies contained in the middle wedge have an onlap relationship in the axial part of the basin with the lower unit and exhibit some gentle thinning on the ramping margin. The seismic reflections, generally, are of lower amplitude and retain their lateral continuity from the fault to subcrop. The unit is thickest against the fault in the southwestern part of the subbasin indicating maximum subsidence and transport toward that area. The very uniform nature of the seismic character of this unit suggests widespread successions of shale, siltstone and sandstone of the Blomidon Formation. A fluvial/lacustrine environment is interpreted.

As mentioned, the typical Fundy Basin-North Mountain Basalt reflection package is not recognized in this subbasin and the boundary between interpreted Blomidon and Scots Bay formations is placed at the prominent Horizon A which appears to be time equivalent with the basalt. The Scots Bay Formation or its equivalent is a weakly reflective unit with only faint indications of internal bedding due primarily to the strong water-bottom multiple train in the seismic data. Like the underlying Blomidon Formation, it thickens substantially into the Headlands Fault System indicating syntectonic deposition. The maximum remaining thickness of Scots Bay Formation in this subbasin, as indicated on Figure 24, is approximately $2.2 \mathrm{~km}$.

\section{Petroleum geology}

In comparison with other sedimentary basins in North America, little attention has been given to the hydrocarbon potential of sediments in the east coast Triassic/Jurassic rift basins. Sporadic exploration in several of the larger basins of the Newark Supergroup have recorded occurrences of hydrocarbons, although none have not been commercially produced (Bowman et al., 1987). Based on data from the Newark and Fundy basins, Olsen (1988a) described six depositional environments associated with Early Mesozoic rift basins. The most significant of these from the standpoint of petroleum source rocks are the deep-water (anoxic) lacustrine and swamp environments, whereas reservoirs will most likely occur in adjacent and overlying fluvial, deltaic and shallow lake facies. In Fundy Basin, seismic data, well results, and recent field studies provide an improved understanding of basin evolution and thermal history and indicate that this basin should be considered prospective for hydrocarbon generation and trapping. Following is a review of the elements and processes necessary to generate and trap hydrocarbons as related to the sedimentary succession in Fundy Basin.

\section{Hydrocarbon source rocks}

Throughout most of the Newark Supergroup, organicrich deep lacustrine shales are considered the best source for hydrocarbons (Katz et al., 1988; Olsen, 1988a, 1990; Kruge et al., 1990). These formed most often in the axial portion of the rift adjacent to the basin bounding fault. Over time, the lacustrine facies expanded and, at their maximum extent, produced widespread conditions favourable for the preservation of organic matter. Depending on the size of the basin and period of evolution, the lakes covered areas of a few tens to several thousand square kilometres, although the majority of them were several hundred square kilometres in size (Schlische and Olsen, 1990; Smoot, 1991).

In Newark Basin, the lacustrine strata were deposited in stacked sequences of repetitive, shallowing-upward sedimentary cycles of black shale, grey to red mudstone and limestone "Van Houten cycles"; (Olsen, 1985, 1986). The black shales define the base of the sequence; represent periods of maximum water depth (highstand); and have the greatest amount of preserved organic matter. The total organic carbon (TOC) values of these sediments can be up to $20 \%$, although the average values for most shales are in the range of 1 to $3 \%$ (Olsen, 1985).

As discussed previously, Olsen (1990) assigned all of the basins of the Newark Supergroup to one of three types based on their sequences of preserved lacustrine facies. These facies in turn reflect the prevailing climatic conditions at the time of deposition and are thought to imply a south to north trend of increasing aridity. Deep water organic-rich shales are found in both Richmond-type (water inflow exceeds outflow) and Newark-type (inflow equals outflow) basins. In contrast, sediments in the Fundy-type basins are deemed to reflect semi-arid conditions, where water outflow exceeds inflow, with resultant prevalence of thin, sandy playa facies.

When compared to the observed features of Fundy Basin, the authors have some reservations regarding Olsen's (1990) "Fundy-type lacustrine facies complex". Our model 
would anticipate, without considering quality, that the smallest proportion of lacustrine facies occurs in the Wolfville Formation and largest in the Scots Bay. We concur with the interpretation that during Blomidon time climatic conditions were relatively dry and that playa facies were likely widespread. Based on our mapped formation thickness and basin geometry, we believe that deeper water lacustrine facies existed in the Fundy Subbasin, and probably in the Chignecto Subbasin as well. Schlische and Olsen (1990) interpreted the playa facies as reflecting continuous low subsidence rates and a very low sedimentation rate of about 1.5 $\mathrm{cm} / \mathrm{Ka}$. However, as demonstrated above, seismic, biostratigraphic, and borehole data indicate that sedimentation rates of $\sim 20 \mathrm{~cm} / \mathrm{Ka}$ occurred in the thicker parts of the basin.

The highly oxidized nature of the fluvial and intermittent eolian and evaporitic (playa) facies of the Blomidon Formation, which are exposed along the basin margin, together with their small amounts of organic carbon would, at first glance, suggest poor source rock potential (Jong, 1985). However, Mertz and Hubert (1990) suggested that the red shales at the base of each of the Blomidon's 1.5 to $2.0 \mathrm{~m}$ sedimentary cycles (cycle mode $=1.3 \mathrm{~m}$ ) are representative of marginal, shallow water, perennial lacustrine sedimentation, and that there likely were significant advances and retreats of the lake shorelines. Therefore, with the higher rates of deposition and thicker sedimentary section indicated by the seismic data, and combined with the presence of playa to shallow lacustrine facies along the margin of the basin, it can be envisioned that the lacustrine strata would thicken towards the basin centre, some $30 \mathrm{~km}$ to the northwest, and that deep and permanent lakes would occupy this position (Fig. 20). If this interpretation is correct, then playa facies are less widespread in the Blomidon Formation than has been postulated and evaporitic sequences correspondingly less common.

The seismic data from Fundy Basin indicate that the most extensive and deepest water lacustrine facies should occur in the area just east of the Grand Manan Fault. During deposition of the Wolfville and Blomidon formations, the extent of the lacustrine facies in this area may have fluctuated roughly between the 4.0 and $5.0 \mathrm{~km}$ isopach lines on Figure 17 with deep water and possibly anoxic environments limited to the smaller areas of closure. In Chignecto Subbasin, the most prospective area will be within the $3 \mathrm{~km}$ isopach on this figure.

The hypothesized deep lacustrine Blomidon strata have been buried to depths $>5000 \mathrm{~m}$ in the Fundy Subbasin. The organic material in these facies would be mature to overmature and any generated liquid hydrocarbons may have been thermally cracked and/or destroyed. However, our preliminary modelling of the thermal history of the basin suggests that, in the Chignecto Subbasin, the Blomidon Formation is somewhat less mature and may still be in the main stage of hydrocarbon generation. Additionally, if the high amplitude reflections within the Wolfville Formation in the northwestern part of this subbasin represent lacustrine facies, at least a portion of these may still be within the late oil window and capable of generating and expelling liquid hydrocarbons.
Although limited carbonaceous plant material has been found onshore, in outcrops of Scots Bay/McCoy Brook sediments, extensive faunal assemblages, including both terrestrial and aquatic forms, occur (Birney, 1985, Olsen, 1988a, Tanner, 1990). These, together with lacustrine algae and other micro-organisms and plant material, would form the basis of organic rich source beds. Scots Bay strata are at the other end of the maturation curve and thus subjected to a maximum burial of only about $4.5 \mathrm{~km}$ or a modelled temperature of about $115^{\circ} \mathrm{C}$ (see below). Any organic material in these lacustrine sediments would thus have a greater opportunity for preservation and an enhanced potential to generate hydrocarbons. During deposition of the Scots Bay Formation, the deeper lacustrine facies probably more closely coincided with the $1500 \mathrm{~m}$ isopach lines on Figure 24 .

Lacustrine facies rich in telalginite and amorphous organic material are capable of generating large amounts of oil and, given suitable reservoir facies and trapping mechanisms, may lead to significant quantities of pooled hydrocarbons. Marine geochemical surveys provide a tantalizing clue that hydrocarbons have been generated and are still present in these sediments. Sediment and water column "sniffer" geochemical surveys were undertaken in the Bay of Fundy and parts of Chignecto Bay on behalf of Amoco Canada (InterOcean Systems, Inc., 1987). Although not conclusive, as all anomalies are quite low when compared against a very low background, these surveys revealed two trends of anomalies. The first is in the western end of the Fundy Subbasin and southward towards the Gulf of Maine and consists of small quantities of methane and ethane with a positive wetness trend characteristic of petroleum sources. This trend corresponds to a part of the basin where post-depositional faulting has broken the strata, with some faults extending close to the sea floor. The second trend corresponds exactly with the up-dip (southern) subcrop edge of the Scots Bay Formation and consists of small quantities of methane and higher hydrocarbons with the general characteristics of dry gas (Fig. 24). Although the anomalies are very small, the fact that they correlate well with mapped geological features which would provide migration pathways is deemed more than coincidental. It suggests that hydrocarbons have indeed been generated in Fundy Basin and are diffusing laterally and vertically through the sediments and are "micro-seeping" into the Holocene sediments and overlying water column. Also, the weak nature of the anomalies may be interpreted as an indication of trap seal integrity. The source rocks generating these hydrocarbons would not be restricted to the Scots Bay Formation but, due to the nature of the late tectonics, may include the underlying Blomidon and even Wolfville formations.

Therefore, although the source rock facies have yet to be sampled, basin filling models, seismic facies analysis, and indirect geochemical indicators suggest that they exist in Fundy Basin. Furthermore, it appears that hydrocarbons may be slowly diffusing to the surface and/or migrating laterally within the strata. The sediments most likely to contain organic matter and hence have a source rock potential in the Fundy Subbasin are those of the Scots Bay Forma- 
tion, followed by those of the Blomidon Formation and then the Wolfville Formation. Within Chignecto Subbasin, the better potential occurs in the Scots Bay and Blomidon formations. In addition, speculative lacustrine strata in the Wolfville Formation may also have hydrocarbon source potential.

\section{Reservoirs}

Reservoir beds are expected to be common throughout Fundy Basin, although their quality and quantity will vary with formation and depositional environment. Based on outcrops, reservoir quality beds can occur in fluvial sandstones in all three formations and in eolian sandstones mainly in the Wolfville and Scots Bay/McCoy Brook formations. The differences in depositional facies are also reflected in their preserved reservoir characteristics of porosity and permeability.

The best potential reservoirs are eolian sandstones. Outcrops of eolian facies are found in all but the Grand Manan Subbasin. They are most common along the border fault side of the basin, the result of prevailing northeasterly winds blowing along the strike of the basin and reworking exposed lacustrine and alluvial sediment (Hubert and Mertz, 1980, 1984). Their extent toward the axial regions of the basin is unknown but probably fluctuated with lake level and regional changes in aridity.

In Minas Subbasin, the Wolfville eolian sandstones are located at the top of the formation and are best exposed along a $3 \mathrm{~km}$ coastal cliff section at Economy Mountain (Fig. 19). The sandstones are about $40 \mathrm{~m}$ thick and exhibit good to excellent visible porosity. Younger McCoy Brook formation eolian sandstones also have excellent reservoir characteristics, although their lateral extent may be erratic due to their deposition within small micrograbens formed along the flank of the Cobequid Fault System.

Within the Fundy and Chignecto subbasins, Wolfvilleequivalent eolian strata, like those found at Martin Head and Split Rock, New Brunswick, would also be considered as potential reservoirs. Eolian and fluvial sandstones which onlap the truncated Carboniferous succession beneath Chignecto Subbasin could act as reservoirs for coal derived hydrocarbons that have migrated up from deeper sources.

In the subsurface, Chinampas N-37 encountered generally pebbly, medium-grained, subrounded and moderately to well sorted fluvial sandstones with variable amounts of calcite and silica cements. A cumulative thickness of $280 \mathrm{~m}$ of reservoir sands with porosities ranging from 3 to $16 \%$ were recorded in this well. The Cape Spencer No. 1 well contained less reservoir sand (cumulative $100 \mathrm{~m}$ ), although the average porosities were $20 \%$ or more (Chevron Canada Resources, Ltd., 1984). The Wolfville Formation in N-37 was drillstem tested and yielded a pipe recovery of $1228 \mathrm{~m}$ of saline water $\left(125,000 \mathrm{ppm} \mathrm{Cl}^{-}\right)$(Mobil Oil Canada, Ltd., 1975).

\section{Traps and seals}

The Fundy Basin seismic data reveal evidence for two tectonic episodes. The earliest event represents the major phase of early Mesozoic extension associated with basin formation. This continued sporadically through the Mid Jurassic and resulted in most of the structural features seen today. As described above, this was overprinted by a transpressional event, possibly during the Mid Jurassic, which resulted in structural inversion and complex flower structures along the westward extension of the Cobequid Fault and a series of large anticlinal and synclinal structures along the Headlands Fault System. The only regional seismic horizon suitable for mapping structure is the North Mountain Basalt (Fig. 15). The Jurassic extensional tectonism formed a variety of synsedimentary structures. Large reverse-drag or rollover anticlines, sometimes fault-bounded, are the most common structural type (Figs. 5, 12). These are associated with down-to-the-basin movement of the Mesozoic strata and are found mainly on the northern and western sides of the basin.

The projection of a final dextral transpressional motion along the Cobequid/Chedabucto Fault and inversion of the Headlands Fault System is revealed by its structural expression in Triassic-Jurassic strata. Both positive- and negativeflower structures (Harding, 1985) are indicated from the seismic data at convergent (compressional/locking) and divergent (extensional/releasing) bends of the fault as it crosses the mouth of Chignecto Bay to link with the Headlands Fault System. At convergent bends, minor thrusting of the Mesozoic sediments occurs adjacent to the fault. The subsequent reversal of motion on the normal faults of the Headlands system enlarged the anticlinal closures, many of which were initiated as rollover anticlines, sometimes moving the apex of closure in the hanging wall block higher than the formation in the foot wall block. Syntectonic deposition of clastic sediments into the syncline adjacent to one of these structures is highlighted in Figure 22.

Most of the structures which have been recognized in the Fundy Subbasin are related to faulting. Rollover into listric normal faults form a number of structures developed during deposition of the Scots Bay Formation. These earlyformed traps were in place at the time of maturation of Blomidon and lower Scots Bay organic facies. Even the final movement on the compressional structures, such as those drilled at the Chinampas and Cape Spencer, was complete before the effected rocks were fully mature although they may have resulted in some relocation or loss of early migrated hydrocarbons.

Possibilities for unconformity and facies-type stratigraphic traps are recognized mainly in Chignecto Subbasin where known gas-prone Carboniferous sediments are overlain by late Triassic-early Jurassic lacustrine, playa and fluvial sediments (Figs. 12, 25) or at base of the North Mountain Basalt, which overlies a series of source rock and reservoir possibilities in the Blomidon Formation.

\section{Burial history}

Some of the source rock facies of the Newark Supergroup failed to reach thermal maturity due to early uplift and partial erosion, whereas others are fully mature to overmature, either through deep burial or igneous intrusion 
into the sedimentary pile (Pratt and Burruss, 1988; Pratt et al., 1988; Pratt, 1989; Kruge et al., 1990). Based on geothermal gradients of 2.24 and $2.44^{\circ} \mathrm{C} / 100 \mathrm{~m}$ for the Cape Spencer and Chinampas wells, respectively, there is little doubt that the Wolfville and Blomidon formations are thermally mature anywhere that they occur below a present depth of $3 \mathrm{~km}$. This would coincide roughly with the area enclosed by the $3 \mathrm{~km}$ isopach on Figure 8. Maturation within the Scots Bay Formation is more problematic since that formation had a maximum depth of burial of about $4.5 \mathrm{~km}$ and, at current geothermal conditions, reached a maximum temperature of about $115^{\circ} \mathrm{C}$.

Palynomorphs recovered from Chinampas N-37 indicate that all the sediments penetrated by this well have Thermal Alteration Index (TAI) ranges from 2.50 at water bottom to 3.25 at a total depth of $3662 \mathrm{~m}$ (Mobil Oil Canada, Ltd., unpublished report, 1975). Data from the Cape Spencer well, although tenuous, gives a TAI range of 2.50 at water bottom to 2.75 at $2405 \mathrm{~m}$ (Chevron Canada Resources, Ltd., unpublished report, 1986). Volcanism does not appear to have had a regional effect on the maturation history of the sediments. The data suggest that sediments within the Fundy Subbasin (down to at least $3600 \mathrm{~m}$ ) are within the oil-generating window. Sediments below this depth are inferred to be within the oil-cracking and then dry gas windows. However, the presence of a greater thickness of younger sediments, long since removed, could have pushed the sediments deeper into the dry gas zone.

Using the amount of truncation at the seafloor, we have calculated that up to $2 \mathrm{~km}$ of Scots Bay strata have been removed from the basin over the last $\sim 175 \mathrm{Ma}$, making the maximum thickness of post North Mountain Basalt sediments about $4.5 \mathrm{~km}$. This extra 1.5 to $2 \mathrm{~km}$ of cover would have moved the thicker accumulations of Scots Bay Formation into the fully mature window prior to erosion. Preliminary results from apatite fission-track analysis of several early Mesozoic samples from the Chignecto Bay and Bay of Fundy areas tend to support this interpretation (M. Zentilli, personal communication, 1995).

With these data, simple burial history curves were constructed using the BasinMod BRIDGE ${ }^{\mathrm{TM}} 1 \mathrm{D}$ modular basin modelling system (Platte River Associates, Inc., 1992) for dummy well locations, selected by seismic, in both the Chignecto and Fundy subbasins. These locations were selected using the assumption that the deepest water lacustrine facies and any organic material would be preserved in the deepest parts of the basins. At both locations, an additional $2000 \mathrm{~m}$ of sediment was added to the section. This is the maximum amount of strata which we believe could have existed prior to erosion although, in places, it may have been considerably thinner.

Using a Type 1 lacustrine algal source rock, the burial curve for Fundy Subbasin (Fig. 26) reveals that the sediments in all formations except for the upper half of the Scots Bay Formation are overmature. Due to rapid burial and thickness of section, hydrocarbon generation from Type 1 kerogen would occur in a geologically short period of time with both oil and gas being generated. Following erosion, the stratigraphic interval with peak oil generation would be near seafloor in the depocentre. In Chignecto Subbasin (Fig. 27), the thinner stratigraphic section results in the lower half of the Scots Bay Formation being the best candidate to generate hydrocarbons.

Varying the kerogen type and kinetics to reflect a mix of organic matter, including some terrestrial plant material, would probably result in a significantly broader oil window and the extension of the prospective zone downward into the Blomidon Formation (P.K. Mukhopadhyay, personal communication, 1995). The reader is cautioned that these models are very preliminary and with planned additional geochemical and geochronological studies the authors expect to better quantify the model data and refine the resultant burial history curves.

In summary, abundant reservoir rock, numerous types of structures and traps, and a thermally mature stratigraphic sequence are all present within Fundy Basin. Although source rock quality and quantity has yet to be confirmed, it is inferred to exist within the two major subbasins. A study of apatite fission tracks from early Mesozoic sediments would probably resolve the question of how much of the stratigraphic section has been removed by erosion, and provide additional constraints on the burial history of the basin. Of the two wells drilled, neither can be considered to have adequately tested the basin's hydrocarbon potential. Chinampas was drilled on the flank of the structure and thus failed to evaluate it and Cape Spencer drilled a proximal alluvial fan complex far from the source rock facies. Other possible reasons for the lack of shows in these two wells would include the lateness of the structures, the distance from source areas and the number of intervening normal faults which may have obstructed or deflected migrating hydrocarbons.

Therefore, although lacking only unequivocal confirmation of a hydrocarbon source, when compared with other east coast rift basins, Fundy Basin appears to have the necessary components required to generate, migrate and trap hydrocarbons.

\section{ACKNOWLedgements}

This regional geological synthesis of the Bay of Fundy region is the culmination of many years of separate and then joint research by the two senior authors. As a result, we had the unique advantage of being able to draw upon the insights and findings of many workers specializing in many aspects of Appalachian, Carboniferous and Newark Supergroup strata in eastern North America.

We acknowledge Paul Olsen and his students for their tremendous contributions to the current understanding of the early Mesozoic rift basins of eastern North America and we extend sincere thanks for his enthusiastic support and willingness to discuss all aspects of his research. Similarly, Martha Withjack is acknowledged for enlightening discussions on the tectonic evolution of Fundy Basin both from outcrop and seismic data.

We extend our sincere thanks to early workers on the subsurface of the basin for discussion and support: Don Axford, 


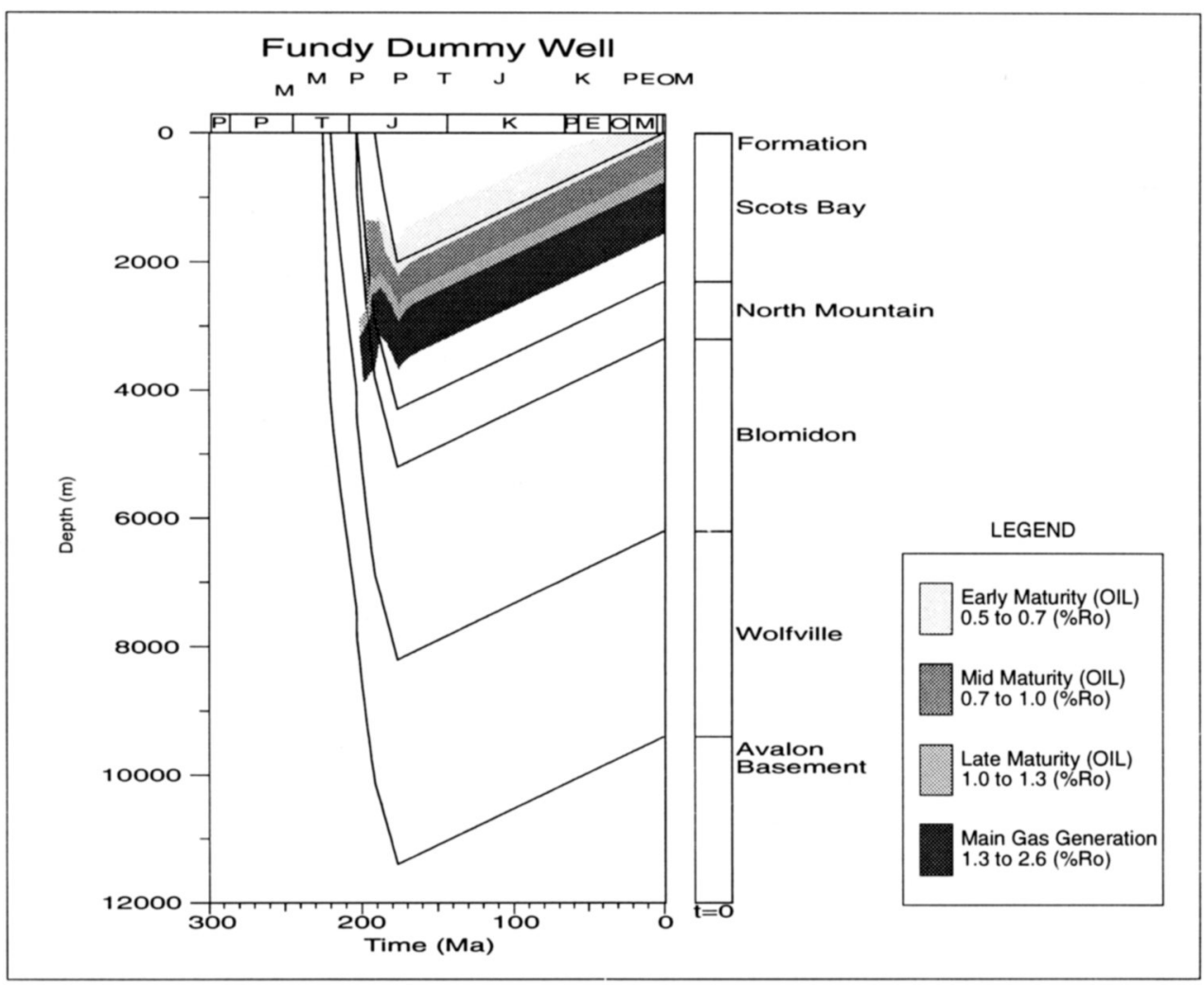

Fig. 26. Burial history curves for a dummy well in Fundy Subbasin. Data include $2000 \mathrm{~m}$ of Scots Bay Formation which has subsequently been eroded.

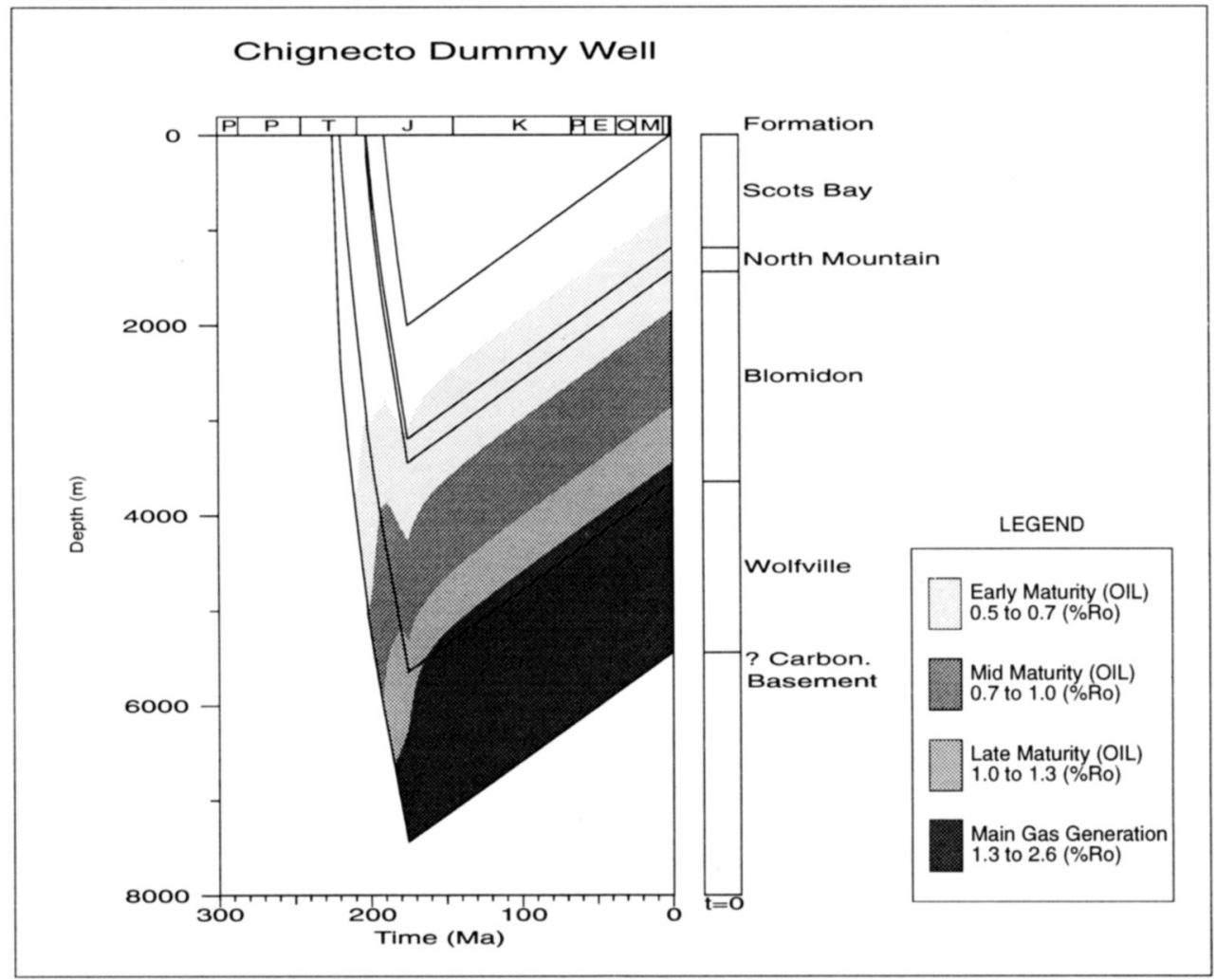

Fig. 27. Burial history curves for a dummy well in Chignecto Subbasin. Data include $2000 \mathrm{~m}$ of Scots Bay Formation which has subsequently been eroded. 
Don Magnusson, Ken Drummond and Greg Nadon. Tony Tankard is acknowledged for his critical review of an earlier version of this paper.

The authors give special thanks to Bill MacMillan and Bob Grantham for assistance in the field and to Bernie Crilley for patient attempts to extract palynomorphs from less than optimum samples. Joe Smoot and Warren Manspeizer are acknowledged for their stimulating discussions on Newark Supergroup stratigraphy and sedimentology. Discussions and guidance in modelling the thermal history of the basin was provided by Mark Williamson and his co-workers at GSC Atlantic, and Prasanta Mukhopadhyay is thanked for vitrinite reflectance analyses and discussions on hydrocarbon source rocks in lacustrine basins. Peter Stringer provided the authors with numerous references and copies of his field notes on many of the New Brunswick sections. We enjoyed fruitful discussions with Bob Boehner, Bob Ryan and Al Grant on late Paleozoic basin architecture and stratigraphy in the Maritimes and thank them for their patience in discussing our numerous questions. Finally, we wish to thank the reviewers of this paper for many helpful comments and suggestions and the Geological Survey of Canada and the CanadaNova Scotia Offshore Petroleum Board for permission to publish this research. This is Geological Survey of Canada Contribution No. 42895.

ACkermann, R.V. and Schlische, R.W. 1993. Triassic buried interstratal karst, Fundy Basin, Canada. Geological Society of America, Abstract with Programs, 25(6), p. A-69.

Alcock, F.J. 1948. Grand Manan, New Brunswick. Geological Survey of Canada, Map 965A, with descriptive notes.

Aumento, F. 1966. Zeolite minerals, Nova Scotia. In Geology of parts of the Atlantic Provinces. Edited by W.J. Poole. Geological Association of Canada, pp. 71-94.

BAIRD, D. and OLSEN, P.E. 1983. Late Triassic herpetofauna from the Wolfville Formation of the Minas Basin (Fundy Basin), Nova Scotia, Canada. Geological Society of America Annual Meeting, Abstract with Programs, 15, p. 11.

BARR, S.M. and RAESIDE, R.P. 1989. Tectono-stratigraphic terranes in Cape Breton Island, Nova Scotia: Implications for the configuration of the northern Appalachian orogen. Geology, 17 , pp. $822-825$.

Barss, M.S., Buink, J.P., and Williams, G.L. 1979. Palynological zonation and correlation of sixty-seven wells, eastern Canada. Geological Survey of Canada, Paper 78-24, 118 p.

BeLt, E.S. 1968. Post-Acadian rifts and related facies, Eastern Canada. In Studies of Applachian geology, northern and Maritime. Edited by E-an Zen, W.S. White, J.B. Hadley and J.B. Thompson, Jr. Interscience, New York, pp. 95-113.

Birney, C.C. 1985. Sedimentology and petrology of the Scots Bay Formation (Lower Jurassic), Nova Scotia, Canada. Unpublished Master of Geology thesis, University of Massachusetts, Amherst, Massachusetts, 324 p.

BirneY-DE Wet, C.C. and Hubert, J.F. 1989. The Scots Bay formation, Nova Scotia, Canada: a Jurassic carbonate lake with silica-rich hydrothermal springs. Sedimentology, 36, pp. 857 873.

Boner, F.J., Graves, R.M., and Finck, P.W. 1989. Preliminary till geochemistry and till clast geology of the Windsor map sheet (21A/16), South Mountain Batholith Project. Scale $1: 50,000$. OFM 88-052.
Bowman, H.E., Sheppard, R.C., and Zieglar, D.G. 1987. The Early Mesozoic rift system: hydrocarbon frontier on the east coast. Oil and Gas Journal, 85(41), pp. 57-58, 63.

BRown, D.E. 1986. The Bay of Fundy: thin-skinned tectonics and resultant early Mesozoic sedimentation. Basins of Eastern Canada and Worldwide Analogues, Atlantic Geoscience Society, Halifax, Nova Scotia, Program with Abstracts, p. 28.

Brown, D.E. and Grantham, R.G. 1992. Fundy Basin rift tectonics and sedimentation. Field Excursion A-3 Guidebook, Geological Association of Canada/Mineralogical Association of Canada Joint Annual Meeting, Wolfville, Nova Scotia, p. 57.

Chevron Canada Resources, Ltd. 1984. Irving-Chevron et al. Cape Spencer No. 1 Well History Report. Canada-Nova Scotia Offshore Petroleum Board, Halifax, Nova Scotia, 47 p. with enclosures.

CofLIN, K.C. In press. MDA seismic reflection profile of the Meguma Group, Renfrew, Nova Scotia. Geological Survey of Canada, Open File.

Colwell, J.A. 1980. Zeolites in the North Mountain Basalt, Nova Scotia. Field Trip Guidebook 18, Joint Annual Meeting of the Geological Association of Canada and Mineralogical Association of Canada, Wolfville, Nova Scotia, 16 p.

Darton, N.H. 1889. On the great lava flows and intrusive trap sheets of the Newark System in New Jersey. American Journal of Science, 38, pp. 134-139.

Dawson, J.W., Sir. 1855. Acadian Geology. Oliver and Boyd, Edinburgh, 388 p.

Donohoz, H.V., JR. and Wallace, P.I. 1978. Geology Map of the Cobequid Highlands. Nova Scotia Department of Mines, Preliminary Map 78-1.

---- 1982. Geological map of the Cobequid Highlands (Colchester, Cumberland and Pictou counties), Nova Scotia. Nova Scotia Department of Mines and Energy. Map sheets 82-6, 82-7, 82-8, 82-9 and Legend.

Elsevier Science Publishing Company. 1987. Geologic Time Table - Fourth Edition. Compiled by B.U. Haq and F.W.B. Ban Eysinga. Elsevier, Amsterdam.

Finck, P.W., Graves, R.M., and Boner, F.J. 1989. Preliminary glacial and till clast geology of the New Germany map sheet $(21 \mathrm{~A} / 10)$, South Mountain Batholith Project. Scale 1:50,000. OFM 89-019.

Finck; P.W., Graves, R.M., Boner, F.J., and Bent, H.B. 1990. Preliminary glacial and till clast geology of Gaspereau Lake, 21A/15, South Mountain Batholith Project. Scale 1:50,000. OFM 90-014.

Fowell, S.J. and Traverse, A. 1995. Palynology and age of the upper Blomidon Formation, Fundy Basin, Nova Scotia. Review of Palaeobotany and Palynology, 86, pp. 211-233.

Gibling, M.R., Calder, J.H., Ryan, R., van de Poll, H.W., and Yeo, G.M. 1992. Late Carboniferous and Early Permian drainage patterns in Atlantic Canada. Canadian Journal of Earth Sciences, 29, pp. 338-352.

Gradstein, F.M., Agterberg, F.P., Ogg, J.G., Hardenbol, J., van Veen, P., Thierry, J., and Hunng, Z. 1994. A Mesozoic time scale. Journal of Geophysical Research, 99, No. B12, pp. 24,051-24,074.

GratACAP, L.P. 1886. Fish remains and tracks in the Triassic rocks of Weehawken, New Jersey. American Naturalist, 20, pp. 243-246.

HaQ, B.U., HARdenbol, J., and VAll, P.R. 1988. Mesozoic and Cenozoic chronostratigraphy and cycles of sea level change. In Sea-Level Changes - An Integrated Approach. Special Publication, Society of Economic Paleontologists and Mineralogists, 42, pp. 71-108. 
Harding, T.P. 1985. Seismic characteristics and identification of negative flower structures, positive flower structures, and positive structural inversion. American Association of Petroleum Geologists Bulletin, 69, pp. 582-600.

Harland, W.B., Armstrong, R.L., Cox, A.V., Craig, L.E., Smith, A.G., and SMITH, D.G. 1990. A geologic time scale 1989. Cambridge University Press, New York, 265 p.

HaY, W.W., Behensky, J.F., JR., Barron, E.J., and Sloan, J.L., II. 1982. Late Triassic-Liassic paleoclimatology of the protocentral North Atlantic rift system. Palacogeography, Palaeoclimatology, Palaeoecology, 40, pp. 13-30.

Hayatsu, A. 1979. K-Ar isochron age of the North Mountain Basalt, Nova Scotia. Canadian Journal of Earth Sciences, 16, pp. 973-975.

Hiтснсоск, E. 1823. A sketch of the geology, mineralogy, and scenery of the regions contiguous to the River Connecticut; with a geological map and drawings of organic remains; and occasional botanical notices. American Journal of Science, 6, pp. 201-236.

Hodych, J.P. and Dunning, G.R. 1992. Did the Manicouagan impact trigger end-of-Triassic mass extinction? Geology, 20, pp. 51-54.

Howie, R.D. and Barss, M.S. 1975. Upper Paleozoic rocks of the Atlantic Provinces, Gulf of St. Lawrence and adjacent continental shelf. In Offshore geology of Eastern Canada. Edited by W.J.M. van der Linden and J.A. Wade. Geological Survey of Canada, Paper 74-30, pp. 35-50.

HUBert, J.F. and ForLenza, M.F. 1988. Sedimentology of braidedriver deposits in Upper Triassic Wolfville redbeds, southern shore of Cobequid Bay, Nova Scotia, Canada. In Triassic-Jurassic Rifting: Continental Breakup and the Origin of the Atlantic Ocean and Passive Margins. Edited by W. Manspeizer. Elsevier, Amsterdam, The Netherlands, pp. 231-247.

HuBert, J.F. and Hyde, M.G. 1982. Sheet-flow deposits of graded beds and mudstones on an alluvial sandflat-playa system: Upper Triassic Blomidon redbeds, St. Mary's Bay, Nova Scotia. Sedimentology, 29, pp. 457-474.

Hubert, J.F. and Mertz, K.A. 1980. Eolian dune field of Late Triassic age, Fundy Basin, Nova Scotia. Geology, 8, pp. 516519.

-..- 1984. Eolian sandstones in Upper Triassic -Lower Jurassic red beds of the Fundy basin, Nova Scotia. Journal of Sedimentary Petrology, 54, pp. 798-810.

Interocean Systems, Inc., San Diego, California. 1987. Eastern Canada geochemical survey, data description and interpretation report. Prepared for AMOCO Canada Production Company. Released in 1992 by the Canada-Nova Scotia Offshore Petroleum Board.

JANSA, L.F. and WADE, J.A. 1975a. Geology of the continental margin off Nova Scotia and Newfoundland. In Offshore geology of eastern Canada. Edited by W.J.M. van der Linden and J.A. Wade. Geological Survey of Canada, Paper 74-30, 2, pp. 51-106.

-.-- 1975b. Paleogeography and sedimentation in the Mesozoic and Cenozoic, southeastern Canada. In Canada's Continental Margins and Offshore Petroleum Exploration. C.J. Yorath. Edited by E.R. Parker and D.J. Glass. Canadian Society of Petroleum Geologists, Memoir 4, pp. 79-102.

JoNG, W. 1985. The subsurface lithostratigraphy of the Triassic Blomidon and Upper Wolfville formations (Fundy Basin) of the central Annapolis Valley, Nova Scotia. Thesis, Acadia University, Wolfville, Nova Scotia, 142 p.

Katz, B.J., Robison, C.R., Jorjorian, T., and Foley, F.D. 1988. The level of organic maturity within the Newark Basin and its associated implications. In Triassic-Jurassic Rifting:
Continental Breakup and the Origin of the Atlantic Ocean and Passive Margins. Edited by W. Manspeizer. Elsevier, Amsterdam, The Netherlands, pp. 683-696.

Keen, C.E., Loncarevic, B.D., Reid, I., Woodside, J., Haworth, R.T., and WILLiams, H. 1990. Tectonic and geophysical overview. In Geology of the continental margin of eastern Canada. Edited by M.J. Keen and G.L. Williams. Geological Survey of Canada, Geology of Canada No. 2, pp. 31-85 (also Geological Society of America, The Geology of North America, I-1).

Keen, C.E., KaY, W.A., KePPIE, D., Marillier, F., Pe-Piper, G., and WALDRON, J.W. 1991. Deep seismic reflection data from the Bay of Fundy and Gulf of Maine: tectonic implications for the northern Appalachians. Canadian Journal of Earth Sciences, 28(7), pp. 1096-1111.

KePpIE, J.D. 1977. Tectonics of southern Nova Scotia. Nova Scotia Department of Mines, Paper 77-1, 34 p.

.... 1979. Geological Map of the Province of Nova Scotia. Nova Scotia Department of Mines, Scale 1:500,000.

.... 1982. The Minas Geofracture. In Major Structural Zones and Faults of the Northern Appalachians. Edited by P. St. Julien and J. Beland. Geological Association of Canada, Special Paper, 24, pp. 263-280.

.... 1989. Northern Appalachian terranes and their accretionary history. Geological Society of America, Special Paper, 230.

-.-. 1992. From whence came the Meguma Terrane? Geological Association of Canada/Mineralogical Association of Canada Joint Annual Meeting, Wolfville, Nova Scotia, Abstracts with Program, 17, p. A56.

Keppie, J.D. and Muecke, G.K. 1979. Metamorphic Map of Nova Scotia. Nova Scotia Department of Mines and Energy. Scale $1: 1,000,000$.

KLEIN, G. DE V. 1954. The geology of the Acadian Triassic in the type areas, northeastern Annapolis-Cornwallis Valley, Kings County, Nova Scotia. Unpublished M.Sc. thesis, University of Kansas, Lawrence, Kansas, 143 p.

...- 1962. Triassic sedimentation, Maritime Provinces, Canada. Geological Society of America Bulletin, 73, pp. 1127-1146.

-.-- 1963a. Boulder surface markings in Quaco Formation (Upper Triassic), St. Martin's, New Brunswick, Canada. Journal of Sedimentary Petrology, 33(1), pp. 49-52, figures 1-2.

..--1963b. Regional implications of Triassic paleocurrents, Maritime Provinces, Canada. Journal of Geology, 71, pp. 801-808.

Kruge, M.A., Hubert, J.F., Akes, R.J., and Meriney, P.E. 1990. Biological markers in Lower Jurassic synrift lacustrine black shales, Hartford basin, Connecticut, U.S.A. Organic Geochemistry, 15(3), pp. 281-289.

Kruge, M.A., Hubert, J.F., Bensley, D.F., Crelling, J.C., Akes, R.J., and MerineY, P.E. 1990. Organic geochemistry of a Lower Jurassic synrift lacustrine sequence, Hartford Basin, Connecticut, U.S.A. Organic Geochemistry, 16, pp. 689-701.

MacDonald, M.A. and Horne, R.J. 1988. Petrology of the zoned, peraluminous Halifax Pluton, south-central Nova Scotia. Maritime Sediments and Atlantic Geology, 24, pp. 33-45.

MacDonald, M.A., Horne, R.J., Corey, M.C., and HaM, L.J. 1992. An overview of recent bedrock mapping and follow-up petrological studies of the South Mountain Batholith, southwestern Nova Scotia, Canada. Atlantic Geology, 28, pp. 7 28.

MACLURE, W. 1817. Observations on the geology of the United States of America. Abraham Small, Philadelphia, 127 p.

MacNaughton, R.B. 1990. Invertebrate ichnology of the Triassic of the Point Lepreau and St. Martins regions, southern New Brunswick. Unpublished Honours B.Sc. thesis, University of New Brunswick, 108 p. 
Magnusson, D.H. 1955. The Triassic sedimentary rocks at St. Martins, New Brunswick. Unpublished M.Sc. thesis, University of New Brunswick, 194 p.

Manspeizer, W. 1980. Rift tectonics inferred from volcanic and clastic structure. In Field Studies of New Jersey Geology and Field Trips. Edited by W. Manspeizer. New York State Geological Association, pp. 314-350.

.-.- 1981. Early Mesozoic basins of the central Atlantic passive margins. In Geology of passive continental margins. Edited by A.W. Bally. American Association of Petroleum Geologists, Education Course Notes, 19, pp. 1-60.

-..- 1982. Triassic-Liassic basins and climate of the Atlantic passive margins. Geol. Rundsch. 73, pp. 895-917.

...- 1988. Triassic-Jurassic rifting and opening of the Atlantic: an overview. In Triassic-Jurassic Rifting: Continental Breakup and the Origin of the Atlantic Ocean and Passive Margins. Edited by W. Manspeizer. Elsevier, Amsterdam, The Netherlands, pp. 249-274.

Manspeizer, W. and Olsen, P.E. 1981. Rift basins of the passive margin: tectonics, organic-rich lacustrine sediments, basin analysis. In Field Guide to the Geology of the Paleozoic, Mesozoic, and Tertiary rocks of New Jersey and the Central Hudson Valley. Edited by J.G.W. Hobbs, III. Petroleum Exploration Society of New York, New York, New York, pp. 25-105.

Margolis, J., Robinson, G.R., JR., and Schafer, C.M. 1986. Annotated bibliography of studies on the geology, geochemistry, mineral resources and geophysical character of the eastern United States, 1880-1984. U.S. Geological Survey, Bulletin $1688,492 \mathrm{p}$.

MARTEL, A.T., MCGregor, D.C., and UtTING, J. 1993. Stratigraphic significance of Upper Devonian and Lower Carboniferous miospores from the type area of the Horton Group, Nova Scotia. Canadian Journal of Earth Sciences, 30, pp. 10911098.

MAWER, C.K. and White, J.C. 1987. Sense of displacement on the Cobequid-Chedabucto fault system, Nova Scotia, Canada. Canadian Journal of Earth Sciences, 24, pp. 217-223.

McCutcheon, S.R. and RoBnson, P.T. 1987. Geological constraints on the genesis of the Maritimes Basin, Atlantic Canada. Canadian Society of Petroleum Geologists, Memoir 12, pp. 287-297.

Mertz, K.A. and Hubert, J.F. 1990. Cycles of sand-flat sandstone and playa-mudstone in the Triassic-Jurassic Blomidon redbeds, Fundy rift basin, Nova Scotia: implications for tectonic and climatic controls. Canadian Journal of Earth Sciences, 27 , pp. $442-451$.

Mobil Oil Canada, LtD. 1975. Mobil-Gulf Chinampas N-37. Well History Report, Canada-Nova Scotia Offshore Petroleum Board, Halifax, Nova Scotia, 63 p. with enclosures.

NADON, G.C. 1981. The stratigraphy and sedimentology of the Triassic at St. Martins and Lepreau, New Brunswick. M.Sc. thesis, McMaster University, 279 p.

Nadon, G.C. and Middleton, G.V. 1984. Tectonic control of Triassic sedimentation in southern New Brunswick: local and regional implications. Geology, 12, pp. 619-622.

-.-- 1985. The stratigraphy and sedimentology of the Fundy Group (Triassic) of the St. Martins area, New Brunswick. Canadian Journal of Earth Sciences, 22, pp. 1183-1203.

NANCE, R.D. 1986. Late Carboniferous tectonostratigraphy in the Avalon Terrane of southern New Brunswick. Maritime Sediments and Atlantic Geology, 22, pp. 308-326.

-.-. 1987. Dextral transpression and late Carboniferous sedimentation in the Fundy Coastal Zone of southern New Brunswick. In Sedimentary Basins and Basin-Forming Mechanisms. Edited by C. Beaumont and A.J. Tankard. Canadian Society of Petroleum Geologists, Memoir 12, pp. 363-377.

Olsen, P.E. 1981. Comment on "Eolian dune field of Late Triassic age, Fundy Basin, Nova Scotia". Geology, pp. 557-559.

-.-- 1985. Distribution of organic-rich rocks in the early Mesozoic Newark Supergroup. In Proceedings of the Second U.S. Geological Survey Workshop on the Early Mesozoic Basins of the Eastern United States. Edited by G.R. Robinson Jr. and A.J. Froelich. U.S. Geological Survey, Circular 946, pp. 61-64.

-.-. 1986. A 40-million-year lake record of early Mesozoic orbital climatic forcing. Science, 234, pp. 842-848.

-... 1988a. Paleontology and paleoecology of the Newark Supergroup (early Mesozoic, eastern North America). In Triassic-Jurassic Rifting: Continental Breakup and the Origin of the Atlantic Ocean and Passive Margins. Edited by W. Manspeizer. Elsevier, Amsterdam, The Netherlands, pp. 185230.

-.-. 1988b. Continuity of strata in the Newark and Hartford Basins of the Newark Supergroup. USGS Bulletin 1776, pp. 6-18.

-.-. 1990. Tectonic, Climatic, and Biotic Modulation of Lacustrine Ecosystems-Examples from Newark Supergroup of Eastern North America. In Lacustrine Basin Exploration-Case Studies and Modern Analogs. Edited by B.J. Katz. American Association of Petroleum Geologists, Memoir 50, pp. 209-224.

...- 1993. The incipient breakup of Pangea: the Newark Rift Basins. Carboniferous to Jurassic Pangea, Program and Abstracts, Annual Convention of the Canadian Society of Petroleum Geologists, Calgary, Alberta, p. 230.

Olsen, P.E. and Fedosh, M.S. 1988. Duration of the early Mesozoic extrusive igneous episode in eastern North America determined by use of Milankovitch-type lake cycles. Geological Society of America, Abstracts with Programs, 20, p. 59.

Olsen, P.E. and Kent, D.V. 1992. Field trip to the south central Newark Basin for the 7 th international workshop on fission track thermochronology.

Olsen, P.E. and Sugs, H.-D. 1986. Correlation of continental Late Triassic and Early Jurassic sediments, and patterns of the Triassic-Jurassic tetrapod transition. In The Beginning of the Age of Dinisaurs: faunal changes across the TriassicJurassic Boundary. Edited by K. Padian. Cambridge University Press, Cambridge, England, pp. 321-351.

Olsen, P.E. and Withuack, M.O. 1994. Inversion During the Early Stages of Seafloor Spreading: seismic and field evidence from the Bay of Fundy, Canada. American Association of Petroleum Geologists Annual Convention, Denver, Colorado, Program with Abstracts, p. 228.

Olsen, P.E., Schlische, R.W., and Gore, P.J.W. (Editors) 1989. Tectonic, Depositional and Paleoecological History of the Early Mesozoic Rift Basins, Eastern North America. American Geophysical Union, Washington, Field Trip Guidebook T351,174 p.

PALMer, A.R. 1983. The decade of North American geology, 1983 geologic time scale. Geological Society of America.

PAPEZIK, V.S. and BARR, S.M. 1981. The Shelburne dike, an early Mesozoic diabase dike in Nova Scotia: Mineralogy, chemistry and regional significance. Canadian Journal of Earth Sciences, 18, pp. 1346-1355.

Papezik, V.S., Greenough, J.D., Colwell, J.A., and Mallinson, T.J. 1988. North Mountain basalt from Digby, Nova Scotia: models for a fissure eruption from stratigraphy and petrochemistry. Canadian Journal of Earth Sciences, 25, pp. 7483. 
Perkins, R.E. 1981. Sedimentology of the Upper Triassic redbeds of Kings County, Nova Scotia. Unpublished M.Sc. thesis, University of Massachusetts, Amherst, Massachusetts, 196 p.

Petersen, T.A., Brown, L.D., Cook, F.A., Kaufman, S., and Oliver, J.E. 1984. Structure of the Riddleville Basin from COCORP seismic data and implications for reactivation tectonics. Jounal of Geology, 92, pp. 261-271.

Platte River Associates, Inc. 1992. BasinMod BRIDGE'M Modular Basin Modelling System, Version 1.0. Platte River Associates, Inc., Denver.

Plint, A.G. and van DE Poll, H.W. 1984. Structural and sedimentary history of the Quaco Head area, southern New Brunswick. Canadian Journal of Earth Sciences, 21, pp. 753-761.

Poole, W.H., SAnford, B.V., Williams, H., and Kelley, D.G. 1970. Geology of southeastern Canada. In Geology and Economic Minerals of Canada. Geological Survey of Canada, Economic Geology Report 1, pp. 227-304.

Powers, S. 1916. The Acadian Triassic. Journal of Geology, pp. 1-26, 105-122, 254-268.

Pratt, L.M. 1989. Deposition, diagenesis, and maturation of organic matter in rift-basin lacustrine shales of Triassic-Jurassic Newark Supergroup. American Association of Petroleum Geologists, Bulletin 73, p. 401.

Pratt, L.M. and Burruss, R.C. 1988. Evidence for petroleum generation and migration in the Hartford and Newark basins. In Studies of Early Mesozoic Basins of the Eastern United States. Edited by A.J. Froelich and G.R. Robinson. U.S. Geological Survey, Bulletin 1776, pp. 74-79.

Pratt, L.M., Shaw, C.A., and Burruss, R.C. 1988. Thermal histories of the Hartford and Newark basins inferred from maturation indicies of organic matter. In Studies of Early Mesozoic Basins of the Eastern United States. Edited by A.J. Froelich and G.R. Robinson. U.S. Geological Survey, Bulletin 1776, pp. 58-63.

Puffer, J.H. 1992. Eastern North American flood basalts in the context of the incipient preakup of Pangea. In Eastern North American Mesozoic Magmatism. Edited by J.H. Puffer and P.C. Ragland. Geological Society of America, Special Paper 268, pp. 95-118.

RAst, N. 1983. The northern Appalachian traverses in the Maritimes of Canada. In Profiles of orogenic belts. Edited by N. Rast and F.M. Delaney. American Geophysical Union-Geological Society of America, Geodynamics Series 10, pp. 243274.

Rast, N. and Grant, R. 1973. Transatlantic correlation of the Variscan-Appalachian orogeny. American Journal of Science, 373, pp. 572-579.

Rast, N., Kennedy, M.J., and Blackwood, R.F. 1976. Comparison of some tectonostratigraphic zones in the Applachians of Newfoundland and New Brunswick. Canadian Journal of Earth Sciences, 13, pp. 868-875.

Rast, N., Grant, R.H., PARKer, J.S.D., et al. 1978. The Carboniferous deformed rocks west of Saint John, New Brunswick. In Guidebook for field trips in southwestern Maine and southwestern New Brunswick. Edited by Allan Ludman. New England Intercollegiate Geological Conference, 70th Annual Meeting.

Ravenhurst, C., Donelick, R., Zentilli, M., et al. 1990. A fission track pilot study of the thermal effects of rifting on the onshore Nova Scotian margin, Canada. Nuclear Tracks and Radiation, Measurements, 17, pp. 373-378.

Reynolds, D.J. and Olsen, P.E. 1994. Seismic reflection character of lacustrine facies: implications for chronostratigraphic applications. Geological Society of America Annual Meet- ing, Seattle, Washington, Abstracts with Programs, 26(7), p. A-336.

Russell, I.C. 1878. The Newark System. American Geologist, 3 , p. 178.

-..- 1880. On the former extent of the Triassic Formation of the Atlantic states. American Naturalist, 14, pp. 703-712.

RYAN, R.J., BoEHNER, R.C., and CALDER, J.H. 1991. Lithostratigraphic revisions of the upper Carboniferous to lower Permian strata in the Cumberland Basin, Nova Scotia and the regional implications for the Maritimes Basin in Atlantic Canada. Bulletin of Canadian Petroleum Geology, 39(4), pp. 289-314.

Sarjeant, W.A.S. and Stringer, P. 1978. Triassic reptile tracks in the Lepreau Formation, southern New Brunswick, Canada. Canadian Journal of Earth Sciences, 15, pp. 594-602.

Schenk, P.E. 1991. Events and sea-level changes on Gondwana's margin: The Meguma Zone (Cambrian to Devonian) of Nova Scotia, Canada. Geological Society of America Bulletin, 103, pp. 512-521.

Schlische, R.W. 1990. Aspects of the structural and stratigraphic development of early Mesozoic rift basins of eastern North America. Unpublished Ph.D. thesis, Columbia University, New York.

---- 1991. Half-graben basin filling models: new constraints on continental extensional basin development. Basin Research, pp. 123-141.

-..- 1993. Anatomy and evolution of the Triassic-Jurassic continental rift system, eastern North America. Tectonics, 12(4), pp. 1026-1042.

Schlische, R.W. and OLsen, P.E. 1990. Quantitative filling model for continental extensional basins with applications to early Mesozoic rifts of eastern North America. Journal of Geology, 98, pp. 135-155.

Shin, K.G., Williams, H., and McNab, R. 1993. Gravity anomalies and major structural features of southeastern Canada and the Atlantic continental margin. Geological Survey of Canada, Map 1777A, scale 1:3,000,000.

Smitheringale, W.G. 1973. Geology of parts of Digby, Bridgetown and Gaspereau Lake map-areas, Nova Scotia. Geological Survey of Canada, Memoir 375, 78 p.

SMoot, J.P. 1991. Sedimentary facies and depositional environments of early Mesozoic Newark Supergroup basins, eastern North America. Palaeogeography, Palaeoclimatology, Palaeoecology, 84, pp. $369-423$.

-.-. 1993. Stratigraphic comparison of the evaporite-bearing early Mesozoic Fundy and Argana basins, Nova Scotia and Morocco. Carboniferous to Jurassic Pangea, Program and Abstracts, Annual Convention of the Canadian Society of Petroleum Geologists, Calgary, Alberta, p. 287.

SMOоT, J.P. and Olsen, P.E. 1988. Massive mudstones in basin analysis and paleoclimate interpretation of the Newark Supergroup. In Triassic-Jurassic Rifting: Continental Breakup and the Origin of the Atlantic Ocean and Passive Margins. Edited by W. Manspeizer. Elsevier, Amsterdam, The Netherlands, pp. 249-274.

Stevens, G.R. 1980. Mesozoic vulcanism and structure - northern Bay of Fundy region, Nova Scotia. Field Trip Guidebook 8, Joint Annual Meeting of the Geological Association of Canada and Mineralogical Association of Canada, Wolfville, Nova Scotia, 41 p.

StrINGer, P. and BURKe, K.B.S. 1985. Structure in southwest New Brunswick. Field Guide Excursion 9, Geological Association of Canada and Mineralogical Association of Canada, $34 \mathrm{p}$.

Stringer, P. and Pajari, G.E., Jr. 1981. Deformation of pre-Triassic rocks of Grand Manan, New Brunswick. In Current 
Research, Part C, Geological Survey of Canada, Paper 811C, pp. 9-15.

Swanson, M.T. 1986. Pre-existing fault control for Mesozoic basin formation in eastern North America. Geology, 14, pp. 419422.

SwiFT, D.J.P. and LYall, A.K. 1968. Reconnaissance of bedrock geology by sub-bottom profiler, Bay of Fundy. Geological Society of America, Bulletin 79, pp. 639-646.

Symons, D.T.A., Bormann, R.E., and JANS, R.P. 1989. Paleomagnetism of the Triassic red beds of the lower Fundy Group and Mesozoic tectonism of the Nova Scotia platform, Canada. Tectonophysics, 166, pp. 13-24.

TANNER, L.H. 1990. Sedimentology and diagenesis of the Lower Jurassic McCoy Brook Formation, Fundy Basin, Nova Scotia. Unpublished Ph.D. thesis, University of Massachusetts, Amherst, Massachusetts, 259 p.

....- 1993. Pedogenic features of the Triassic-Jurassic Fundy Group, Fundy Basin, Nova Scotia. Geological Society of America, Abstract with Programs, 25(6), p. A-69.

TAYLOR, G.K. and Resseter, R. 1985. Depostional and Structural Histories for the Richmond and Taylorsville Triassic Rift Basins. Abstract, American Association of Petroleum Geologists Eastern Section Meeting, Williamsburg, Virginia, American Association of Petroleum Geologists Bulletin, 69, pp. 1449-1450.

THомpson, J.P. 1974. Stratigraphy and geochemistry of the Scots Bay Formation, Nova Scotia. B.Sc. thesis, Acadia University, Wolfville, Nova Scotia, 261 p.

Traverse, A. 1983. Fundy Group palynoflorules on the northern margin of the Bay of Fundy, New Brunswick, Canada. Geological Society of America, Abstract with Programs, Northeastern Section, 15(3), p. 122.

---- 1987. Pollen and spores date origin of rift basins from Texas to Nova Scotia as early Late Triassic. Science, 236, pp. 1469. 1472.

VAN DER Voo, R. 1988. Triassic-Jurassic plate migrations and paleogeographic reconstructions in the Atlantic domain. In Triassic-Jurassic Rifting: Continental Breakup and the Origin of the Atlantic Ocean and Passive Margins. Edited by W. Manspeizer. Elsevier, Amsterdam, The Netherlands, pp. $29-40$.

van der Voo, R., Peinado, J., and Scotese, C.R. 1984. A paleomagnetic reevaluation of Pangea reconstructions. American Geophysical Union, Geodyn. Series, 12, pp. 11-26.

VAN Houten, F.B. 1964. Cyclic lacustrine sedimentation, Upper Triassic Lockatong Formation, central New Jersey and adjacent Pennsylvania. Kansas Geological Survey Bulletin, 169, pp. 497-531.
WADE, J.A. and JANSA, L.F. 1994. Preliminary interpretation of sub-North Mountain Basalt strata, Dark Harbour, Grand Manan Island, New Brunswick. In Current Research 1994-E. Geological Survey of Canada, pp. 227-231

WADE, J.A. and MacLean, B.C. 1990. The geology of the southeastern margin of Canada, Part 2: Aspects of the geology of the Scotian Basin from recent seismic and well data. In Geology of the continental margin of eastern Canada. Edited by M.J. Keen and G.L. Williams. Geological Survey of Canada, Geology of Canada No. 2, pp. 190-238 (also Geological Society of America, The Geology of North America, I-1).

WebB, G.W. 1969. Paleozoic wrench faults in Canadian Appalachians. In North Atlantic Geology and Continental Drift. Edited by M. Kay. American Association of Petroleum Geologists, Memoir 12, pp. 754-786.

Williams, G.L., Fyffe, L.R., Wardle, R.J., Colman-Sadd, S.P., and BozhNer, R.C. 1985. Lexicon of Canadian Stratigraphy, Volume VI, Atlantic Region. Canadian Society of Petroleum Geologists, 572 p.

Williams, H. 1979. Appalachian Orogen in Canada. Canadian Journal of Earth Sciences, 16, pp. 792-807.

Williams, H. and HatcheR, R.D., JR. 1982. Suspect terranes and accretionay history of the Appalachian Orogen. Geology, 10, pp. 530-536.

--.- 1983. Appalachian suspect terranes. Geological Society of America, Memoir 158, pp. 33-53.

Withiack, M.O., Olsen, P.E., and Link, M.H. 1992. Rifting and inversion in the Bay of Fundy, Canada: A seismic perspective. Abstract, EOS Transactions, American Geophysical Union, 73 , p. 563.

Withinck, M.O., Olsen, P.E., and Schlische, R.W. 1995. Tectonic evolution of the Fundy rift basin, Canada: evidence of extension and shortening during passive margin development. Tectonics, 14, pp. 390-405.

WITTE, W.K., KENT, D.V., and OLSEN, P.E. 1991. Magnetostratigraphy and paleomagnetic poles from Late Triassic-earliest Jurassic strata of the Newark Basin. Geological Society of America, Bulletin 103, pp. 1648-1662.

WRIGHT, W.J. and Clements, C.S. 1943. Coal deposits of LepreauMusquash district, New Brunswick. Acadian Naturalist, 1, pp. 5-27.

ZIEGLER, D.G. 1983. Hydrocarbon potential of the Newark Rift System: Eastern North America. Text of paper presented to American Association of Petroleum Geologists Meeting, Dallas, Texas, April 19, 1983. 